\title{
Renewable Energy Opportunities at the Kanto Installations, Japan
}
AE Solana
JA Horner
WJ Gorrissen
JR Hand
BJ Russo
AR Kora
AC Orrell
MR Weimar
JL Williamson

August 2010

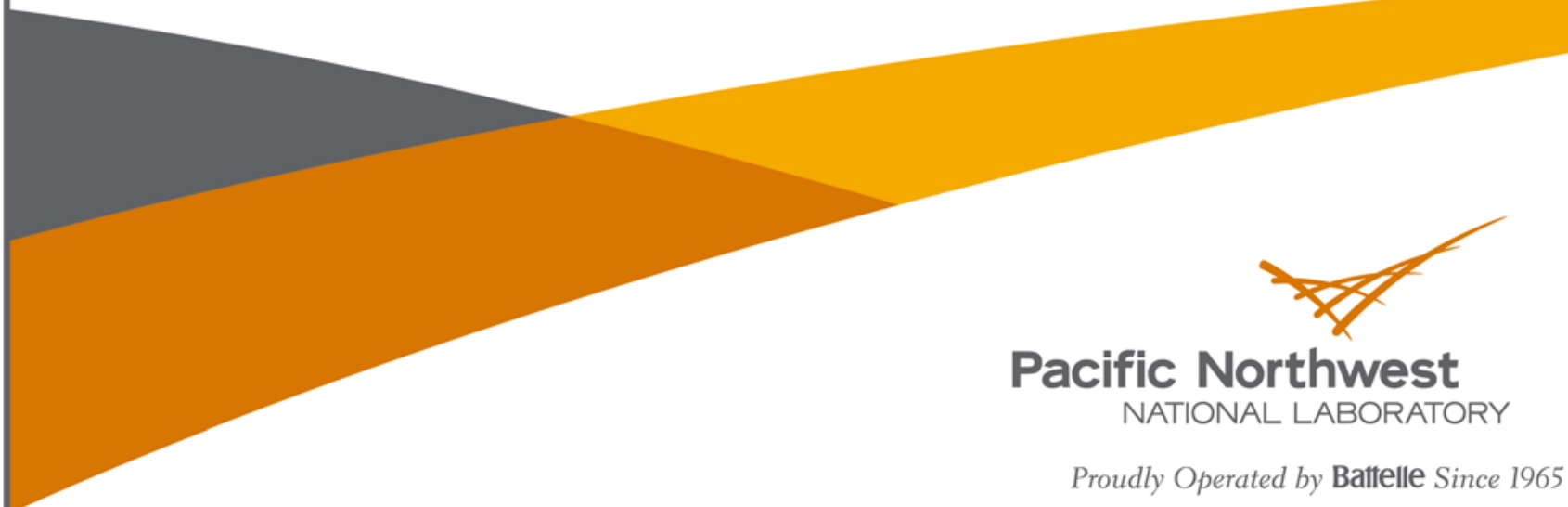




\title{
DISCLAIMER
}

This report was prepared as an account of work sponsored by an agency of the United States Government. Neither the United States Government nor any agency thereof, nor Battelle Memorial Institute, nor any of their employees, makes any warranty, express or implied, or assumes any legal liability or responsibility for the accuracy, completeness, or usefulness of any information, apparatus, product, or process disclosed, or represents that its use would not infringe privately owned rights. Reference herein to any specific commercial product, process, or service by trade name, trademark, manufacturer, or otherwise does not necessarily constitute or imply its endorsement, recommendation, or favoring by the United States Government or any agency thereof, or Battelle Memorial Institute. The views and opinions of authors expressed herein do not necessarily state or reflect those of the United States Government or any agency thereof.

\author{
PACIFIC NORTHWEST NATIONAL LABORATORY \\ operated by \\ BATTELLE \\ for the \\ UNITED STATES DEPARTMENT OF ENERGY \\ under Contract DE-AC05-76RL01830 \\ Printed in the United States of America \\ Available to DOE and DOE contractors from the \\ Office of Scientific and Technical Information, \\ P.O. Box 62, Oak Ridge, TN 37831-0062; \\ ph: (865) 576-8401 \\ fax: $(865) 576-5728$ \\ email: reports@adonis.osti.gov \\ Available to the public from the National Technical Information Service, \\ U.S. Department of Commerce, 5285 Port Royal Rd., Springfield, VA 22161 \\ ph: (800) 553-6847 \\ fax: (703) 605-6900 \\ email: orders@ntis.fedworld.gov \\ online ordering: http://www.ntis.gov/ordering.htm
}




\section{Renewable Energy Opportunities at the Kanto Installations, Japan}

$\begin{array}{lll}\text { AE Solana } & \text { WJ Gorrissen } & \text { JR Hand } \\ \text { JA Horner } & \text { AR Kora } & \text { AC Orrell } \\ \text { BJ Russo } & \text { MR Weimar } & \text { JL Williamson }\end{array}$

August 2010

Prepared for

Office of the Assistant Secretary of the Army

for Installations and Environment

under Contract DE-AC05-76RL01830

Pacific Northwest National Laboratory

Richland, Washington 99352 



\section{Executive Summary}

This document provides an overview of renewable resource development potential at the U.S. Army installations in the Kanto region in Japan, which includes Camp Zama, Yokohama North Dock, Sagamihara Family Housing Area (SFHA), Sagami General Depot, and Akasaka Press Center. This effort focuses on grid-connected generation of electricity from renewable energy sources and also on ground source heat pumps for heating and cooling buildings. The effort was funded by the Huntsville Army Corps of Engineers, and includes the development of a methodology for renewable resource assessment at Army installations located on foreign soil. The methodology is documented in Renewable Energy Assessment Methodology for Japanese OCONUS Army Installations. The site visit to the Kanto installations took place on April 5 and 6, 2010.

At the current time, there are some renewable technologies that show economic potential. Because of siting restrictions and the small size of these installations, development of most renewable energy technologies will likely be limited to Camp Zama. Project feasibility is based on installation-specific resource availability and energy costs and projections based on accepted life-cycle cost methods.

Development of any renewable energy project will be challenging, as it will require investigation into existing contractual obligations, new contracts that could be developed, the legality of certain partnerships, and available financing avenues, which involves the U.S. Forces Japan (USFJ), the Government of Japan (GOJ), and a number of other parties on both sides. The Army will not be able to implement a project without involvement and approval from the other services and multiple levels of Japanese government. However, implementation of renewable energy projects could be an attractive method for GOJ to reduce greenhouse gas emissions and lower annual utility payments to USFJ.

This report recommends projects to pursue and offers approaches to use. The most promising opportunities include waste-to-energy and ground source heat pumps. Solar photovoltaics (PV) may also prove successful. Other resources were found to be insufficient on the Kanto installations.

\section{Waste-to-Energy}

Camp Zama operates an incinerator onsite strictly for disposal of portions of waste from Camp Zama, Sagami General Depot, and SFHA. The incinerator is currently past its life expectancy and uses outdated emissions control equipment. Construction of a new waste-to-energy facility to process this waste is not economic, but retrofitting the existing incinerator to generate energy may be. A maximum total capital cost of about $¥ 233.4$ million $^{1}(500 \mathrm{~kW}$ at $¥ 466,800 / \mathrm{kW}$ ) would be needed for an economic conversion. Alternatively, Camp Zama could explore the possibility of sending waste to the new offsite incinerator and counting an equivalent amount of generated electricity (delivered through the utility) as renewable energy.

\footnotetext{
${ }^{1}$ Assuming $\$ 1=¥ 100$
} 


\section{Ground Source Heat Pumps}

Open-loop, horizontal closed-loop, and vertical closed-loop ground source heat pump configurations were all found to be cost-effective at various locations and buildings on the Kanto installations. Land availability needs to be investigated, but Camp Zama may be the only installation with sufficient space for the heat exchange loops. Ground source heat pumps were analyzed using the Facility Energy Decision System (FEDS) building energy model developed for a 2009 energy efficiency assessment. Simple paybacks range from 4.6 to 21.2 years for appropriated funding, which is probably the only funding source available for these retrofit projects.

\section{Solar PV}

Solar PV panels are not economic at this time, but are one of the most practical renewable technologies for the Japan installations with regard to siting and potential for GOJ financing. Depending on the technology, solar PV panels would generate energy at a cost of $¥ 99 / \mathrm{kWh}$ to $¥ 141 / \mathrm{kWh}$, and have a payback of 72 to 115 years. However, $1 \mathrm{MW}$ of solar could save 425,000 to $516,000 \mathrm{~kg}$ of $\mathrm{CO}_{2}$ per year. Discussions with GOJ should include the possibility of a PV project, especially in light of the upcoming renegotiations regarding the Utility Cost Sharing (UCS) program. Furthermore, advances in PV technology are expected to produce less expensive solar cells, and GOJ is working to increase solar PV installations in Japan.

Renewable resources with at least some potential for being implemented are summarized in Table S.1. If a waste-to-energy project is implemented using all waste from the 3 installations, it could provide about 3.723 MWh, or 9\% of Camp Zama's electricity consumption. Ground source heat pumps could save up to 18,362 MMBtu per year. The amount of electricity generated from solar PV depends on the available space for an array; $1 \mathrm{MW}$, requiring about 60,000 square feet of roof space, would generate 958 to 1,162 MWh per year.

Increasing use of renewable energy makes sense for the Army, and they should lead the way to renewable energy development for USFJ. 
Table S.1: Summary of Promising Renewable Energy Projects for the Kanto Installations

\begin{tabular}{|c|c|c|c|c|c|c|c|c|c|}
\hline & \begin{tabular}{|l|} 
Renewable \\
Resource and \\
Technology \\
\end{tabular} & $\begin{array}{c}\text { Resource } \\
\text { Estimate }\end{array}$ & \begin{tabular}{|l} 
Earliest \\
Output
\end{tabular} & Figures of Merit & & $\begin{array}{l}\text { Financing } \\
\text { Mechanisms } \\
\text { Evaluated }\end{array}$ & $\begin{array}{c}\text { Location } \\
\text { Requirements }\end{array}$ & Key & $\begin{array}{l}\text { Next Steps I } \\
\text { Comments }\end{array}$ \\
\hline 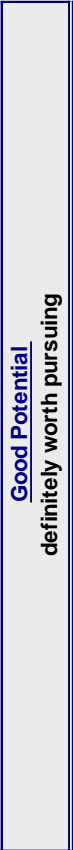 & \begin{tabular}{||c} 
Municipal \\
Waste-to- \\
Energy Plant \\
\\
$---~-~-~$ \\
Ground Source \\
Heat Pump \\
(Thermal \\
Energy)
\end{tabular} & 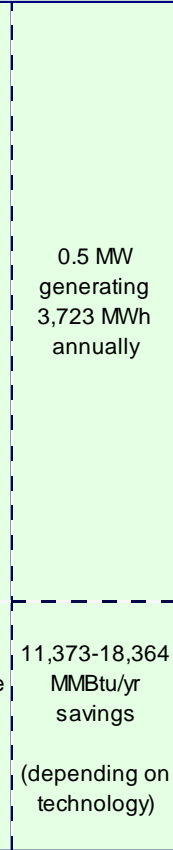 & 2012 & $\begin{array}{l}\text { For retrofit plant: } \\
¥ 466,800 / \mathrm{kW} \text { total } \\
\text { capital cost } \\
\text { required for } \\
\text { economic plant. } \\
\text { For new plant: } \\
\text { ECIP scenario: } 0.1 \\
\text { SIR, } 67 \text { year } \\
\text { payback at } \\
¥ 13.57 / \mathrm{kWh} \\
\text { IPP scenario: } \\
¥ 26.9 / \mathrm{kWh} \text { at } 10 \% \\
\text { IRR } \\
\\
\text { - - - - - - } \\
\text { ECIP scenario: } 4.6 \text { - } \\
21.2 \text { year payback } \\
\text { UESC/ESPC } \\
\text { scenario: } 5.1-25.8 \\
\text { year payback }\end{array}$ & $\begin{array}{l}1 \\
1 \\
1 \\
1\end{array}$ & $\begin{array}{l}\text { ECIP } \\
\text { IPP }\end{array}$ & $\begin{array}{l}\text { I } \\
\text { I } \\
\text { I (retrofit or replaced), } \\
\text { I plus feedstock } \\
\text { I storage space and } \\
\text { I utility interconnection. } \\
\text { I } \\
\text { I } \\
\text { I } \\
\text { I } \\
\text { I } \\
\text { I } \\
\text { I_ - - - - - - - } \\
\text { I } \\
\text { I Space near buildings } \\
\text { for heat exchange } \\
\text { I wells or loop. } \\
\text { I } \\
\text { I }\end{array}$ & $\begin{array}{l}\text { Existing incinerator can } \\
\text { be expanded and retrofit } \\
\text { with energy generation } \\
\text { equipment for less than } \\
¥ 466,800 / \mathrm{kW} \text {. MSW from } \\
\text { SFHA and Sagami Depot } \\
\text { can be transported to } \\
\text { and used on Camp } \\
\text { Zama. } \\
\text { IECIP funding will be } \\
\text { awarded to fund GSHP } \\
\text { projects; other funding is } \\
\text { Inot available. }\end{array}$ & 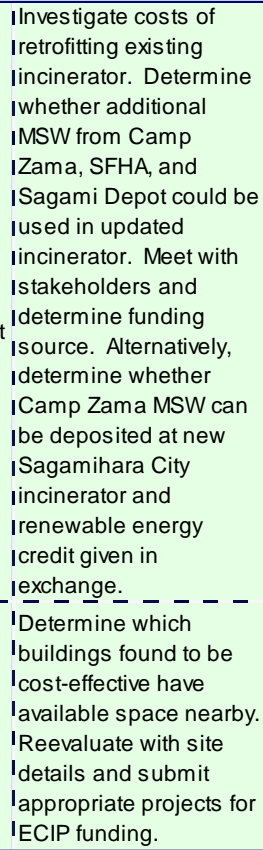 \\
\hline 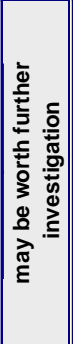 & $\begin{array}{l}\text { Utility-Grade } \\
\text { Solar Electric } \\
\text { Power Plant }\end{array}$ & $\begin{array}{l}\text { I } \\
\text { I } 1.0 \mathrm{MW} \\
\text { I generating } 958 \\
\text { I,162 MWh } \\
\text { annually } \\
\text { I (depending on } \\
\text { I technology) } \\
\end{array}$ & 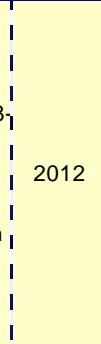 & $\begin{array}{c}\text { ECIP scenario: } 0.12 \\
0.19 \text { SIR, } 72-115 \\
\text { year payback at } \\
¥ 12.0 / \mathrm{kWh} \\
\text { IPP scenario: } ¥ 99.4 \\
140.9 / \mathrm{kWh} \text { at } 10 \% \\
\text { IRR } \\
\text { (depending on } \\
\text { technology) }\end{array}$ & & $\begin{array}{l}\text { ECIP } \\
\text { IPP }\end{array}$ & $\begin{array}{l}\text { IRooftops, especially } \\
\text { I where replacing } \\
\text { I } \text { roofs. Also open } \\
\text { Iground area near } \\
\text { I high-voltage power } \\
\text { I lines, away from } \\
\text { I obstruction by } \\
\text { I shadows or danger of } \\
\text { I vandalism. } \\
\text { I }\end{array}$ & $\begin{array}{l}\text { Incentives are not } \\
\text { available for a PV project } \\
\text { on Army land. }\end{array}$ & $\begin{array}{l}\text { Monitor market } \\
\text { conditions for decrease } \\
\text { in PV system costs. } \\
\text { Discuss PV system } \\
\text { development with GOJ } \\
\text { as part of UCS } \\
\text { renegotiation. }\end{array}$ \\
\hline
\end{tabular}

ECIP = Energy Conservation Investment Program

SIR = savings-to-investment ratio

IPP = independent power producer

UESC = Utility Energy Services Contract

ESPC = Energy Savings Performance Contract

MSW = municipal solid waste

GSHP = ground source heat pump 


\section{Table of Contents}

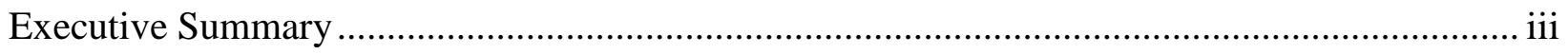

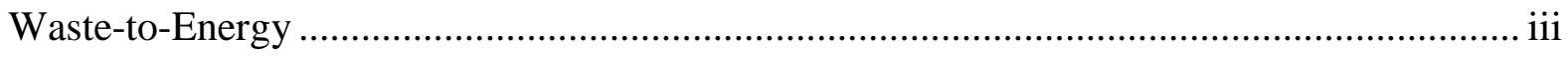

Ground Source Heat Pumps ......................................................................................... iv

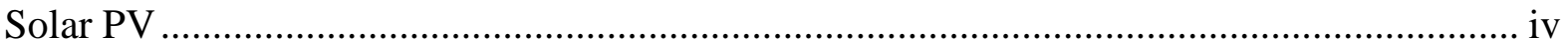

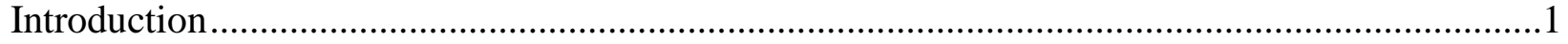

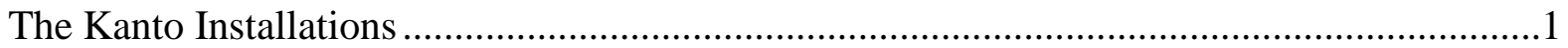

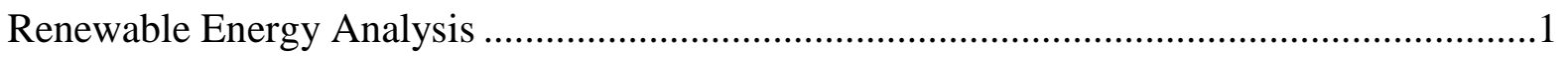

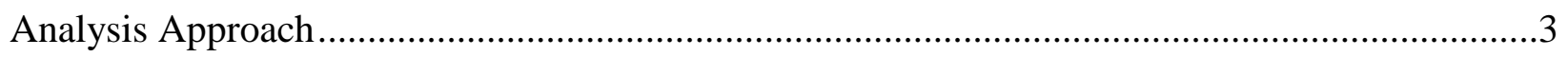

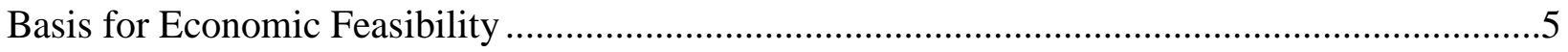

Kanto Installations Energy Characterization ....................................................................5

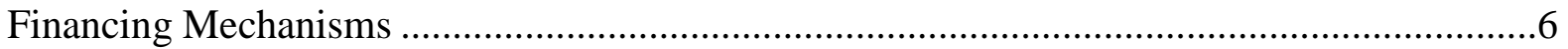

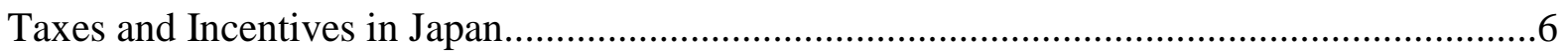

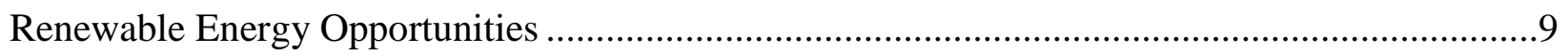

Waste-to-Energy Findings and Recommendations..........................................................

Ground Source Heat Pump Findings and Recommendations............................................13

Solar Energy Findings and Recommendations .........................................................14

Geothermal Power Plant Findings and Recommendations................................................15

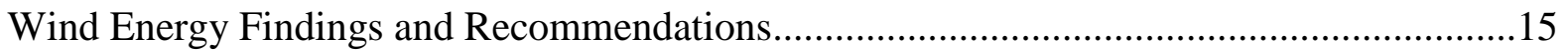

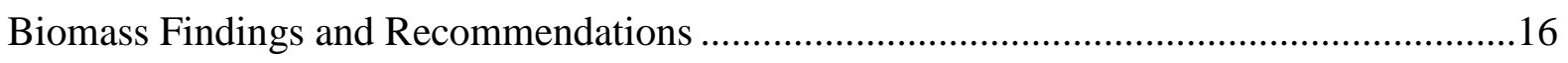

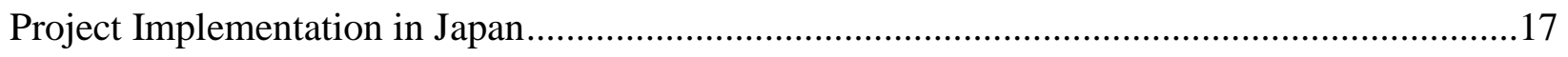

Policies, Standards, and Regulatory Structure ............................................................17

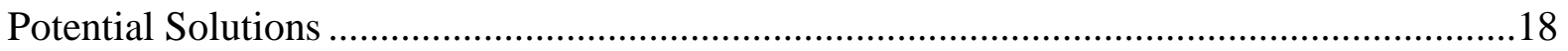

Appendix A: Analysis of Solar Opportunities .................................................................. A-1

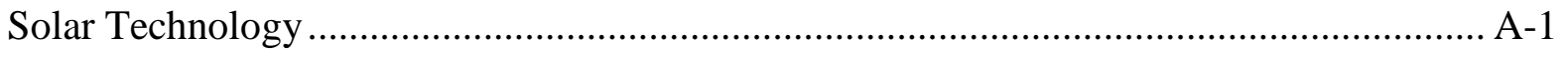

Solar Electric Technologies ........................................................................ A-1

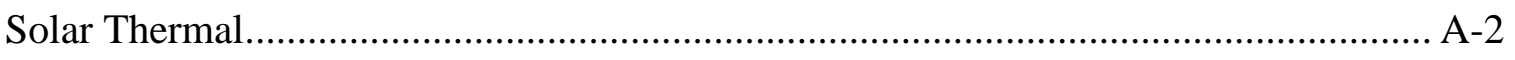

Solar Analysis Approach .................................................................................... A-2

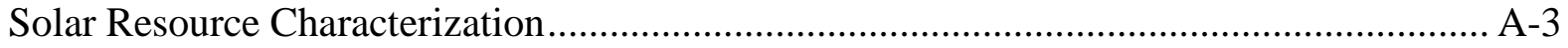

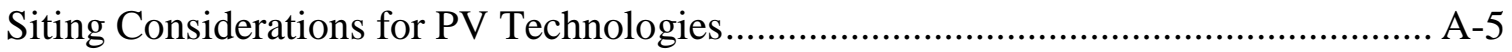

Findings: Solar Electric Production ........................................................................ A -5 
Findings: Solar Project Economics ............................................................................. A-6

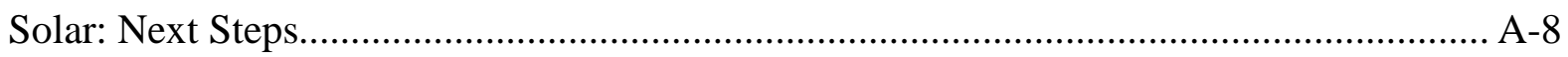

Solar Sources of Information ..................................................................................... A-

Appendix B: Analysis of Wind Opportunities......................................................................

Wind Technology ………………………………….....................................................

Wind Analysis Approach............................................................................................

Wind Resource Characterization ......................................................................................

Siting Considerations …………………………………................................................

Yokohama Wind Turbine ..............................................................................................

Wind: Economic and Other Analysis Parameters...................................................................

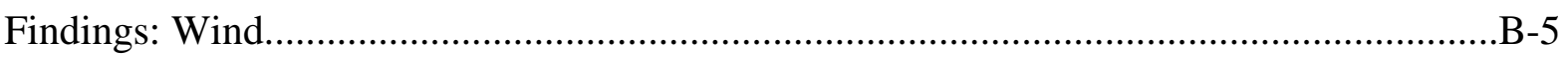

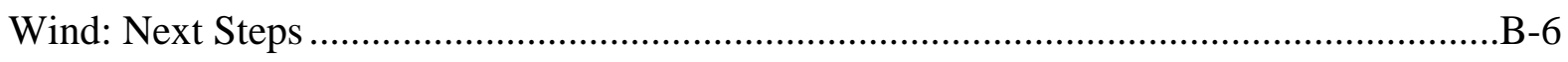

Wind Sources of Information..............................................................................................

Appendix C: Analysis of Biomass and Waste-to-Energy Opportunities ........................................

Biomass and Waste-to-Energy Technology .............................................................................

Siting Considerations .......................................................................................................

Biomass and Waste-to-Energy Analysis Approach ................................................................

Biomass and Waste Resource Characterization........................................................................

Agricultural Biomass ……………………………………..........................................

Forest Thinnings and Logging Slash ...............................................................................

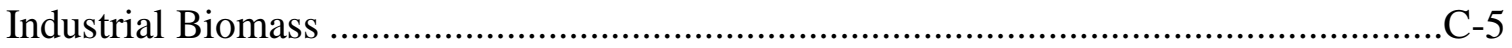

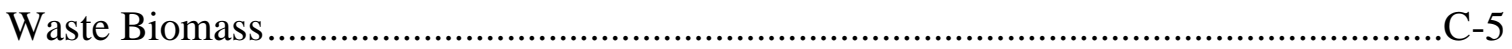

Biomass and Waste-to-Energy: Economic and Other Analysis Parameters..............................-7

Findings: Biomass and Waste-to-Energy Opportunities.........................................................

Biomass and Waste-to-Energy: Next Steps …………………………………………….......

Biomass and Waste-to-Energy Sources of Information............................................................

Appendix D: Analysis of Geothermal Power Plant Opportunities ........................................... D-1

Geothermal Power Technology ………………………............................................... D-1

Geothermal Power Analysis Approach............................................................................ D-1

Geothermal Power Resource Characterization ………………………………………....... D-2

Geothermal Power: Economic and Other Analysis Parameters ………………………....... D-3

Findings: Geothermal Power …………………………….................................................. D-4 


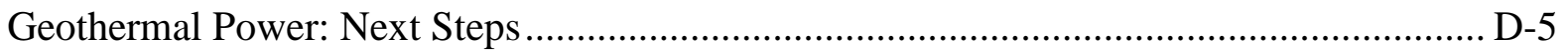

Geothermal Power Sources of Information ..................................................................... D-5

Appendix E: Analysis of Ground Source Heat Pump Opportunities.......................................E-1

Ground Source Heat Pump Technology .......................................................................... E-1

Ground Source Heat Pump Analysis Approach.................................................................E-2

Ground Source Heat Pump Resource Characterization ...................................................E-6

Ground Source Heat Pumps: Economic and Other Analysis Parameters.............................. E-7

Findings: Ground Source Heat Pumps..........................................................................E-8

Ground Source Heat Pumps: Next Steps …....................................................................E-11

Ground Source Heat Pump Sources of Information ....................................................E-12

Appendix E.1: Detailed GSHP Economic Results ........................................................... $1-1$ 


\section{Figures}

Figure 1: The Kanto Installations ................................................................................. 2

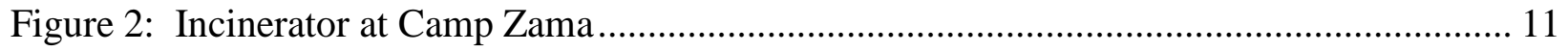

Figure A.1: Axis-Tracking PV Array ........................................................................ A-2

Figure A.2: Solar Insolation Levels (Tsuna-san 2008) ................................................... A-3

Figure A.3: Average Daily Insolation at the Kanto Installations (NASA 2010) ..................... A-5

Figure B.1: Average Wind Speeds at Camp Zama and Yokohama North Dock.......................B-3

Figure D.1: Boreholes and Well Data near the Kanto Installations...................................... D-3 


\section{Tables}

Table S.1: Summary of Promising Renewable Energy Projects for the Kanto Installations......... v

Table 1: Summary of Known Electric Usage and Rates Information ...................................... 5

Table 2: Taxes Used in Analysis ......................................................................................... 7

Table 3: Summary of Renewable Energy Opportunities at the Kanto Installations ................... 10

Table 4: Results for a New WTE Plant at Camp Zama .......................................................... 12

Table 5: Simple Payback and Savings for GSHPs at Kanto Installations ............................... 13

Table 6: Solar Resource and Economic Results at the Kanto Installations .............................. 15

Table 7: Economic Assessment of Geothermal Power............................................................ 15

Table 8: Economic Assessment of Wind Power ................................................................. 16

Table A.1: Monthly Averaged Insolation at the Kanto Installations (kWh/m²/day) ............... A-4

Table A.2: Solar Electric Production by System Type at the Kanto Installations .................... A-6

Table A.3: Economic Results for Solar Technologies at the Kanto Installations..................... A-7

Table B.1: Classes of Wind Power Density at 50 m.............................................................2

Table B.2: Summary of Wind Resource Data .......................................................................

Table B.3: Performance, Cost, and Economic Characteristics ..................................................5

Table B.4: Economic Assessment of Wind Power ..............................................................6

Table C.1: Waste Generated at Kanto Installations .................................................................5

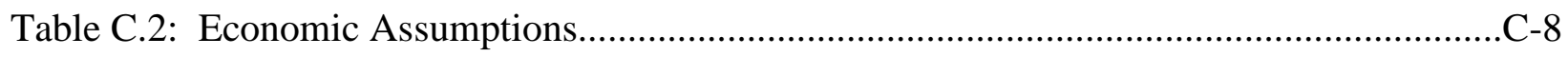

Table C.3: Results for a New WTE Plant at Camp Zama ......................................................9

Table D.1: Performance, Cost, and Economic Characteristics .......................................... D-4

Table D.2: Economic Assessment of Geothermal Power ................................................. D-5

Table E.1: Building Groups Analyzed in FEDS for GSHPs ..................................................3

Table E.2: Buildings Analyzed in FEDS for GSHPs.............................................................6

Table E.3: Simple Payback Period for Building Groups Analyzed in FEDS for GSHPs ........E-10

Table E.4: Total $\mathrm{CO}_{2}$ Reductions for GSHP Retrofits (tons $\mathrm{CO}_{2}$ per year) ............................ E-11 


\section{Introduction}

Pacific Northwest National Laboratory (PNNL) has been directed by the Huntsville Army Corps of Engineers to conduct detailed analyses of the potential for electricity generation at selected U.S. Army installations located in Japan. The analysis is documented in two reports, the Renewable Energy Assessment Methodology for Japanese OCONUS Army Installations ("Methodology Report”), and this results report. This report focuses on the Kanto installations, including Camp Zama, Yokohama North Dock (ND), Sagamihara Family Housing Area (SFHA), Akasaka Press Center (PC), and Sagami General Depot (Sagami Depot).

\section{The Kanto Installations}

Camp Zama is the principle U.S. Army installation in Japan. It lies about 25 miles southwest of Tokyo and is the home of the U.S. Army Japan's (USAJ) I Corps (Forward) and several smaller brigades and battalions, including the Corp of Engineers. Historically, Camp Zama was the Imperial Japanese Army Academy. The four smaller, specialized installations near Camp Zama are all under the command of U.S. Army Garrison Commander at Camp Zama. All five installations are shown on the map in Figure 1.

Yokohama ND, located on a man-made island in Yokohama Bay, has served as a pier for Army troop vessels visiting or deploying in the Tokyo area, but is now used mainly for storage with only a small caretaker staff of about 40 trades people, plus support staff.

SFHA, located about 5 km (3 miles) from Camp Zama, provides on-base housing for Camp Zama families as well as a few basic services and schools.

The Akasaka PC is located in downtown Tokyo and, in addition to liaison with Japan's press, prints the Army newspaper, “The Stars and Stripes.” The entire installation consists of the newsprint operation building and a helipad, and employs about 20 people.

Sagami Depot stores forward-based munitions and petroleum. The installation consists of storage bunkers and support facilities.

\section{Renewable Energy Analysis}

As stated in the Methodology Report, the goal of the analysis is to identify economically feasible opportunities for generation of electricity from renewable resources to contribute in a meaningful way to the aggressive renewable energy goals of the Army and the Department of Defense (DoD). Furthermore, the challenges of implementing renewable energy generation projects in Japan needed to be identified and taken into consideration.

Renewable energy resources analyzed include solar, wind, biomass, waste-to-energy (WTE), geothermal, and ground source heat pumps (GSHPs). The Methodology Report outlined the approach to be taken for this analysis, including how to quantify each resource and how to determine project economics. It also gave an overview of the political and economic environment for renewables in Japan. This report documents the findings of the analysis and the recommendations for project implementation. 
The overall assumptions and findings of this analysis are summarized in the main body of the report. Appendix A describes the solar analysis. Appendix B describes the wind energy analysis. Appendix C describes the analysis conducted on biomass and waste-to-energy technologies. Appendix D describes the geothermal analysis, and Appendix E, the GSHP analysis.

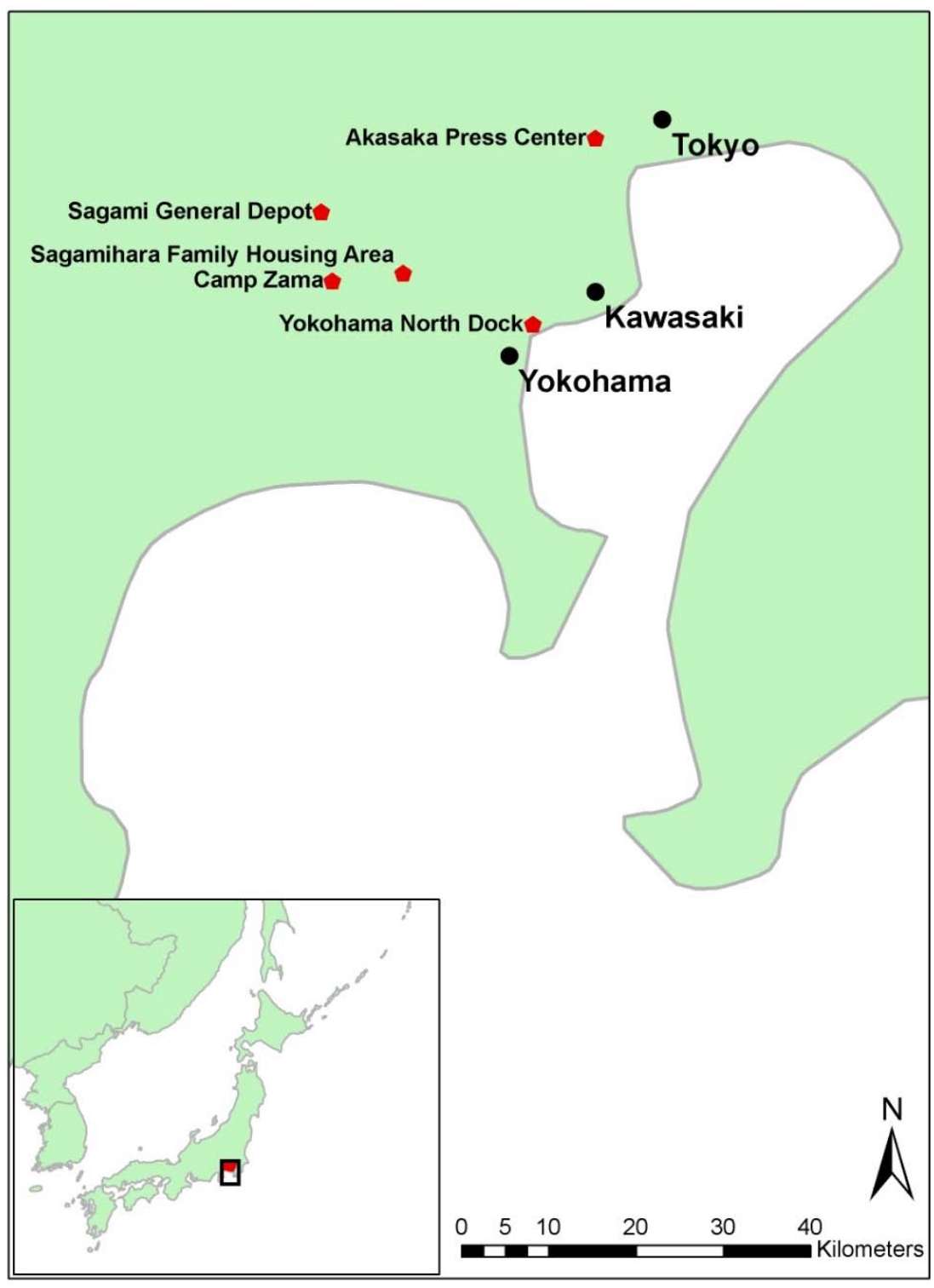

Figure 1: The Kanto Installations 


\section{Analys is Approach}

Ron Nesse and Amy Solana from PNNL visited Camp Zama, Yokohama ND, and SFHA in Kanto, Japan on April 5 and 6, 2010. Akasaka PC and Sagami Depot are small installations with minimal energy consumption, and so were not visited during this trip. Jeff Molony, the energy manager at Camp Zama, hosted PNNL and provided site tours and analysis data.

An in-brief was held at Camp Zama on April 5, with the following Camp Zama personnel in attendance.

- Jeffrey Molony, Environmental Engineer

- Felix Mariani, Director of Public Works

- Masafumi Akamatsu, Department of Public Works (DPW)

- Hideyuki Ueno, DPW

- Masaaki Kataoka, DPW

- Shigeru Akata, DPW

- Brian Whang, DPW

- David Magnuson, DPW

- George Moreck, DPW

- Masanobu Maejima, DPW

- Kazuhiro Fukui, DPW

- David Yin, DPW

- Henry Calhoun, DPW Housing Division

- Michael Fies, Japan Engineering District (JED)/Programs and Project Management Division

- Frank Niimi, Chief of Electrical and Air Conditioning Branch

- Hideaki Yagi, Master Planning/Planning Branch

- Kikuo Tanaka, Master Planning

- Hidemi Takagi, Program Analyst, Environmental Division

Wayne Le Bleu, Chief of Akizuki Sub-Facilities Engineering, and Henry Nwe, Chief of Engineering at Torii Station, participated via telephone to represent the other main areas of U.S. Army installations in Japan.

The in-brief included an explanation of the assessment process and preliminary assessment results. The goal was to stimulate conversation among participants about implementation methods and project ideas. It became apparent that there is no clear path forward for renewable energy development because no renewable energy projects currently exist on U.S. Army land in Japan. Documentation of implementation challenges and hurdles, therefore, is an important step in this assessment process.

The remainder of the assessment visit consisted of meetings with personnel in various positions to discuss their views on potential paths forward, touring the installations to better understand siting and energy issues, and collecting additional data for a more detailed analysis. With this additional information, the resource and economic analyses were refined to enable informed recommendations. 
Renewable Energy Opportunities at the Kanto Installations, Japan Pacific Northwest National Laboratory, August 2010 


\section{Bas is for Economic Feasibility}

The renewable projects considered in this analysis need to compare favorably against the commercial price of electricity purchased by each installation to be economically feasible. Current costs of electricity, financing methods, and taxes and incentives all play a role in the cost comparison. An exchange rate of $\$ 1=¥ 100$ is used for this analysis.

\section{Kanto Installations Energy Characterization}

The Kanto installations are located in the Tokyo Electric Power Company (TEPCO) service territory. TEPCO provides electricity to each installation through a separate contract and rate schedule, although they follow the same basic structure. Electricity is billed based on a demand charge and time-of-use consumption charges. The summer season is from July 1 to September 30. Peak times are 1300 to 1600; daytime is from 0800 to 1300 and 1600 to 2200. Other season daytimes occur from 0800 to 2200, October through June. Nighttime charges occur during nights, Sundays, and holidays. Table 1 shows each installation's electricity usage and billing data.

Table 1: Summary of Known Electric Usage and Rates Information

\begin{tabular}{||l|c|c|c||}
\hline Installation & Camp Zama & SFHA & Sagami Depot \\
\hline FY09 Consumption (MWh) & 40,040 & 9,081 & 10,044 \\
\hline FY09 Electricity Cost (¥) & $¥ 544,498,843$ & $¥ 132,022,815$ & $¥ 154,584,886$ \\
\hline FY09 Average Demand (MW) & 4.6 & 1.0 & 1.1 \\
\hline FY09 Peak Demand (MW) & 8.7 & 1.7 & 2.5 \\
\hline Month of Peak Demand & August & January & August \\
\hline Demand Charge (¥/kW) & $¥ 1,533$ & $¥ 1,638$ & $¥ 1,533$ \\
\hline $\begin{array}{l}\text { Summer Peak Consumption } \\
\text { Charge (¥/kWh) }\end{array}$ & $¥ 13.75$ & $¥ 16.60$ & $¥ 13.75$ \\
\hline $\begin{array}{l}\text { Summer Daytime Consumption } \\
\text { Charge (¥/kWh) }\end{array}$ & $¥ 13.17$ & $¥ 15.92$ & $¥ 13.17$ (¥11.47 \\
\hline $\begin{array}{l}\text { Other Season Daytime Charge } \\
\text { (¥/kWh) }\end{array}$ & $¥ 12.07$ & $¥ 14.56$ & $¥ 12.07$ (¥10.59 \\
\hline \begin{tabular}{l} 
Nighttime Charge (¥/kWh) \\
\hline
\end{tabular} & $¥ 8.81$ & $¥ 9.20$ & $¥ 8.81$ \\
\hline
\end{tabular}

Limited information was available for Yokohama ND, and no information was available for Akasaka PC. Yokohama ND has a load of about 200-300 kW, but has a contract demand of $500 \mathrm{~kW}$. The Navy's nearby cold storage building, which consumes about $800 \mathrm{~kW}$, was on Yokohama's meter, but will be removed, leaving Yokohama with a smaller load than the electric contract requires. A new customer must be found. Akasaka PC contains only one building and therefore contributes a negligible amount of energy and cost to the total bill for the Kanto installations.

Camp Zama consumes $2 / 3$ of the electricity consumption for the area installations, has the most potential for a feasible location for a renewable energy project, and has similar costs to the other installations where costs are known. Therefore, only Camp Zama rates were used for the renewable energy economic analysis at all installations. 
Using the blended electricity rate as the displacement cost will lead to inaccurate results when the renewable resource is intermittent (like wind and solar) because intermittent resources cannot be guaranteed to reduce peak demand. Even non-intermittent resources may not result in reduced peak demand because of periodic maintenance shutdowns and unscheduled outages. The economic analyses in this report use only the energy component of the power bill to evaluate intermittent resources, which is admittedly conservative. The blended rate is used for economic analysis of base-load resources.

Solar energy would replace daytime consumption charges only, so a direct energy rate of $¥ 12.0 / \mathrm{kWh}$ was used for solar analysis, and $¥ 9.87 / \mathrm{kWh}$ was used for wind. Biomass and geothermal projects were assumed to replace energy costing an average of $¥ 13.57 / \mathrm{kWh}$. The GSHP analysis used the detailed time-of-use rate schedule to calculate operational cost savings.

\section{Financing Mechanisms}

Financing a renewable energy project in Japan may be one of the biggest hurdles for project implementation. As described in the Methodology Report, this analysis considers two primary sources of funds: third-party financing and Energy Conservation Investment Program (ECIP) funding (appropriated funding). Under the third-party arrangement, power is sold through a contract that is commonly called a power purchase agreement (PPA). Both are applicable to the U.S. installations in Japan, but the options for use of either method are narrowed by the existing agreements between USFJ and GOJ.

The large projects analyzed typically exceed any realistic expectation for appropriated funding, and so commercial (third-party) development of projects is expected. In Japan, the third party will likely be the GOJ because of contracting issues and political agreements. Because essentially no incentives are available for renewable energy projects in Japan, the elimination of an independent power producer (IPP) does not change the assumptions or results of this scenario, and it remains one of the recommended financing methods. It does, however, potentially limit the amount of funds assumed available and therefore the size or number of projects likely to be developed.

In addition, according to the Facility Improvement Program (FIP), new facilities must be funded by GOJ, while retrofits are funded with U.S. funds. It is unclear whether energy generation facilities fall into the "new facility" category, but this requirement is likely to further limit the options for funding projects.

As described in the methodology, economic feasibility for the IPP scenario is based on meeting a $10 \%$ internal rate of return with a cost of energy equal to or less than current costs of energy, and economic feasibility for the ECIP scenario is based on obtaining a savings-to-investment ratio (SIR) of 1.0 .

\section{Taxes and Incentives in Japan}

The Methodology report details the taxes in Japan that were included in this analysis. They are summarized in Table 2. 
Table 2: Taxes Used in Analysis

\begin{tabular}{|l|c||}
\hline \multicolumn{1}{|c|}{ Tax } & $\begin{array}{c}\text { Amount Assumed in } \\
\text { Assessment }\end{array}$ \\
\hline National Income Tax & $30 \%$ \\
\hline Inhabitant/Local Income Tax & Ignored \\
\hline Enterprise Income Tax & $7.56 \%$ \\
\hline Additional National Income Taxes & $0.71 \%$ \\
\hline Municipal/Prefecture Income Taxes & $5.3 \%$ \\
\hline Special Local Income Taxes & $4.3 \%$ \\
\hline Consumption Tax & $5 \%$ \\
\hline Ownership Taxes & $1.7 \%$ \\
\hline Total Income Tax & $47.7 \%$ \\
\hline
\end{tabular}

U.S. utilities are subsidized by the Government of Japan (GOJ) through the Utility Cost Sharing (UCS) program, which is part of the Special Measures Agreement between GOJ and the U.S. Forces in Japan (USFJ). The amount of the utility bill subsidized is a fixed sum for FY09 and FY10, but is being renegotiated for FY11. Because GOJ already pays most of the USFJ utility bill, no additional incentives are offered for renewable energy projects built on U.S. land, by either GOJ or the U.S. government. 


\section{Renewable Energy Opportunities}

A summary of analysis results is presented in Table 3, broken down into economic (green), marginal (yellow), or uneconomic (red) projects. The underlying analyses and recommendations for each of these technologies and potential projects are provided in the following subsections.

\section{Waste-to-Energy Findings and Recommendations}

WTE may be an option for generating renewable electricity and reducing greenhouse gas emissions at Camp Zama, while providing a reliable method for waste disposal for Camp Zama, SFHA, and Sagami Depot. Because large-scale construction projects and renewable energy projects have not previously been developed at U.S. Army installations in Japan, a number of questions will have to first be answered before the precise methods of implementation are known. However, if implemented, a WTE project using municipal solid waste (MSW) from Camp Zama, SFHA, and Sagami Depot could provide about 9\% of Camp Zama's current energy use, exceeding the EPAct goal for Camp Zama but not for all Kanto installations. There are no WTE opportunities for Yokohama ND or Akasaka PC because of their small size and isolated locations.

Waste generated near the installations cannot be brought onsite; only U.S. Army waste can be used in an onsite WTE facility. Currently, Camp Zama processes 2,393 tons of waste per year in an onsite incinerator, which could be used to generate 1,963 MWh per year. If all waste generated at the 3 sites within reasonable transport distance of Camp Zama is included (4,854 tons per year), 3,982 MWh could be generated.

A plant this small would not be economic to build, but Camp Zama's existing incinerator (pictured in Figure 2), which is currently past its life expectancy and uses outdated emissions control equipment, could be updated and expanded to include energy generation equipment for a smaller capital cost. Additional information is needed about the existing plant to determine exact project costs and emissions savings, but this option is likely economic. Furthermore, because this would be a retrofit project, it would not encounter the same funding issues that a new plant would. 
Table 3: Summary of Renewable Energy Opportunities at the Kanto Installations

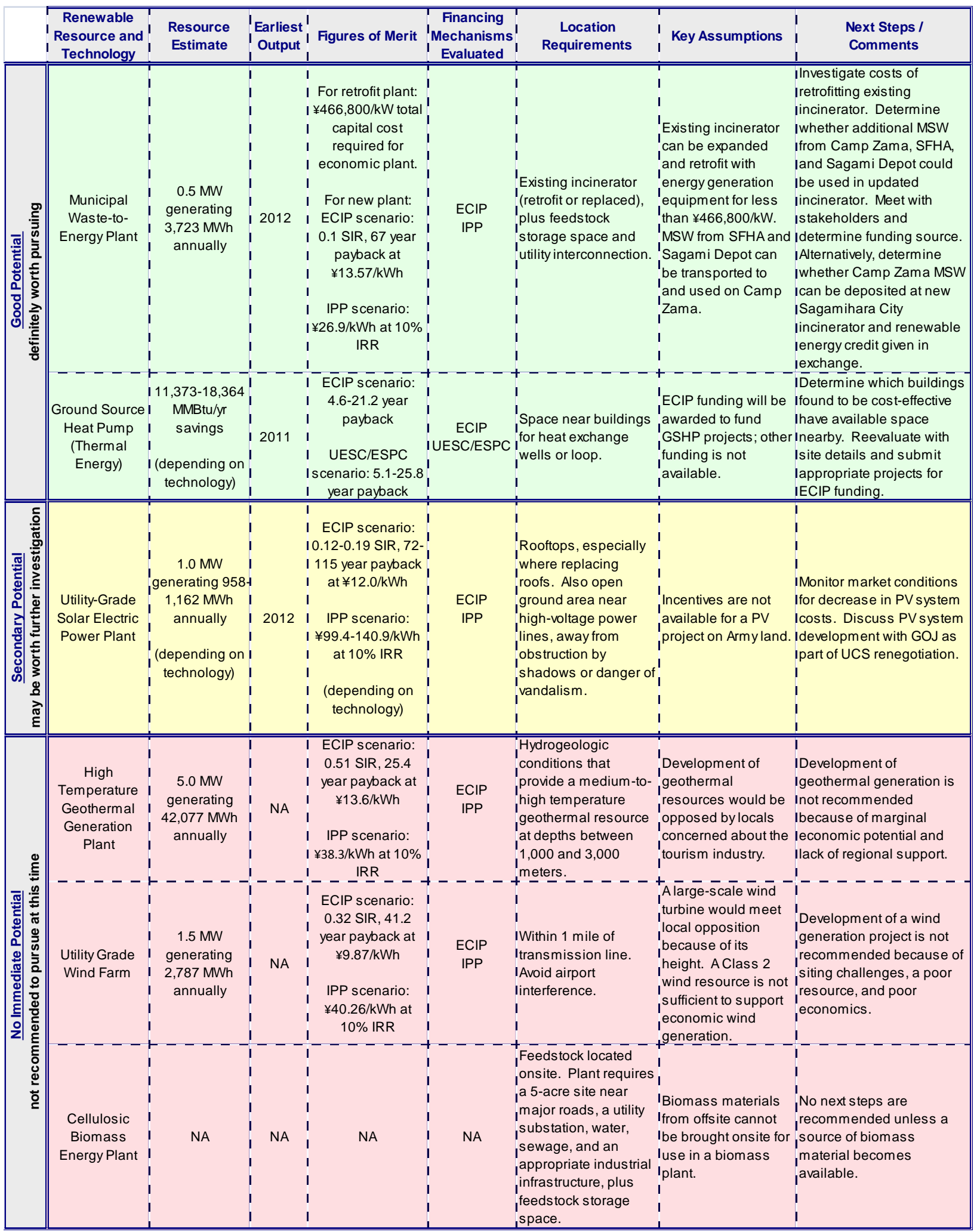




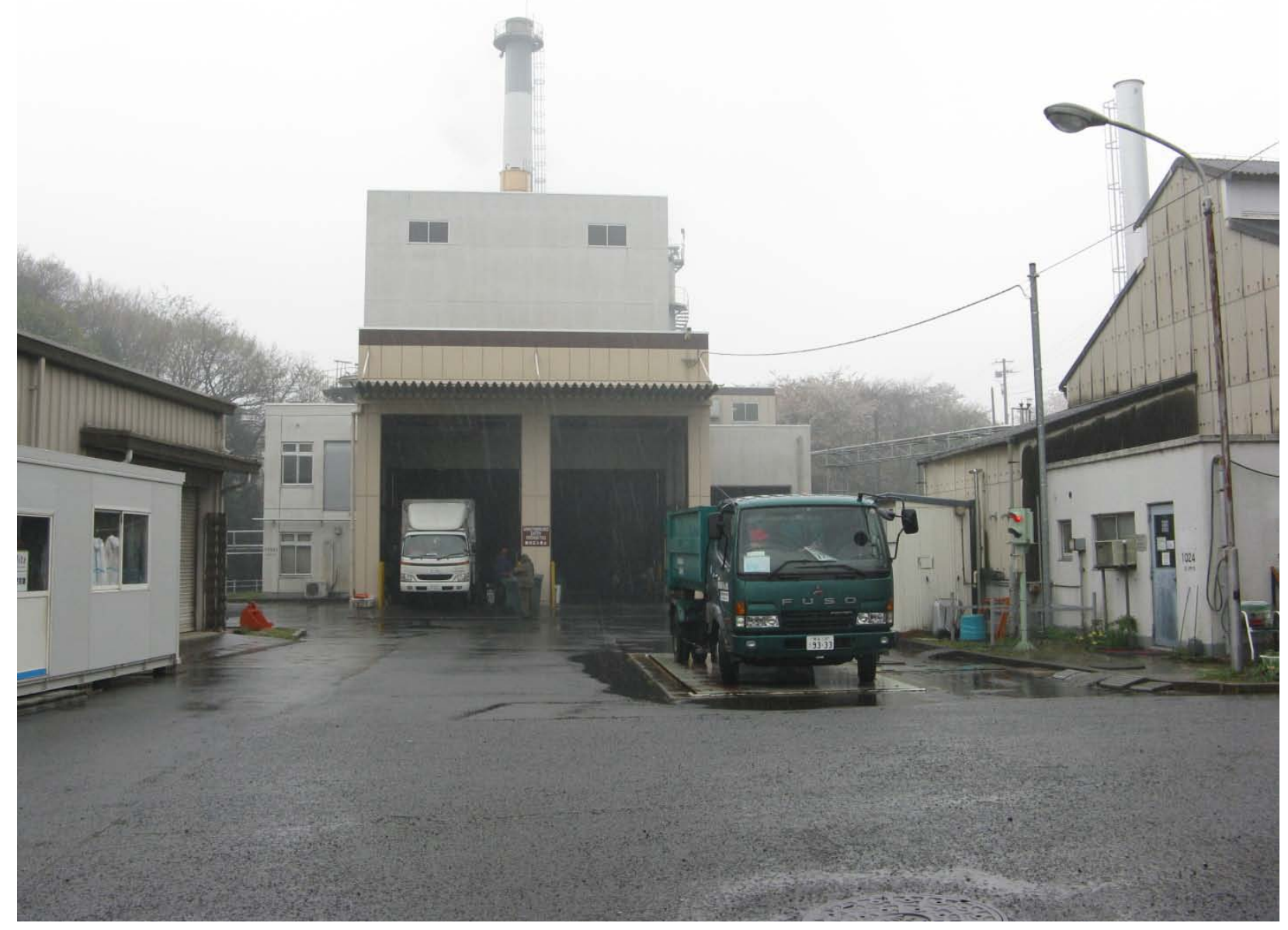

Figure 2: Incinerator at Camp Zama

If the onsite incinerator was converted to a WTE facility and approximately 3,980 MWh/yr was produced onsite rather than purchased from the local utility, annual emissions for Camp Zama could be reduced by a minimum of 1,700 tons of $\mathrm{CO}_{2}$ /year. Furthermore, because converting the onsite incinerator to a WTE facility would include upgrading the emission control equipment, emissions could be further reduced from the amount currently emitted by the incinerator.

Table 4 shows the economic results for a new WTE plant for comparison purposes. A new plant would likely cost about $¥ 644,860 / \mathrm{kW}$; a retrofit to the existing incinerator would need to cost a maximum total of $¥ 466,800 / \mathrm{kW}$ (about $¥ 233.4$ million total) to be economic. 
Table 4: Results for a New WTE Plant at Camp Zama

\begin{tabular}{|l|c|}
\hline \multicolumn{1}{|c|}{ Waste Source } & $\begin{array}{c}\text { Camp Zama, } \\
\text { SFHA, Sagami } \\
\text { Depot }\end{array}$ \\
\hline Technology & Combustion \\
\hline Plant Size & $0.5 \mathrm{MW}$ \\
\hline Feedstock Amount & 4,854 tons/yr \\
\hline Total Plant Cost & $¥ 644,860 / \mathrm{kW}$ \\
\hline \multicolumn{1}{|c|}{ Capital Cost } & $¥ 614,160 / \mathrm{kW}$ \\
\hline \multicolumn{1}{|c|}{ Sales Tax } & $¥ 30,710 / \mathrm{kW}$ \\
\hline Fixed O\&M Cost & $¥ 116,290 / \mathrm{kW}$ \\
\hline Variable O\&M Cost & $-¥ 3.8 / \mathrm{kWh}$ \\
\hline \multicolumn{1}{|c|}{ Feedstock Cost } & $-¥ 4,390 / \mathrm{ton}$ \\
\hline SIR & 0.1 \\
\hline Simple Payback & 67 years \\
\hline $\begin{array}{l}\text { Cost of Electricity at } \\
\text { 10\% Internal Rate of } \\
\text { Return (IRR); No } \\
\text { Financing }\end{array}$ & $¥ 26.9 / \mathrm{kWh}$ \\
\hline
\end{tabular}

Another potential option for renewable energy using MSW would be to send the waste currently incinerated on Camp Zama to the new nearby incinerator owned by Sagamihara City. This incinerator utilizes state-of-the-art WTE technology, and it is theoretically possible that an amount of renewable energy, about 2,020 MWh/year, could be credited to Camp Zama according to the amount of MSW contributed. Shutting the existing incinerator down completely and sending all waste offsite is likely to be advantageous for greenhouse gas emissions and O\&M costs. Camp Zama's contract with TEPCO would have to be renegotiated to include the renewable energy from the incinerator.

It is recommended to further investigate these WTE opportunities. To implement a WTE retrofit project, discussions must be held with stakeholders at Camp Zama, USFJ, GOJ, JED, and TEPCO, as appropriate, to gain support and plan the contracting and funding methods. Further technical and economic analysis is needed with an accurate tonnage of MSW to be used, associated tipping fees, actual capital and operations and maintenance (O\&M) costs, and emissions factors.

To send MSW to the new offsite incinerator and claim renewable energy credit, it must be determined whether Camp Zama's waste will be accepted at the new Sagamihara City incinerator and whether a renewable energy clause could be added to the TEPCO contract.

The benefits and challenges of each of the above options should be considered carefully to identify which option is best for the Kanto installations. Detailed data and results are provided in Appendix C. 


\section{Ground Source Heat Pump Findings and Recommendations}

The cost-effectiveness of retrofitting existing heating, ventilating, and air conditioning (HVAC) systems with GSHPs on the Kanto installations was evaluated using the Facility Energy Decision System (FEDS) building energy modeling program. The FEDS model built for the 2009 energy efficiency analysis was used to assess open-loop, horizontal closed-loop, and vertical closed-loop GSHPs for buildings on all five installations. Both appropriated (ECIP) funding and alternative financing scenarios were analyzed.

GSHPs were found to be economic in some buildings and funding scenarios for all five Kanto installations. Open-loop GSHPs tend to be the most cost-effective because of their low capital cost, but closed-loop GSHPs were also found to be economic for certain building types. The annual energy savings and simple payback range are summarized for each installation, GSHP type, and funding scenario in Table 5.

Table 5: Simple Payback and Savings for GSHPs at Kanto Installations

\begin{tabular}{|c|c|c|c|c|c|}
\hline \multirow[b]{2}{*}{ Installation } & \multirow[b]{2}{*}{ GSHP Type } & \multicolumn{2}{|c|}{ Appropriated Funding } & \multicolumn{2}{|c|}{ Alternative Financing } \\
\hline & & $\begin{array}{c}\text { Simple } \\
\text { Payback } \\
\text { (years) } \\
\end{array}$ & $\begin{array}{c}\text { Energy } \\
\text { Savings } \\
\text { (MMBtu/yr) } \\
\end{array}$ & $\begin{array}{c}\text { Simple } \\
\text { Payback } \\
\text { (years) } \\
\end{array}$ & $\begin{array}{c}\text { Energy } \\
\text { Savings } \\
\text { (MMBtu/yr) }\end{array}$ \\
\hline \multirow{3}{*}{ Akasaka PC } & Open-Loop & 4.6 & 749 & 5.8 & 749 \\
\hline & Horizontal Closed-Loop & 9.4 & 744 & 12.9 & 744 \\
\hline & Vertical Closed-Loop & 9.1 & 778 & 11.6 & 778 \\
\hline \multirow{3}{*}{ Camp Zama } & Open-Loop & $5.4-16.6$ & 15,227 & $6.1-25.8$ & 14,724 \\
\hline & Horizontal Closed-Loop & $13.4-16.7$ & 9,145 & $15.5-15.8$ & 8,242 \\
\hline & Vertical Closed-Loop & $13.6-15.3$ & 8,995 & $15.6-17.2$ & 8,333 \\
\hline \multirow{3}{*}{ Sagami Depot } & Open-Loop & $4.6-6.8$ & 2,077 & $5.2-7.7$ & 2,077 \\
\hline & Horizontal Closed-Loop & $5.6-11.3$ & 1,313 & 11.0 & 761 \\
\hline & Vertical Closed-Loop & $4.8-7.5$ & 1,384 & $5.1-8.2$ & 1,384 \\
\hline \multirow{3}{*}{ SFHA } & Open-Loop & $5.5-21.2$ & 137 & - & - \\
\hline & Horizontal Closed-Loop & 8.4 & 0 & - & - \\
\hline & Vertical Closed-Loop & 9.7 & 1 & - & - \\
\hline \multirow{3}{*}{ Yokohama ND } & Open-Loop & 7.0 & 174 & 8.0 & 174 \\
\hline & Horizontal Closed-Loop & $6.4-13.7$ & 202 & 7.0 & 45 \\
\hline & Vertical Closed-Loop & $8.4-9.2$ & 215 & $9.1-10.5$ & 215 \\
\hline
\end{tabular}

These findings are driven predominantly by the high cost of fossil fuels. The Kanto installations do not have an ideal climate for GSHPs because of the dominant heating season, but the imbalance between heating and cooling loads could be mitigated by selecting large buildings with high internal heat gains. 
In addition to energy and cost savings, GSHP systems generally reduce greenhouse gas emissions. If all economic open-loop GSHPs are installed, a total of 2,381 tons of $\mathrm{CO}_{2}$ per year would be saved. For all horizontal closed-loop GSHPs, 1,242 tons of $\mathrm{CO}_{2}$ could be saved. For vertical closed-loop GSHPs, 1,243 tons of $\mathrm{CO}_{2}$ could be saved. The $\mathrm{CO}_{2}$ reduction for each project is based on the fossil fuel reduction, the change in electricity consumption, and the associated emissions factors.

GSHPs have a distinct advantage over other renewable energy sources for implementation at the Kanto installations. Because GSHPs are a retrofit technology, they would be funded through the Installation Management Command (IMCOM), rather than through Japanese funding sources. This improves the chances of receiving funding, especially through appropriated sources like ECIP.

The next step would be to choose individual buildings appropriate for retrofit based on the results listed in Appendix E-1 and on land availability for heat exchange wells and/or piping. It is unlikely that GSHP projects at the Akasaka PC, Sagami General Depot, SFHA, and Yokohama ND will be implemented because of space limitations and/or mission conflicts. Camp Zama, on the other hand, is likely to find a number of promising options for GSHPs.

Once specific buildings have been identified, a project can be assembled and submitted for ECIP funding. When funding is obtained, experienced designers can be involved to gather further sitespecific data and specify a project. Detailed results are provided in Appendix E.

\section{Solar Energy Findings and Recommendations}

With current electricity prices and the available solar resource, solar electricity did not prove economic for the Kanto installations. The area's solar resource was found to be 3.0 to 3.9 $\mathrm{kWh}_{\text {solar }} / \mathrm{m}^{2} /$ day, depending on the technology and exact location. Ground-mounted fixed-angle photovoltaics (PV), axis-tracking PV, and building-integrated roof-mounted PV were all too expensive for the amount of energy that could be produced.

Table 6 shows the resource availability and economic results for the ECIP funding and thirdparty financing analyses for the PV technologies. The marginal electric rate used for the PV economic analysis at the Kanto installations, $¥ 12.0 / \mathrm{kWh}$, excludes charges that occur at night, as PV arrays do not operate during these times. Because Camp Zama is the largest of the Kanto installations in both size and energy consumption, Camp Zama rates were used to analyze project economics for all five installations, but the rates at the other installations are similar. 
Table 6: Solar Resource and Economic Results at the Kanto Installations

\begin{tabular}{|l|c|c|c||}
\hline Solar PV Technology & $\begin{array}{c}\text { Ground-Mounted } \\
\text { Fixed-Tilt PV }\end{array}$ & $\begin{array}{c}\text { Ground- } \\
\text { Mounted Axis- } \\
\text { Tracking PV }\end{array}$ & $\begin{array}{c}\text { Roof-Mounted Si } \\
\text { PV }\end{array}$ \\
\hline $\begin{array}{l}\text { Solar Insolation } \\
\left.\text { (kWh }_{\text {solar }} \mathbf{m}^{2} / \mathbf{y r}\right)\end{array}$ & 1,118 & 1,330 & 1,090 \\
\hline $\begin{array}{l}\text { Electric Production } \\
\text { (kWh }_{\text {electric } \mathbf{y r )}}\end{array}$ & $1,029,353$ & $1,162,342$ & 957,524 \\
\hline $\begin{array}{l}\mathbf{C O}_{\mathbf{2}} \text { Emissions } \\
\text { Savings (kg/yr) }\end{array}$ & 457,033 & 516,080 & 425,141 \\
\hline $\begin{array}{l}\text { Equipment Cost } \\
\text { Assumptions (¥/kW) }\end{array}$ & $¥ 585,000$ & $¥ 845,000$ & $¥ 487,500$ \\
\hline SIR & 0.18 & 0.12 & 0.19 \\
\hline Simple Payback (yrs) & 78 & 115 & 72 \\
\hline $\begin{array}{l}\text { Cost of Electricity at } \\
\text { 10\% IRR (¥/kWh) }\end{array}$ & 109.6 & 140.9 & 99.4 \\
\hline
\end{tabular}

Despite the apparently poor economics, PV technologies should not be dismissed because they are one of the most practical renewable technologies for the Japan installations with regard to siting and potential for GOJ financing. Discussions with GOJ or TEPCO should include the possibility of a PV project, especially in light of the upcoming renegotiations regarding the Utility Cost Sharing program. Furthermore, advances in PV technology are expected to produce less expensive solar cells, and GOJ is working to increase solar PV installations in Japan. See Appendix A for analysis details.

\section{Geothermal Power Plant Findings and Recommendations}

The Kanto installations are estimated to have temperatures of 50 to $75^{\circ} \mathrm{C}$ at economic drilling depths, which is not sufficient for economic development of geothermal power generation. Furthermore, there is much local opposition to development of high-temperature resources for energy generation because of the tourism industry and local interest in hot springs. The economic results are shown in Table 7. It is not recommended for any of the Kanto installations to pursue a geothermal energy project.

Table 7: Economic Assessment of Geothermal Power

\begin{tabular}{|c|c|c|c||}
\hline $\begin{array}{c}\text { Financing } \\
\text { Scenario }\end{array}$ & \multicolumn{2}{|c|}{ ECIP } & IPP \\
\hline $\begin{array}{c}\text { Economic } \\
\text { Factor }\end{array}$ & SIR & $\begin{array}{c}\text { Simple } \\
\text { Payback } \\
\text { (years) }\end{array}$ & $\begin{array}{c}\text { Cost of Electricity } \\
\text { at 10\% IRR } \\
\text { (¥/kWh) }\end{array}$ \\
\hline Results & 0.51 & 25.4 & 38.34 \\
\hline
\end{tabular}

\section{Wind Energy Findings and Recommendations}

The wind resource at the Kanto installations is not sufficient to provide for an economically viable wind project. The average wind speed is $5.97 \mathrm{~m} / \mathrm{s}$, which is Class 2 wind. A wind turbine 
also requires sufficient land area in a location where the height of the structure will not interfere with radar or other mission or local activities. The Kanto installations' small sizes in populated areas are not suitable for a wind turbine. This siting challenge, combined with the economics shown in Table 8, result in poor potential for a wind generation project. It is not recommended to pursue a wind project at any of the Kanto installations. This analysis is detailed in Appendix B.

Table 8: Economic Assessment of Wind Power

\begin{tabular}{|c|c|c|c||}
\hline $\begin{array}{c}\text { Financing } \\
\text { Scenario }\end{array}$ & \multicolumn{2}{|c|}{ ECIP } & IPP \\
\hline $\begin{array}{c}\text { Economic } \\
\text { Factor }\end{array}$ & SIR & $\begin{array}{c}\text { Simple } \\
\text { Payback } \\
\text { (years) }\end{array}$ & $\begin{array}{c}\text { Cost of Electricity } \\
\text { at 10\% IRR } \\
\text { (¥/kWh) }\end{array}$ \\
\hline Results & 0.32 & 41.2 & 40.26 \\
\hline
\end{tabular}

\section{Biomass Findings and Recommendations}

For the Kanto installations, procuring feedstock from offsite sources is not an option because of environmental restrictions. Thus, only onsite resources are feasible for use in a biomass plant. Because of the limited land area at each of the Kanto installations, there is insufficient biomass available for an economic energy generation project. Resources evaluated include crop residue, animal waste, dedicated energy crops, logging residue, industrial waste, landfill gas, and wastewater treatment plant (WWTP) sludge. See Appendix C for more details. 


\section{Project Implementation in Japan}

The topic of renewable energy project implementation for U.S. Army installations in Japan has never been approached by installation personnel or Japanese authorities. The ability to develop such a project will require extensive research into the existing contractual obligations of each party, new contracts that could be developed, the legality of certain partnerships, and available financing avenues.

\section{Policies, Standards, and Regulatory Structure}

Both Japanese and U.S. structures and policies with regard to project implementation and approval are complicated and require multiple levels of involvement. On the Japanese side, the key players are GOJ, the local governments, and the utilities. GOJ is the authority when directly dealing with U.S. projects, but local governments can overrule many GOJ decisions. When electricity is involved, as with renewable energy project development, the monopolistic utilities (TEPCO in the case of the Kanto installations) also need to be involved and approve any changes to their provider contracts. They own the transmission and distribution lines, and are not likely to participate in a project that does not provide them some benefit.

On the U.S. side, the key players are JED, USFJ, the Air Force, the Army, and the installation, all of whom must approve a project like this before it can be executed. USFJ is the representing body for all four services in Japan. JED, part of the Corps of Engineers, makes final decisions for the USFJ, tracks unity among the services, executes new construction contracts with GOJ, and engineers and designs construction projects. Because the Army makes up less than 5\% of USFJ, they have limited internal support and need to rely on other services for certain capabilities. For instance, the Air Force executes non-Military Construction (MILCON) construction contracts for the Army. Also because of the Army's small contribution to USFJ, they often get outvoted during JED meetings. The installation is only involved at the installation level.

The IPP model used for renewable energy project development in the United States, which assumes a third party would fund, own, and operate the generation facility and sell power to DoD through a PPA, would be difficult to implement under this complicated structure. First of all, an IPP may not even exist in Japan, because the IPP power prices would have to compete with those of the large utilities controlling the grid, and the utilities would need to allow them use of the transmission lines. The large utilities like TEPCO could, theoretically, build a renewable energy project for the U.S. installations, but that small scale would not be worthwhile for a utility providing energy to a large portion of the nation, as well as trying to meet Japan's renewable energy portfolio standard (although modest).

Additionally, GOJ and USFJ have an FIP agreement that requires Japan to fund all new construction. The FIP stipulates that the total U.S. facility square footage must remain the same, so if a new facility is built, it must be replacing a demolished facility with the same square footage. This includes utility line work, and so probably includes onsite power generation facilities as well, although this has not been verified. MILCON funding could help fund a renewable energy project, but because of the FIP, USFJ receives little MILCON funding. 
It is likely that GOJ would have to fund the project and provide contractors to build it, DoD would own the equipment, and O\&M would be contracted out to GOJ. While this seems like a reasonable option, it is questionable whether GOJ would be willing to fund such a project at this time. The benefit of the project must be proven to them.

\section{Potential Solutions}

The Japanese renewable portfolio standard may not be ambitious, but renewable energy projects also reduce greenhouse gas emissions. The current Japanese government is placing a higher priority than those in the past on reducing greenhouse gas emissions and meeting the Kyoto Protocol. Therefore, projects presented with an emphasis on $\mathrm{CO}_{2}$ reduction rather than use of renewable resources may be more attractive to GOJ.

Another potential approach would be to include renewable energy projects in the upcoming discussions with GOJ regarding renegotiation of the UCS program. GOJ wants to subsidize less of USFJ's utility bills, and a compromise could include the exchange of a renewable energy project for smaller subsidies. A PV array, which is not economic but installations are being encouraged by GOJ, may be a good choice for this type of exchange.

Because USFJ also needs to approve and help implement renewable energy projects, partnering with other services in Japan could be beneficial. Additional opportunities may present themselves with involvement of more prominent services, including the Air Force and the Marines. Larger, more economic WTE or biomass projects could become feasible. Economies of scale could come into play with a large purchase of multiple PV arrays, even if they are installed at different locations. Additional land may be available for locating GSHPs or wind turbines.

It is recommended to share the results of this report with other services and begin discussions about how to implement renewable energy for USFJ, not only the U.S. Army in Japan. 


\section{APPENDIX A}

Analys is of Solar Opportunities 



\section{Appendix A: Analys is of Solar Opportunities}

\section{Solar Technology}

Japan is a world leader in photovoltaics (PV) research, module fabrication, and array installation. Several established PV manufactures such as Sharp, Kyocera, Sanyo Electric are headquartered in Japan, and as of 2006, Japan has installed 1,422 MW of PV capacity, which is $0.6 \%$ of Japan's gross electricity generation capacity. Unlike the United States, a relatively large fraction of Japan's PV capacity has been installed on homes and not at large, multi-megawatt PV power plants. Also, Japan's PV market is overwhelmingly dominated by silicon PV modules due to concerns over toxic heavy metals frequently found in other PV technologies (e.g., cadmium telluride [CdTe] thin film modules).

Japan frequently experiences high winds and earthquakes. PV arrays are typically modular, lightweight, and relatively resilient to the stresses included by earthquakes. To best withstand high winds, roof-mounted PV systems are often installed at angles that reduce the stresses that can be generated by high winds. However, these angles typically result in suboptimal panel orientation, which then results in suboptimal energy production. But, fears over typhoons have also encouraged the installation of metal roofs, which is an ideal roof type for PV module mounting.

Like most nations that find themselves overly reliant on foreign sources of energy, Japan has explored a wide range of solar technologies and applications for energy generation. Solar technologies can be classified by the specific technique used for converting solar energy into useful energy. Some solar systems capture the photonic energy of sunlight to generate electricity while other systems harvest infrared energy for direct heating applications (e.g. water heating) or for power generation. As can be seen, solar energy is flexible in that the sun's energy, or insolation, can be captured to generate electricity, heat, or a combination of both.

Solar technologies can be further categorized by their scale. Large-scale solar projects can easily exceed $1 \mathrm{MW}$ and can have hundreds of collectors. Smaller-scale projects, often at the building level, are also possible and may be more desirable because of land area limitations, aesthetics considerations, or for energy security. PV can be either large-scale or small-scale, while technologies like solar hot water heating are only found at the building level.

\section{Solar Electric Technologies}

The most common solar electric systems are simple PV arrays that harvest sunlight and convert it into electricity. Concentrating solar systems, which are less common, use concentrators in the form of mirrors and/or lenses to focus sunlight onto either a small, sophisticated PV solar cell or a receiver that harvests the light's thermal energy for the purposes of power generation. This analysis focuses on PV arrays because the Kanto installations do not have a sufficient solar resource for concentrating technologies. There are two major PV array subcategories:

- Flat Pane Systems. PV modules can be mounted on racks either at ground level or on rooftops at a fixed angle. Generally, this angle is equal to the location's latitude. On rooftops, the angle can be the angle of the rooftop or an angle set by mounting brackets 
attached to the roof. In addition, there are two common PV technologies on the market, silicon PV and cadmium telluride thin film PV. Other PV technologies such as gallium arsenide (GaAs) and copper-indium selenide (CIGS) are available, but uncommon.

- Axis-Tracking Systems. PV arrays can be mounted on an assembly that moves throughout the day that keeps the array positioned at an optimum angle to maximize the captured sunlight (Figure A.1). An axis-tracking system can be either single- or dual-axis in nature. A single-axis tracking system typically has a fixed tilt and the system follows the sun's trajectory across the sky. These systems are able to collect more sunlight than non-tracking systems. A dual-axis tracking system allows the panels to rotate along two axes, thereby truly maximizing the panel's ability to harvest solar energy. However, these systems are considerably more complex and impose additional operations and maintenance costs than flat panel assemblies.

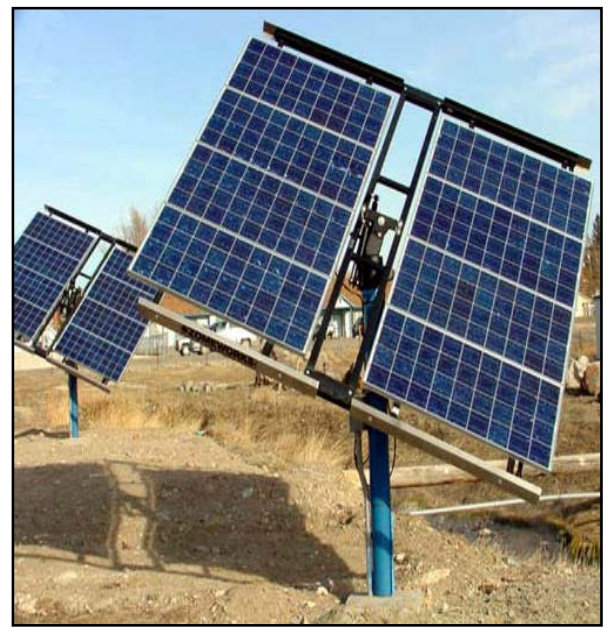

Figure A.1: Axis-Tracking PV Array

\section{Solar Thermal}

Rather than electricity as the end product, solar energy can also be used to directly heat air in the form of transpired solar collectors (i.e., solar walls), water that is used for space heating, or water that is used for service hot water (SHW) or swimming pools. These solar energy systems can be economic even when PV is not. Solar thermal projects do not count towards the EPAct mandate, but were considered for requested locations at the Japan sites because of the small-scale nature of the installations.

\section{Solar Analysis Approach}

The analytic approach for the solar energy assessment consists of the following steps.

- Identify solar potential-Use established sources to determine seasonal and annual solar radiation for the site.

- Determine utility perspective-Obtain electric rate tariff information, evaluate applicable regulations, and identify grants, incentives, and other support. 
- Determine applicable solar technology_ Evaluate solar electric technologies including both large-scale (approximately 1+ MW) applications, such as a ground-mounted PV array, and small-scale (kW-scale) applications, such as roof-mounted PV systems.

- Develop project economics-Determine project capital investment requirements, project operations and maintenance costs, and calculate the economic value of expected electric production based on selected solar technology and market prices.

\section{Solar Resource Characterization}

The island of Honshu experiences insolation levels ranging between $3.0 \mathrm{kWh} / \mathrm{m}^{2} /$ day to 3.9 $\mathrm{kWh} / \mathrm{m}^{2} /$ day. From a resource perspective, the Kanto installations are positioned in a region with a moderately low solar potential. Figure A.2 displays the annual mean horizontal insolation on a flat collector.

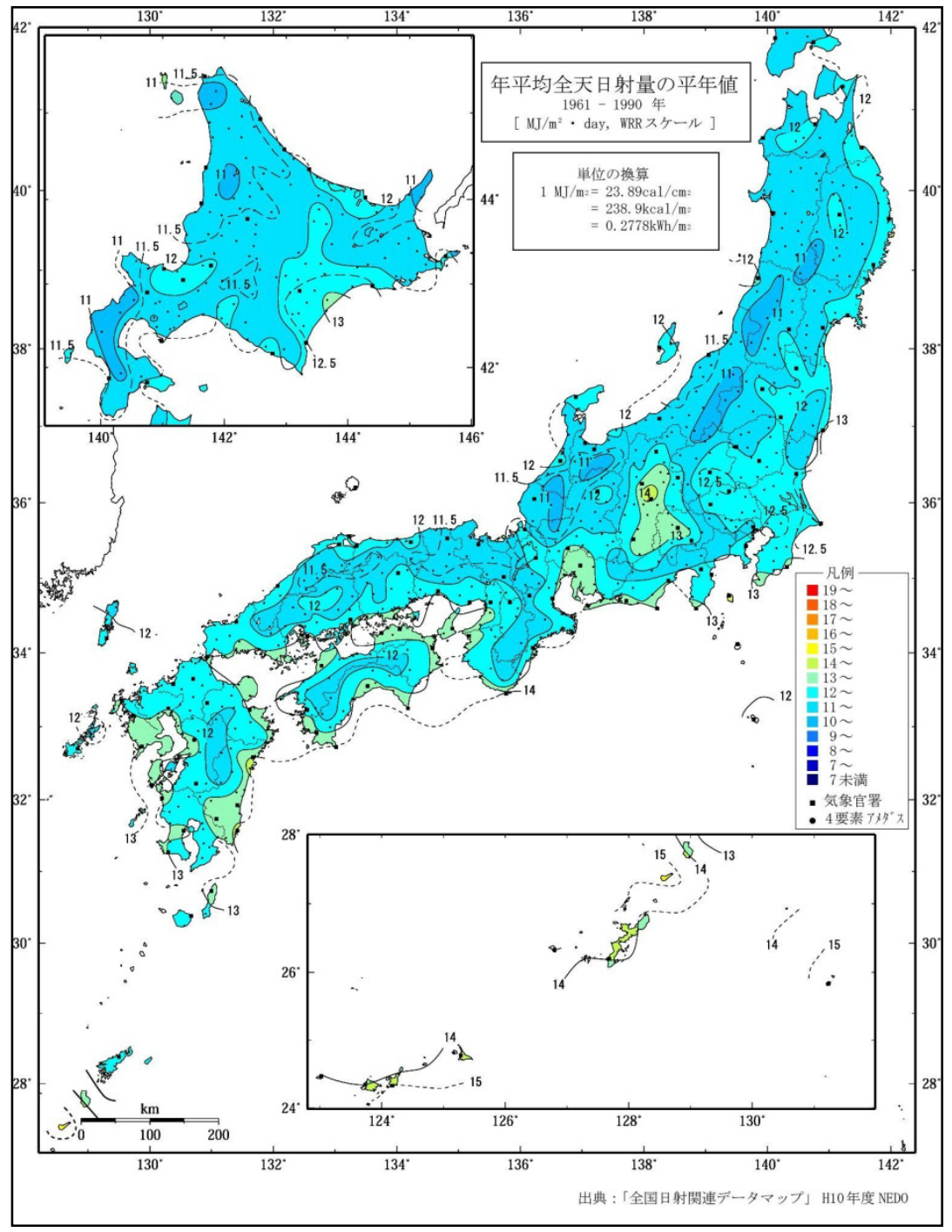

Figure A.2: Solar Insolation Levels (Tsuna-san 2008) 
The solar resource potential was estimated using the solar potential estimates in National Aeronautic and Space Administration's (NASA's) Surface Meteorology and Solar Energy (SSE) data and Natural Resources Canada's RETScreen analysis software. The SSE data set is a continuous and consistent 10 -year global climatology of insolation and meteorology data on a $1^{\circ}$ by $1^{\circ}$ grid system. Although the SSE data within a particular grid cell are not necessarily representative of a particular microclimate within the cell, the data are considered to be the average over the entire area of the cell. That estimate should be sufficiently accurate for preliminary feasibility studies of new renewable energy projects.

Table A.1 shows the average solar insolation data for several different surface orientations. Average monthly insolation values are provided in $\mathrm{kWh} / \mathrm{m}^{2} /$ day for the following conditions:

- Tilt 0 - Collector installed at a $0^{\circ}$ tilt (e.g., on a flat surface such as a roof).

- Tilt (lat-15) - A tilt of latitude minus $15^{\circ}$ would favor energy production in the summer when the sun is higher in the sky.

- Tilt lat - Tilting a PV array at an angle equal to the latitude is a generally accepted way to optimize annual electricity production.

- Tilt (lat+15) - A tilt of latitude plus $15^{\circ}$ would favor energy production in the winter when the sun is lower in the sky.

- Tilt 90 - Collector installed against a vertical surface (i.e., a wall).

- Single-Axis Tracking - A collector capable of tracking the sun's azimuth angle over the course of the day.

Table A.1: Monthly Averaged Insolation at the Kanto Installations (kWh/m $\left./ \mathrm{m}^{2} / \mathrm{day}\right)$ (NRC 2010, NASA 2010)

\begin{tabular}{|c|c|c|c|c|c|c|c|c|c|c|c|c|c||}
\hline & Jan & Feb & Mar & Apr & May & Jun & Jul & Aug & Sep & Oct & Nov & Dec & $\begin{array}{c}\text { Annual } \\
\text { Average }\end{array}$ \\
\hline Tilt 0 & 2.16 & 2.63 & 3.12 & 3.56 & 3.91 & 3.46 & 3.83 & 3.85 & 2.9 & 2.30 & 2.11 & 1.93 & 2.98 \\
\hline Tilt 20 & 2.79 & 3.11 & 3.38 & 3.64 & 3.86 & 3.37 & 3.75 & 3.88 & 3.04 & 2.55 & 2.62 & 2.55 & 3.21 \\
\hline Tilt 35 & 3.12 & 3.30 & 3.41 & 3.52 & 3.63 & 3.15 & 3.50 & 3.70 & 2.99 & 2.61 & 2.86 & 2.87 & 3.22 \\
\hline Tilt 50 & 3.26 & 3.32 & 3.28 & 3.26 & 3.28 & 2.83 & 3.15 & 3.39 & 2.83 & 2.55 & 2.94 & 3.03 & 3.09 \\
\hline Tilt 90 & 2.83 & 2.61 & 2.29 & 2.03 & 1.89 & 1.65 & 1.80 & 2.02 & 1.89 & 1.90 & 2.46 & 2.68 & 2.17 \\
\hline $\begin{array}{c}\text { Single- } \\
\text { Axis } \\
\text { Tracking }\end{array}$ & 3.64 & 3.79 & 3.91 & 3.95 & 4.07 & 3.50 & 3.88 & 4.24 & 3.29 & 2.88 & 3.28 & 3.34 & 3.65 \\
\hline
\end{tabular}

As shown, a flat collector tilted at $35^{\circ}$ (the site's latitude) has an average yearly solar potential of $3.2 \mathrm{kWh}_{\text {solar }} / \mathrm{m}^{2} /$ day. A single-axis tracking PV array will receive $3.7 \mathrm{kWh}_{\text {solar }} / \mathrm{m}^{2} /$ day of incident solar radiation. Figure A.3 shows this incident solar radiation on a flat roof surface ( $0^{\circ}$ tilt), a fixed array (latitude tilt), and a single-axis tracking array at the Kanto installations. 


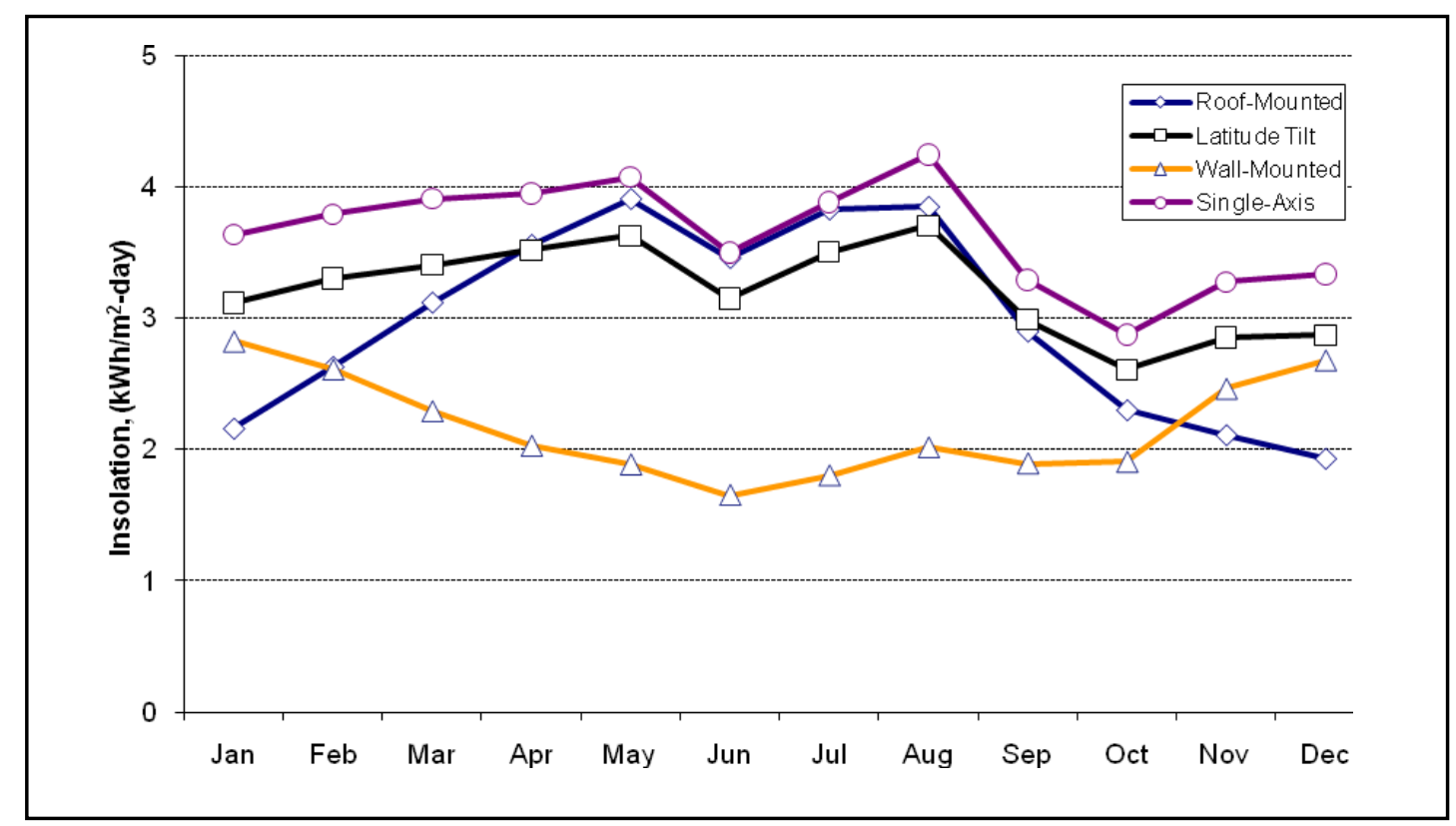

Figure A.3: Average Daily Insolation at the Kanto Installations (NASA 2010)

\section{Siting Considerations for PV Technologies}

Compared to most renewable energy technologies, PV panels have a fair degree of siting flexibility. As previously mentioned, an array can be mounted on the ground or upon existing buildings and structures. Potential site needs to be free of any objects, such as trees or buildings, which may cast a shadow on the array. Also, the system will require an inverter to convert the DC output power into AC power. For projects $25 \mathrm{~kW}$ or larger, it is common to use multiple inverters to optimize the system's efficiency as well as provide redundancy.

A typical 1-kW PV array may range in size from 5 to $10 \mathrm{~m}^{2}$ depending on the cell efficiency; however, a larger array requires access space as well as spacing between the rows of panels to avoid self-shading, and will subsequently require a greater amount of space per installed $\mathrm{kW}$. For example, a $30-\mathrm{kW}$ array would require $500 \mathrm{~m}^{2}$, and a $100-\mathrm{kW}$ array may require nearly $2,000 \mathrm{~m}^{2}$, assuming that the PV array occupies $50 \%$ of the space. Panels mounted on slanted roofs can usually be more tightly grouped because of a decrease in self-shading potential. In addition, large arrays can produce considerable amounts of energy and require siting near existing high voltage power lines.

The Kanto installations do not have sufficient open space for a large ground-mounted PV array. Consequently, most PV deployment will have to focus on building-integrated PV.

\section{Findings: Solar Electric Production}

Solar conversion is an inefficient process; typical PV cells have a conversion efficiency ranging from $10 \%$ to $20 \%$. Taking into account the annual solar potential and the efficiency of a typical PV system, each fixed-angle, latitude-tilted MW of installed PV would be expected to produce $1,029,000 \mathrm{kWh}_{\text {electric }}$ at the Kanto installations. The system would have a capacity factor of $11.8 \%$, which is low even for solar arrays. 
A single-axis tracking PV array can produce significantly more electricity than a stationary PV array, resulting in a higher output per unit surface area, and has a much flatter energy output profile during the day. The tracking racks increase the cost of installation by approximately $¥ 100$ to $¥ 200$ per installed watt. A 1-MW single-axis tracking array would produce $1,162,000$ $\mathrm{kWh}_{\text {electric }}$ annually at the Kanto installations. The system would have a capacity factor of $13.3 \%$.

A building-mounted PV array installed on a flat roof at the Kanto installations would be expected to produce 958,000 $\mathrm{kWh}_{\text {electric }}$ annually per $1 \mathrm{MW}$ of installed capacity. The system would have a capacity factor of $10.9 \%$.

A summary of the solar electric production information can be found in Table A.2. Emissions savings are based on the replacement of electricity generated in Japan, which generates an average of $0.444 \mathrm{~kg}$ of $\mathrm{CO}_{2}$ per $\mathrm{kWh}$ produced (FEPC 2009).

Table A.2: Solar Electric Production by System Type at the Kanto Installations

\begin{tabular}{|c|c|c|c|c|c|c|}
\hline System Type & $\begin{array}{c}\text { Assumed } \\
\text { PV } \\
\text { Module } \\
\text { Efficiency }\end{array}$ & $\begin{array}{c}\text { Solar } \\
\text { Insolation, } \\
\mathbf{k W h}_{\text {(solar) }} / \mathbf{m}^{2} / \mathbf{y r}\end{array}$ & $\begin{array}{c}\text { Electric } \\
\text { Production, } \\
\mathbf{k W h}_{\text {(electric) }} / \mathbf{y r}\end{array}$ & $\begin{array}{c}\text { Specific } \\
\text { Yield, } \\
\left(\mathbf{k W h} / \mathbf{m}^{2}\right)\end{array}$ & $\begin{array}{c}\mathrm{CO}_{2} \\
\text { Emissions } \\
\text { Savings } \\
\text { (kg/yr) }\end{array}$ & $\begin{array}{l}\text { Capacity } \\
\text { Factor }\end{array}$ \\
\hline $\begin{array}{l}1 \text { MW South- } \\
\text { Facing, } \\
\text { Latitude Tilt }\end{array}$ & $19.0 \%$ & 1,118 & $1,029,353$ & 196 & 457,033 & $11.8 \%$ \\
\hline $\begin{array}{l}1 \text { MW Single- } \\
\text { Axis Tracking }\end{array}$ & $19.0 \%$ & 1,330 & $1,162,342$ & 221 & 516,080 & $13.3 \%$ \\
\hline $\begin{array}{l}1 \text { MW Roof- } \\
\text { Mounted } \\
\text { Silicon PV }\end{array}$ & $19.0 \%$ & 1,090 & 957,524 & 182 & 425,141 & $10.9 \%$ \\
\hline
\end{tabular}

\section{Findings: Solar Project Economics}

Based on current average solar system costs in the United States, an assumption that prices are $30 \%$ higher in Japan, and the projected performance for the various solar system configurations, life-cycle costs were developed for solar technologies at the Kanto installations under two funding scenarios:

- Appropriated, using Energy Conservation Investment Program (ECIP) funds, and

- Third party financing via an independent power producer (IPP).

Although it is unlikely that a third party will contractually be able to develop a renewable project for the U.S. Army in Japan, this scenario was analyzed to show an alternative to appropriated funding, which will be difficult to obtain for high-cost projects. Also, the IPP scenario may be representative of a project developed, owned, and operated by the Government of Japan (GOJ).

Cost-effective ECIP projects have savings-to-investment ratio (SIR) values greater than 1.0, while a $10 \%$ internal rate of return (IRR) shows whether the IPP scenario is cost-effective. Third-party financing utilizes a third party to develop, fund, and own the projects under a power 
purchase agreement (PPA) or other vehicle. Building-integrated PV can also be developed by a third party.

Solar PV arrays are generally no larger than several megawatts and are not capable of providing baseload power due to their intermittent nature. Therefore, PV arrays can typically only displace electricity charges and not demand charges. This electricity-only charge is known as the marginal electric rate. The rate for the Kanto installations is structured such that daytime and nighttime hours are charged different rates. Consequently, the marginal electric rate used for PV excludes charges that occur at night, as PV arrays do not operate during these times. All five Kanto installations have slightly different rates, but they are mostly similar. Because Camp Zama is the largest of the Kanto installations in both size and energy consumption, Camp Zama rates were used to analyze project economics for all five installations. The daytime marginal electric rate for the Kanto installations was calculated to be $¥ 12.0 / \mathrm{kWh}$.

At this time, none of the systems considered are cost-competitive with this rate. The combination of the moderate solar resource, high system capital costs, and a lack of incentives for large-scale PV projects in Japan is the principle barrier to economic solar power generation at the Kanto installations. The SIR and simple payback for the ECIP scenario, the cost of electricity at a 10\% IRR for the IPP scenario, and the assumed system costs are shown in Table A.3 for each technology. This analysis assumed a 3.0\% discount rate, a $1.2 \%$ general inflation rate, and a 1.2\% annual electric cost inflation rate. The 3.0\% discount rate is a typical value used for net present value (NPV) calculation while the $1.2 \%$ general inflation rate is based upon national statistics. The analysis also included a 38.1\% national income tax, a $9.6 \%$ prefecture income tax, a 5.0\% sales tax, and a 1.7\% property tax.

There is only one incentive available in Japan that could bring the cost of solar energy down, but it would not impact an array developed on U.S. Army land. For businesses and non-residential buildings, excess electricity generation can be sold back to the utility at a rate of $¥ 24 / \mathrm{kWh}$, up to $500 \mathrm{~kW}$. For residential buildings, excess electricity can be sold for $¥ 48 / \mathrm{kWh}$, up to $10 \mathrm{~kW}$ (Energy Conservation and Renewable Energy Department 2009). Because an array would be developed behind the single meter serving the entire installation, little to no excess electricity would be generated for sale back to the utility.

Table A.3: Economic Results for Solar Technologies at the Kanto Installations

\begin{tabular}{|l|c|c|c||}
\hline $\begin{array}{l}\text { Solar PV } \\
\text { Technology }\end{array}$ & $\begin{array}{c}\text { Ground-Mounted } \\
\text { Fixed-Tilt PV }\end{array}$ & $\begin{array}{c}\text { Ground-Mounted } \\
\text { Axis-Tracking PV }\end{array}$ & $\begin{array}{c}\text { Roof-Mounted } \\
\text { Si PV }\end{array}$ \\
\hline $\begin{array}{l}\text { Equipment Cost } \\
\text { Assumptions (¥/kW) }\end{array}$ & $¥ 585,000$ & $¥ 845,000$ & $¥ 487,500$ \\
\hline SIR & 0.18 & 0.12 & 0.19 \\
\hline Simple Payback (yrs) & 78 & 115 & 72 \\
\hline $\begin{array}{l}\text { Cost of Electricity at } \\
\mathbf{1 0 \%} \text { IRR (¥/kWh) }\end{array}$ & 109.6 & 140.9 & 99.4 \\
\hline $\begin{array}{l}\text { Variable O\&M } \\
\text { (¥/kWh) }\end{array}$ & $¥ 0.0$ & $¥ 0.0$ & $¥ 0.0$ \\
\hline $\begin{array}{l}\text { Fixed O\&M } \\
\text { (¥/net kW) }\end{array}$ & $¥ 2,600$ & $¥ 4,300$ & $¥ 2,600$ \\
\hline
\end{tabular}




\section{Solar: Next Steps}

Solar energy projects are not cost-effective at this time because of the Kanto installations' moderate solar energy resource and current PV capital costs. Therefore, no action needs to be taken at this time, but the Kanto installations should continue to monitor the market conditions affecting solar energy. Advances in PV technology are expected to produce less expensive solar cells, although rising demand for PV may negate some of the potential price drop. Rising energy rates may do the most to tip the scales in favor of solar electric. Discussions with GOJ or the Tokyo Electric Power Company could include the possibility of a PV project, especially in light of the upcoming renegotiations regarding the Utility Cost Sharing program.

\section{Solar Sources of Information}

Energy Conservation and Renewable Energy Department. 2009. New Buyback Program for Photovoltaic Generation. Agency for Natural Resources and Energy, Ministry of Economy, Trade, and Industry. Presentation provided by Camp Zama personnel. November 2009.

FEPC-The Federation of Electric Power Companies of Japan. 2009. Environmental Action Plan by the Japanese Electric Utility Industry. September 2009. Accessed May 2010 at http://www.fepc.or.jp/english/library/environmental_action_plan/index.html.

Tsuna-san. 2008. “Annual Insolation in Japan.” BIGLOBE Webry Blog. Accessed June 2010 at http://sunatsubu.at.webry.info/200809/article_3.html (last updated September 14, 2008).

LBNL_Lawrence Berkeley National Laboratory. 2009. “Tracing the Sun: The Installed Cost of Photovoltaics in the U.S. from 1998-2007.” February 2009.

NRC-Minister of Natural Resources Canada. 2010. RETscreen Clean Energy Project Analysis Software. RETScreen International Clean Energy Decision Support Centre, Minister of Natural Resources Canada, Ottawa, Ontario, Canada. Accessed May 2010 at http://www.retscreen.net (last updated March 3, 2010).

National Aeronautics and Space Administration. Surface Meteorology and Solar Energy Database. 2010. Accessed May 2010 at http://eosweb.larc.nasa.gov/cgi-bin/sse. 


\section{APPENDIX B}

\section{Analys is of Wind Opportunities}





\section{Appendix B: Analysis of Wind Opportunities}

\section{Wind Technology}

According to the Global Wind Energy Council (GWEC), Japan has the wind resource to support an installed capacity of 1.5 gigawatts (GWEC 2009). There are around 1,400 wind turbines currently installed in Japan (Nakata 2008). Japan's total installed capacity has grown from 136 MW in 2000 to 1,880 MW in 2008.

Wind turbines come in many different sizes and configurations. The industry standard wind turbine employs the Danish configuration - a horizontal-axis, three-bladed rotor, an upwind orientation, and an active yaw system to keep the rotor oriented into the wind.

Turbines for bulk power production tend to be $660 \mathrm{~kW}$ to $3 \mathrm{MW}$ in size. Hub heights can range from 50 meters (164 feet) to 80 meters (262 feet) and higher. Turbines for consumer and remote grid production are found in the range of $50 \mathrm{~kW}$ to $250 \mathrm{~kW}$. Hub heights range between 25 meters ( 80 feet) and 40 meters (131 feet). Residential-scale wind turbines are used for remote power, battery charging, or net-metering generation. These turbines tend to be 400 watts to 50 $\mathrm{kW}$. For turbines greater than $1 \mathrm{~kW}$, the hub heights range from 12 meters (40 feet) to 36 meters (120 feet).

Japan, as an island nation, experiences typhoons, strong wind gusts, and high wind turbulence. A number of wind turbines have been severely damaged from extreme weather conditions. In 2003, a strong typhoon broke five wind turbines on Okinawa's Miyako Island. Wind speeds reached more than $252 \mathrm{kph}$ (Nakata 2008). To address this problem, various Japanese agencies are working together to develop design and safety standards for turbines operating in Japan that go beyond what is required by the International Electrotechnical Commission (IEC) (GWEC 2009).

\section{Wind Analysis Approach}

For this analysis, Pacific Northwest National Laboratory (PNNL) used the following approach to analyze the economic potential for wind energy at the Kanto installations in the Tokyo area.

- Analyze wind resource maps and publicly available wind data to develop a wind resource characterization.

- Evaluate existing onsite interconnection and transmission capacity and availability, to the extent possible.

- Survey local wind developer activity in the area to assess potential interest in developing projects.

- Select a turbine model to establish cost and performance parameters of a potential wind energy project.

- Estimate total project cost, including project development, generation equipment, balance of plant construction, operation and maintenance (O\&M), taxes, and tax credits and other policy incentives. 
- $\quad$ Determine economic feasibility utilizing different financing scenarios: IPP and ECIP.

- Determine project feasibility and recommend next steps.

\section{Wind Resource Characterization}

To construct a wind resource characterization for the Kanto installations, PNNL used publicly available information from 3TIER's FirstLook online wind resource tool, the wind energy maps available from the New Energy and Industrial Technology Development Organization (NEDO), and NASA Surface Meteorology and Solar Energy (SSE) data.

According to industry standards developed as part of the Wind Energy Resource Atlas of the United States, there are seven main classes of wind power, as defined in Table B.1. Wind power class definitions are a convenient benchmarking tool. A strong Class 3 resource, preferably Class 4, is generally required to achieve an economic project on a large, commercial scale.

Table B.1: Classes of Wind Power Density at $50 \mathrm{~m}$

\begin{tabular}{|c|c|c|}
\hline $\begin{array}{c}\text { Wind Power } \\
\text { Class }\end{array}$ & $\begin{array}{c}\text { Wind Power } \\
\text { Density, W/m }\end{array}$ & Speed, m/s (mph) \\
\hline 1 & $<200$ & $<5.6(12.5)$ \\
\hline 2 & $200-300$ & $5.6(12.5)-6.4(14.3)$ \\
\hline 3 & $300-400$ & $6.4(14.3)-7.0(15.7)$ \\
\hline 4 & $400-500$ & $7.0(15.7)-7.5(16.8)$ \\
\hline 5 & $500-600$ & $7.5(16.8)-8.0(17.9)$ \\
\hline 6 & $600-800$ & $8.0(17.9)-8.8(19.7)$ \\
\hline 7 & $>800$ & $>8.8(19.7)$ \\
\hline
\end{tabular}

The NEDO Japan wind resource map uses a color-coding scheme (each $0.5 \mathrm{~m} / \mathrm{s}$ wind speed increment is a different color) and this scheme can easily be translated to wind power classes. Using the wind power class definitions provides a point of reference among the different data sources consulted. From these data sources, a site-specific average wind speed was selected for use in the project size calculations, which in turn are needed for the economic analysis.

The average wind speeds for Camp Zama and Yokohama North Dock (ND), according to the NEDO wind resource map, are 5.0 to $5.5 \mathrm{~m} / \mathrm{s}$ at $50 \mathrm{~m}$, as shown in Figure B.1. Both areas are marked with small, faint rectangles on the map. 


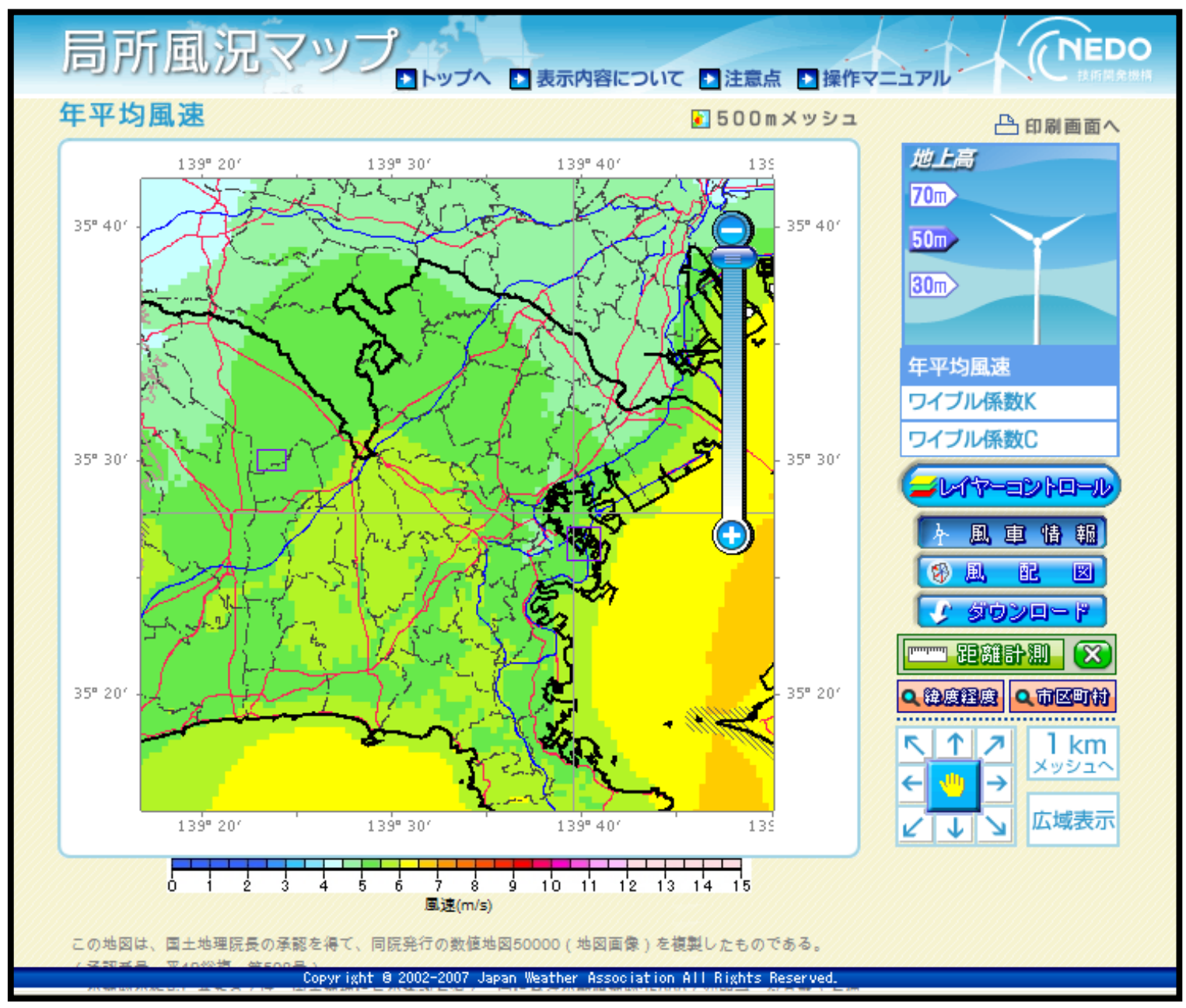

Figure B.1: Average Wind Speeds at Camp Zama and Yokohama North Dock

NASA SSE provides data on a $1^{\circ}$ by $1^{\circ}$ grid system, based on wind speed data over a 10 -year period from July 1983 to June 1993. According to this source, the annual average wind speed in the area of the Kanto installations is $5.42 \mathrm{~m} / \mathrm{s}$ at 50 meters (NASA 2009).

The wind speed data provided by the 3TIER online wind resource tool was slightly higher than the data provided from NASA or NEDO. Table B.2 summarizes wind resource for the Kanto installations according to the available data sources.

Table B.2: Summary of Wind Resource Data

\begin{tabular}{|c|l|l|l||}
\hline \hline \multirow{2}{*}{ Location } & \multicolumn{1}{|c|}{ Source } & \multicolumn{1}{c|}{ Wind Speed } & \multicolumn{1}{c|}{$\begin{array}{c}\text { Wind Power Class } \\
\text { Definition }\end{array}$} \\
\hline \multirow{3}{*}{ Camp Zama, Japan } & NEDO Wind Resource Map & $\begin{array}{l}5.25 \mathrm{~m} / \mathrm{s} \text { at } 50 \mathrm{~m} \text {, estimated } 5.97 \mathrm{~m} / \mathrm{s} \\
\text { at } 80 \mathrm{~m}\end{array}$ & Class 1 \\
\cline { 2 - 5 } & 3TIER FirstLook & $5.36-6.97(6.17 \mathrm{mean}) \mathrm{m} / \mathrm{s}$ at $50 \mathrm{~m}$ & Class 2 \\
\cline { 2 - 5 } & NASA SSE data & $5.42 \mathrm{~m} / \mathrm{s}$ at $50 \mathrm{~m}$ & Class 1 \\
\hline
\end{tabular}


Assuming a conservative, average wind speed of $5.97 \mathrm{~m} / \mathrm{s}$ at $80 \mathrm{~m}$, the net capacity factor for a wind turbine in this area would be $21.2 \%$.

\section{Siting Considerations}

After wind resource availability, the primary siting consideration for wind projects is transmission availability and the capacity of those lines. Projects need to be located within approximately 1 mile of existing transmission lines, or new lines will need to be constructed at considerable cost.

This analysis does not include any transmission costs and assumes that existing transmission lines are available to transmit power without substantial additional investment. It is also assumed that an onsite wind project would not trigger new standby or other fees from the local utility. But because wind is intermittent, the utility may have interconnection requirements to ensure grid stability and to ensure there is reliable power for the installation.

Another consideration is potential interference with airport operations and military missions. The proper notifications, permits, and approvals would need to be obtained for any type of wind project.

A wind energy project at Camp Zama or another Kanto installation faces the additional challenge of locating a turbine in a highly populated area. First of all, it is unlikely there is enough land space to site a wind turbine on installation property. Secondly, the height of the tower would very possibly cause objections from the neighbors; a water tower could not even be built on Camp Zama because it interfered with local television reception.

\section{Yokohama Wind Turbine}

In 2007, a Vestas 2.0 MW wind turbine was installed in Yokohama at Mizuho Wharf, next to Yokohama ND. The total project cost was reported to be $¥ 500$ million (City of Yokohama 2006). The turbine has an $80-\mathrm{m}$ rotor diameter and a 78-m hub height for a total tip height of $118 \mathrm{~m}$.

It was expected to generate 3 million kWh of energy annually (City of Yokohama 2006), but locals have commented that the turbine is producing less than expected; current energy production data are not available.

Yokohama ND is not associated with this turbine nor does it use energy generated from the turbine. The turbine is mentioned here as an example of the poor performance that would be expected from a wind turbine located at Yokohama ND.

\section{Wind: Economic and Other Analysis Parameters}

Because a wind energy project would provide intermittent power to the installation, the economics of a wind project are evaluated against the direct energy charge of $¥ 9.87 / \mathrm{kWh}$, which excludes demand and other fixed charges. All five Kanto installations have slightly different rates, but they are mostly similar. Because Camp Zama is the largest of the Kanto installations 
in both size and energy consumption, Camp Zama rates were used to analyze project economics for all five installations.

In the United States, the average, total installed capital cost of a wind energy project has been rising since 2003. Currently, the average capital cost is around $¥ 210,000 / \mathrm{kW}$ (Bolinger 2009) and was $¥ 175,000 / \mathrm{kW}$ in 2007 (the time of the Yokohama installation). Based on the cost for the Yokohama wind turbine, the rise in the average total cost in the U.S. over the years, and the assumption that project costs are about 30\% higher in Japan, a revised capital cost of $¥ 350,000 / \mathrm{kW}$, before taxes, was calculated for this analysis.

The assumptions used are listed in Table B.3. Emissions savings are based on the replacement of electricity generated in Japan, which generates an average of $0.444 \mathrm{~kg}$ of $\mathrm{CO}_{2}$ per $\mathrm{kWh}$ produced (FEPC 2009).

Table B.3: Performance, Cost, and Economic Characteristics

\begin{tabular}{|l|l|}
\hline Location & Kanto Installations, Tokyo Area, Japan \\
\hline Conditions & $\begin{array}{l}\text { Standard: } 1.225 \mathrm{~kg} / \mathrm{m}^{3} \text { density, } 0^{\circ} \mathrm{F}, \\
0 \text { m elevation }\end{array}$ \\
\hline Assumed Average Wind Speed & $5.97 \mathrm{~m} / \mathrm{s}$ at $80 \mathrm{~m}$ \\
\hline Net Capacity Factor & $21.2 \%$ \\
\hline Turbine Type & $1.5 \mathrm{MW}, 77 \mathrm{~m}$ rotor, $80 \mathrm{~m}$ hub \\
\hline Project Size & 1 turbine, $1.5 \mathrm{MW}$ total \\
\hline $\begin{array}{l}\text { Estimated Net Annual Energy } \\
\text { Production }\end{array}$ & $2,787,250 \mathrm{kWh} / \mathrm{yr}$ \\
\hline CO ${ }_{2}$ Emissions Reduction & $1,237,539 \mathrm{~kg}-\mathrm{CO}_{2}$ \\
\hline Energy Charge & $¥ 9.87 / \mathrm{kWh}$ \\
\hline Capital Cost & $¥ 367,500 / \mathrm{kW}$ \\
\hline Fixed O\&M Cost & $¥ 7,800 / \mathrm{kW}$ \\
\hline Transmission Costs & Not Included \\
\hline \hline
\end{tabular}

\section{Findings: Wind}

The wind project costs were evaluated for ECIP eligibility and IPP project potential. Although it is unlikely that an IPP will contractually be able to develop a renewable project for the U.S. Army in Japan, this scenario was analyzed to show an alternative to appropriated funding, which will be difficult to obtain for high-cost projects. Also, the IPP scenario may be representative of a project developed, owned, and operated by GOJ.

To qualify for ECIP funding, a project must achieve an SIR of 1.0, and its payback is also examined. For the IPP evaluation, the commercial cost of energy was calculated to obtain an IRR of $10 \%$. This was used as the minimum IRR required to attract the interest of a wind power project developer. Table B.4 lists the results of this analysis, which shows poor economic potential. 
Table B.4: Economic Assessment of Wind Power

\begin{tabular}{|c|c|c|c||}
\hline $\begin{array}{c}\text { Financing } \\
\text { Scenario }\end{array}$ & \multicolumn{2}{|c|}{ ECIP } & IPP \\
\hline $\begin{array}{c}\text { Economic } \\
\text { Factor }\end{array}$ & SIR & $\begin{array}{c}\text { Simple } \\
\text { Payback } \\
\text { (years) }\end{array}$ & $\begin{array}{c}\text { Cost of Electricity } \\
\text { at 10\% IRR } \\
\text { (¥/kWh) }\end{array}$ \\
\hline Results & 0.32 & 41.2 & 40.26 \\
\hline
\end{tabular}

\section{Wind: Next Steps}

As a result of the area's poor wind resource, unfavorable economics, and limited land space, the Kanto installations should not pursue a wind energy project. Because of siting challenges, it is unlikely a wind turbine will be appropriate for these installations in the future as well.

\section{Wind Sources of Information}

3TIER. 2010. FirstLook. Accessed January 2010 at http://www.3tier.com/firstlook/.

Bolinger M. May 5, 2009. An Update on U.S. Wind Power Prices and the Factors that Influence Them. WINDPOWER 2009 Presentation in Chicago, Illinois. Lawrence Berkeley National Laboratory.

City of Yokohama. September 2006. Newsletter. Provided to PNNL staff by Camp Zama staff during PNNL’s April 2010 site visit.

FEPC-The Federation of Electric Power Companies of Japan. 2009. Environmental Action Plan by the Japanese Electric Utility Industry. September 2009. Accessed May 2010 at http://www.fepc.or.jp/english/library/environmental_action_plan/index.html.

GWEC - Global Wind Energy Council. 2009. Japan. Accessed December 2009 at http://www.gwec.net/index.php?id=123 (last update unknown).

Nakata H. July 9, 2008. Nature stifling wind power in Japan. The Japan Times Online. Accessed December 2009 at http://search.japantimes.co.jp/cgi-bin/nb20080709a1.html.

NASA - National Aeronautics and Space Administration Langley Research Center. 2009. "Surface meteorology and Solar Energy." Atmospheric Science Data Center. Accessed January 2010 at http://eosweb.larc.nasa.gov/sse/ (last update August 28, 2009).

NEDO - New Energy and Industrial Technology Development Organization. 2007. Wind Energy Map of Japan. Accessed January 2010 at http://app2.infoc.nedo.go.jp/nedo/ (last update 2007).

Pacific Northwest Laboratory. 1986. Wind Energy Resource Atlas of the United States. Solar Technical Information Program \& Solar Energy Research Institute. Golden, Colorado. http://rredc.nrel.gov/wind/pubs/atlas/atlas_index.html. 


\section{APPENDIX C}

Analysis of Biomass and Was te-to-E nergy Opportunities 



\section{Appendix C: Analysis of Biomass and Waste-to-Energy Opportunities}

\section{Biomass and Waste-to-Energy Technology}

The term "biomass" refers to renewable fuels used for power production that include agricultural waste, forest and wood processing waste, animal waste, industrial waste, dedicated biomass crops, and methane from landfills and wastewater treatment plants. Waste-to-energy (WTE) is similar, but includes municipal solid waste (MSW) and construction and demolition (C\&D) waste as fuel sources. These feedstocks qualify as renewable sources for Energy Policy Act of 1992 (EPAct) compliance purposes. While biomass and WTE projects may be very different as to their sources, fuel collection modes, and fuel cost profiles, in the end, energy production often relies on similar technologies.

The primary technologies for producing electricity rely upon steam turbines, gas turbines, or combined cycle turbine generators. Generators are energized by steam produced from direct combustion of raw material, or a synthetic gas (syngas) produced through anaerobic digestion or gasification. Direct combustion and anaerobic digestion technologies are mature and have been proven commercially. Gasification technologies are newer in the market, but are promising based on a number of successful installations. Anaerobic digestion is widely used, but primarily for smaller applications in rural and municipal projects rather than large commercial installations.

Combustion systems burn biomass to produce steam in a boiler, turning a turbine connected to a generator. This method of producing electricity is quite inefficient, at about 20 to $30 \%$.

Gasification is more efficient than combustion, but the technologies employed are not as mature or common in commercial operation. Gasification uses oxygen (direct-fired systems only), steam, heat, and pressure to break down organic materials to produce syngas, which is primarily hydrogen and carbon monoxide. Syngas is cleaned to remove impurities, then is used to generate electricity in a gas turbine or fuel cell, or is used to produce transportation fuels and/or commercially valuable chemicals.

Plasma melting is one gasification process newer to the commercial market for use with MSW. There are no commercial operations in the United States, but Japan has a number of plasma facilities. The plasma melter uses a plasma torch to decompose the material being gasified, resulting in a much higher temperature and more complete reaction. This technology produces only syngas from the organics, molten metal from any metals, and a hard glass-like substance from the inorganics. Hazardous materials can also be gasified in this process, sealing the toxic substances into the solid waste with no potential for leaching (EvTEC 2002).

Digesters tend to be smaller systems and are typically used just for biomass. They are usually located at the biomass source, such as farms with significant amounts of animal manure and wastewater treatment facilities. Digesters break down biomass in warm, wet environments to produce methane, which can be captured as fuel for generating electricity. Because of the smaller size of digester systems, electricity is typically generated using fuel cells, microturbines, or reciprocating engines. 
Methane is also produced through anaerobic digestion in landfills as the garbage underground breaks down. The most economic opportunities for landfill methane capture and use are in cases where the landfill already has a collection system in place, is active or recently closed (methane production tapers off as landfills age), and has sufficient waste (typically at least 1 million tons) to generate a significant amount of methane. The landfill must be lined as well, to prevent water intrusion into the landfill that stifles digestion of the waste and methane production and to prevent the methane from migrating into the surrounding soil.

Examples of installed biomass and waste-to-energy facilities in Japan can be found in the PNNL report, Renewable Energy Assessment Methodology for Japanese OCONUS Army Installations (Solana et al. 2010). These examples illustrate that the aforementioned technologies have been utilized successfully in Japan, thus it could be technically feasible to install these systems at the Kanto area installations.

\section{Siting Considerations}

For all of these technologies, except landfill gas, a power plant will require feedstock storage space, feedstock preparation equipment, feed equipment, processing equipment, product cleaning and collection equipment, electricity generation equipment, ash and waste storage space, water for steam and cooling, and emissions control equipment. The specific infrastructure and space required for each of these depends on the type of feedstock and process application, the amount of feedstock used, and existing site conditions. As an example, one plasma gasification project evaluated could process 250 tons of MSW per day in an 80-foot by 175-foot area, not including storage space. However, permanent systems with infrastructure typically need up to 5 acres (excluding feedstock storage).

In addition to sufficient space, a biomass or WTE project will require proximity to a substation if generating electricity (pipeline or thermal load if generating gas, steam, or hot water), truck access for feedstock delivery, and utilities for plant operation. Consideration will also need to be given to the appearance, noise, and odor of the plant; residential and other high-visibility areas should be avoided.

\section{Biomass and Waste-to-Energy Analysis Approach}

The critical factor in determining feasibility for biomass or waste energy generation is feedstock availability. Typically, feedstocks available within a 60-mile radius of the Army installation would be quantified and considered for potential electricity generation using the data sources identified in the PNNL report, Renewable Energy Assessment Methodology for Japanese OCONUS Army Installations (Solana et al. 2010). However, for the Kanto installations, procuring feedstock from offsite sources is not an option because of environmental restrictions. Thus, projects will be deemed feasible only if electricity can be generated economically with onsite biomass or waste sources.

There are a number of potential feedstocks that were evaluated for use at the Kanto installations. In this analysis, if the electricity available from a feedstock was less than $0.5 \mathrm{MW}$, the feedstock was considered infeasible. The narrowed list of possible feedstocks was then evaluated on a simple economic basis. Feedstock costs were estimated based on tipping fees, collection costs, 
transportation costs, current market rates, and other relevant information. Other operational costs and construction costs were estimated by scaling existing plant data for the primary technology types. Based on the amount of feedstock available and the size of plant required, a levelized cost of electricity was estimated for each. The Kanto installations' average electricity cost of $¥ 13.57 / \mathrm{kWh}$ was used as the target cost of electricity for this economic analysis, for all installations.

PNNL staff created a new tool that supports analyses of various plant sizes, costs, and fuel sources in a generic manner. This facilitates "what if" analyses where critical information about fuel source and cost is unavailable. The result is an estimate of what power from a project would cost using available data and staff assessments for missing data. It also allows staff to reverse engineer an answer using the Kanto area installations’ power cost as a given. Specifically, the tool can be set up to provide an estimate of what size plant and fuel cost is needed to produce power for less than the current and projected future power rate. Data from a 2003 National Renewable Energy Laboratory (NREL) study of biomass fuels was used to initiate the analytic tool (Bain et al. 2003). The 2003 study costs were converted into 2010 dollars and scaled according to varying plant sizes following the methodology used in the study. Any size plant can be evaluated and any value can be varied to test for financial feasibility. The tool was only used for preliminary screening, as it does not adequately address taxes, incentives, or other factors. These economic factors can have a significant impact on project feasibility.

If the preliminary screening analysis resulted in highly uneconomic estimated costs, the option was rejected. For any options that appeared to be reasonably close to cost-effective in the screening tool, further economic analysis was completed, including evaluating taxes, incentives if available, different financing options, and ranges of feedstock sources and amounts. Any risks or potential issues associated with these remaining project options were noted, to present all considerations surrounding an implementation decision. When possible, these were quantified.

\section{Biomass and Waste Resource Characterization}

The following biomass and waste types were assessed for potential as feedstocks.

- Agricultural (crop residues, animal waste, dedicated biomass crops)

- Forest (thinnings, logging slash)

- Industrial (mill residue, other industry waste)

- Waste (MSW, landfill gas, biogas or biosolids from wastewater treatment plants)

\section{Agricultural Biomass}

\section{Crop Residue}

Crop residues are the plant remains in the field after harvest. Some crops have more residues than others; some, like hay, have no residues at all because the entire plant is harvested. A certain amount of residue left on the soil minimizes erosion and maintains nutrients in the soil, and can provide habitats for game animals. However, too much residue can inhibit growth of a new crop. Depending on tilling practices, climate, crop type, soil type, and slope of the land, residue may or may not be available for removal. In general, conventional till practices need 
more residue than no-till practices; warm wet climates need more residue than cold dry climates; corn fields need more residue than wheat fields; coarse, well-drained soils need more residue than poorly-drained, heavy clay soils; and steeper slopes need more residue than flat land. In addition, crop residue availability is dependent on competing uses, like cattle feed, and seasonal yields, which can change dramatically from year to year.

No crops are cultivated on any of the Kanto installations, thus using crop residue as a fuel source for energy production is not an option. Furthermore, farms in Japan tend to be small rather than industrial, so an offsite biomass plant would not likely be practical.

\section{Animal Waste}

Manure from cattle, swine, and poultry farms is generally reclaimed from animal housing and feeding areas and used as fertilizer for crops. This has become a problem because of overapplication. Bad odors and groundwater contamination are forcing farmers to find other ways to dispose of manure. Furthermore, greenhouse gas emissions are now more strictly regulated, so emissions from manure must be controlled. Anaerobic digestion technologies can turn wet manure into energy, and often can be used with existing collection and treatment systems. Poultry waste can be used directly in combustion or gasification systems because it has lower moisture content than cow or swine manure.

No animals are contained on any of the Kanto installations, thus using animal waste as a fuel source for energy production is not an option. Furthermore, farms in Japan tend to be small rather than industrial, and animals are typically left in pastures rather than feedstalls, so an offsite digester would not likely be practical either.

\section{Dedicated Crops}

The most common dedicated energy crops include switchgrass, hybrid poplar, willow coppice, and other short rotation woody crops (SRWC). Energy crops are fast-growing plants that can be harvested for use as energy in various forms. Switchgrass is a native prairie grass that grows best in warm dry climates like the Midwestern United States. SRWC need lots of water and do well in colder climates like the Northeastern United States. They need at least 16 inches of rainfall per year, or need to be located on a body of water. Using dedicated crops as biomass is an option, but they are not always a readily available resource. Rather, agricultural land where the crops can be grown is the resource to be evaluated, and the feedstock cost would be based on the cost to farm that land, harvest the resource, and deliver it to the generation plant on post.

Due to limited land area on all of the Kanto installations, utilizing dedicated energy crops as a fuel source for energy production is not an option.

\section{Forest Thinnings and Logging Slash}

Logging slash includes branches, stumps, and other material that is generated during logging practices but left behind because it is not useful to the loggers seeking large tree trunks. Once this slash is cut and left on the forest floor, it dries out, becoming good fuel for fires. It also can get in the way of machinery during replanting efforts. Sometimes it is gathered into small piles and burned in a controlled manner to reduce the risk of widespread forest fire, but this practice pollutes the air and may be restricted by air quality regulations. Instead, it can be collected and 
transported to a biomass facility where the emissions can be controlled and the wood waste can be used to generate energy.

There are no active timber harvesting operations on any of the Kanto installations, thus using logging slash as a fuel source for energy production is not an option. Furthermore, there is minimal logging in all of Japan. Logs are shipped from the United States, and pulpwood is shipped from South America. Therefore an offsite biomass plant utilizing woody waste would not likely be feasible either.

\section{Industrial Biomass}

Industrial biomass includes mill residue, food processing waste, textile waste, or waste from other specialized operations.

There are no mills or large industrial facilities on or near any of the Kanto area installations.

\section{Waste Biomass}

\section{Municipal Solid and Urban Wood Waste}

Due to limited land availability for landfills in Japan, incineration (combustion) is the most common method for waste disposal. About $70 \%$ of all waste incineration facilities used heat recovery for steam, electric power generation, or other uses (MOE 2009).

The Kanto area installations produce approximately 5,055 tons of MSW per year. Waste generation by site is shown in Table C.1. This waste is either sent to offsite incinerators managed by local Japanese entities, or sent to an incinerator located on Camp Zama.

Table C.1: Waste Generated at Kanto Installations

\begin{tabular}{|c|c|c|c|c|c|c|c|}
\hline \multirow[b]{2}{*}{ Site } & \multicolumn{3}{|c|}{ Waste Incinerated Offsite } & \multicolumn{3}{|c|}{ Waste Incinerated at Camp Zama } & \multirow[b]{2}{*}{$\begin{array}{c}\text { Potential } \\
\text { Electricity } \\
\text { Generation } \\
\text { (MW) } \\
\end{array}$} \\
\hline & $\begin{array}{c}\text { Tipping } \\
\text { Fee } \\
\text { (¥/ton) }^{1}\end{array}$ & $\begin{array}{l}\text { Assumed } \\
\text { Cost } \\
\text { Savings } \\
\text { (¥/ton) }{ }^{2}\end{array}$ & $\begin{array}{c}\text { Available } \\
\text { MSW } \\
\text { (tons/year) }\end{array}$ & $\begin{array}{c}\text { Tipping } \\
\text { Fee } \\
\text { (¥/ton) }\end{array}$ & $\begin{array}{l}\text { Assumed } \\
\text { Cost } \\
\text { Savings } \\
\text { (¥/ton) }^{3}\end{array}$ & $\begin{array}{c}\text { Available } \\
\text { MSW } \\
\text { (tons/year) }\end{array}$ & \\
\hline Akasaka Press Center & \multirow{5}{*}{$¥ 11,400$} & \multirow{5}{*}{$¥ 8,550$} & 73 & \multirow{5}{*}{$¥ 18,010$} & \multirow{5}{*}{$¥ 0$} & 0 & 0.008 \\
\hline $\begin{array}{l}\text { Yokohama North } \\
\text { Dock }\end{array}$ & & & 128 & & & 0 & 0.014 \\
\hline Camp Zama & & & 1,601 & & & 1,265 & \multirow{3}{*}{0.53} \\
\hline $\begin{array}{l}\text { Sagamihara Family } \\
\text { Housing Area }\end{array}$ & & & 754 & & & 696 & \\
\hline Sagami General Depot & & & 107 & & & 432 & \\
\hline & & TOTAL & 2,663 & & & 2,393 & 0.56 \\
\hline
\end{tabular}

${ }^{1}$ Calculated based on total contracted solid waste cost for Kanto installations of $¥ 77,960,000 /$ year. Includes operation and maintenance costs for the Camp Zama incinerator, thus the tipping fee for waste incinerated at Camp Zama was assumed to be $25 \%$ more than waste incinerated offsite.

${ }^{2}$ Discounted $25 \%$ from the tipping fee to account for any additional transportation costs.

${ }^{3}$ Assumed Cost Savings for waste incinerated at Camp Zama is zero, since operating, maintenance, and transportation costs would still remain if WTE technology was integrated into the existing incinerator. 
The Camp Zama incinerator is in operation only because the local authority refuses to accept the U.S. Army waste generated within their boundaries, for fear of contaminating their local incinerator. Camp Zama does not have the space for a large landfill, and so operating the incinerator is their only option for waste disposal. The incinerator is past its life expectancy (built in 1985) and uses outdated emissions control equipment, producing more than an acceptable amount of greenhouse gases, hazardous ash waste, and other pollutants. An alternative is needed, but a feasible solution has yet to be found.

Akasaka Press Center (PC) and Yokohama North Dock (ND) do not generate enough waste to sustain a WTE plant on their own. Because of the location of these sites, transporting waste to contribute to the other installations' waste for incineration in the existing facility or a new WTE facility would be uneconomic.

Camp Zama, Sagamihara Family Housing Area (SFHA), and Sagami General Depot (Sagami Depot) are all located in Sagamihara City, and about half of the combined waste for the three sites is incinerated in the existing incinerator at Camp Zama. The remaining waste is sent to local offsite facilities. While the Camp Zama incinerator does not currently utilize energy generation technologies, capital costs for conversion would be less than building a new WTE facility. The conversion could also include upgraded emissions control equipment and efficiency improvements. All waste from the three sites could be used as a fuel source to generate up to 0.5 MW of electricity.

Commercial C\&D waste is often primarily comprised of concrete, asphalt, or other materials that do not break down easily, thus it is typically not available for energy generation. The small amount of C\&D waste generated at the Kanto installations is already separated and recycled, and not available for energy generation.

The technologies considered for waste conversion at Camp Zama include combustion and gasification. See the Findings section below for the economic analysis of using MSW from Camp Zama, SFHA, and Sagami Depot for electricity generation.

\section{Landfill Gas}

Methane generated from decomposing waste is a combustible pollutant that must be controlled. It is typically vented or collected and flared to avoid buildup and danger of explosion. Collected methane can be used as a fuel to generate heat or electricity.

Two landfills exist on the Kanto installations, one at Sagami Depot and one on Camp Zama. The landfill at Sagami Depot has been closed for 25 years, so the amount of methane generated at this location is likely insufficient for economic capture and use. However, methane concentrations of over $50 \%$ have been noted in the soil gas at 3 wells. The volume of this gas is unknown, but if the total landfill gas generation is at least 18,500 thousand cubic feet (kcf) per year, a 100-kW generator could be economically powered by this gas. Based on Sagami Depot's current waste generation of about 540 tons per year and an assumption of 45 years of operation, a maximum landfill gas generation amount of about 5,000 kcf/year could be expected, with current amounts closer to 1,500 kcf/year. A much larger landfill would be needed for economic use of landfill gas. 
The primary material disposed of at the Camp Zama landfill is ash from the incinerator, which does not produce methane in the decomposition process. As a result, landfill gas is not an option for electricity generation.

\section{Wastewater Treatment Plant Sludge}

Wastewater treatment plant (WWTP) sludge is what remains after wastewater is treated and the clean water is returned to the ground or other body of water. It has high energy content when dried, but the drying process is energy-intensive and necessary before transportation. Sludge is similar in substance to manure; it is very watered-down and best processed on site, where methane is generated with anaerobic digestion. Therefore, only on-site sources of sludge are reasonable to use for energy generation.

There is one WWTP on the Kanto installations, at Camp Zama. To produce 1 MW of power, the annual production of sludge needs to exceed 13,400 tons. Sludge treated in an anaerobic digester becomes cost-effective (with a liberal assumption of no cost for the feedstock) at about $20 \mathrm{MW}$, which would require over 260,000 tons of sludge per year. Considering that New York City produces 143,810 tons of sludge per year, Camp Zama is nowhere near this sludge requirement. Therefore, WWTP sludge is not a feasible resource.

\section{Biomass and Waste-to-Energy: Economic and Other Analysis Parameters}

Data used in this analysis were obtained from local sources when possible, and the economic assumptions were generally conservative. However, any significant changes to important assumptions may change outcomes-opportunities that are just barely economic in this report may no longer be economic if the values are changed significantly. These include tipping fees, waste transportation costs, capital costs, and operations and maintenance (O\&M) costs.

Biomass and WTE options were analyzed using Energy Conservation Investment Program (ECIP) and independent power producer (IPP) funding scenarios. Although it is unlikely that an IPP will contractually be able to develop a renewable project for the U.S. Army in Japan, this scenario was analyzed to show an alternative to appropriated funding, which will be difficult to obtain for high-cost projects. Also, the IPP scenario may be representative of a project developed, owned, and operated by the Government of Japan (GOJ).

Cost-effectiveness for ECIP projects is determined with savings-to-investment ratio (SIR) values (greater than 1.0), and the internal rate of return (IRR) shows whether the IPP scenario is costeffective (greater than 10\%). The economic assumptions used to analyze each scenario are listed in Table C.2. There are no incentives available for a biomass or WTE project in Japan. The assumptions that vary per scenario are listed below with the results. The average cost of electricity that Kanto installations would pay for the renewable energy was assumed to be $¥ 13.57 / \mathrm{kWh}$. 
Table C.2: Economic Assumptions

\begin{tabular}{|r|l|r|}
\hline \hline \multicolumn{2}{|l|}{ Economic Factors } & \\
\hline & Inflation & $1.2 \%$ \\
\hline & Interest Rate & $10.0 \%$ \\
\hline & Debt/Equity Ratio & N/A \\
\hline & Real Discount Rate & $3.0 \%$ \\
\hline Tax Considerations & \\
\hline & Prefectural Tax Rate & $38.1 \%$ \\
\hline & Prefectural Income Tax Rate & $5.6 \%$ \\
\hline & Prefectural Sales Tax & $1.7 \%$ \\
\hline & Property Tax Rate & \\
\hline \multicolumn{1}{|l|}{ Technology } & 30 years \\
\hline & Plant Life & \\
\hline & $\begin{array}{l}\text { Capacity Factor (basis net kW } \\
\text { output): Total System }\end{array}$ & \\
\hline \hline
\end{tabular}

\section{Findings: Biomass and Waste-to-Energy Opportunities}

The availability of crop residue, animal waste, dedicated energy crops, logging residue, industrial waste, landfill gas, and WWTP sludge is inadequate to consider a biomass generation project.

MSW, on the other hand, could be a viable option for generating electricity at Camp Zama. Camp Zama's waste, combined with waste from the neighboring SFHA and Sagami Depot, was evaluated for economic feasibility as a new combustion or gasification WTE project.

Combustion was the more cost-effective scenario; the results are presented in Table C.3. 
Table C.3: Results for a New WTE Plant at Camp Zama

\begin{tabular}{|l|c|}
\hline \multicolumn{1}{|c|}{ Waste Source } & $\begin{array}{c}\text { Camp Zama, } \\
\text { SFHA, Sagami } \\
\text { Depot }\end{array}$ \\
\hline Technology & Combustion \\
\hline Plant Size & $0.5 \mathrm{MW}$ \\
\hline Feedstock Amount & 4,854 tons/yr \\
\hline Total Plant Cost & $¥ 644,860 / \mathrm{kW}$ \\
\hline \multicolumn{1}{|c|}{ Capital Cost } & $¥ 614,160 / \mathrm{kW}$ \\
\hline \multicolumn{1}{|c|}{ Sales Tax } & $¥ 30,710 / \mathrm{kW}$ \\
\hline Fixed O\&M Cost & $¥ 116,290 / \mathrm{kW}$ \\
\hline Variable O\&M Cost & $-¥ 3.8 / \mathrm{kWh}$ \\
\hline \multicolumn{1}{|c|}{ Feedstock Cost } & $-¥ 4,390 / \mathrm{ton}$ \\
\hline SIR & \multicolumn{1}{c|}{0.1} \\
\hline Simple Payback & 67 years \\
\hline $\begin{array}{l}\text { Cost of Electricity at 10\% } \\
\text { Internal Rate of Return } \\
\text { (IRR), No Financing }\end{array}$ & $¥ 26.9 / \mathrm{kWh}$ \\
\hline
\end{tabular}

The economics listed in Table C.4 correspond to the costs required for constructing and operating a new WTE plant. Largely due to the high taxes and small scale of the plant, it is not recommended to pursue WTE using new construction. However, if the existing incinerator is retrofitted with WTE technology, the total plant cost will be lower and the resulting economics more favorable. Plant upgrades that are needed regardless could be considered a sunk cost. Furthermore, because this would be a retrofit, it would be funded through IMCOM, rather than through Japanese funding sources. This improves the chances of receiving funding, especially through appropriated sources like ECIP.

Obtaining exact costs for retrofitting the incinerator was beyond the scope of this assessment, but assuming the same tipping fees, waste transportation costs, and O\&M costs, the total plant cost (including taxes) required to produce electricity at a cost comparable to the Kanto installations' current cost of electricity is $¥ 466,800 / \mathrm{kW}$. It is recommended to further investigate the cost and practicality of retrofitting the existing WTE plant.

Another potential option for disposing the waste currently incinerated at Camp Zama is to send it to the new incinerator owned by Sagamihara City and located adjacent to Camp Zama. The new incinerator was built to replace the smaller, old incinerator and is providing heat to the neighboring swimming pool, public bathhouse, and greenhouse, as well as power for onsite use and sale to the Tokyo Electric Power Company (TEPCO). This incinerator utilizes state-of-the- 
art WTE technology, and it is theoretically possible that an equivalent amount of renewable energy, about 2,020 MWh/year, could be credited to Camp Zama according to the amount of MSW contributed. Because greenhouse gas emissions from the current Camp Zama incinerator are problematic, shutting it down completely and sending all waste offsite could be advantageous.

The amount of greenhouse gas emissions that the existing Camp Zama incinerator currently emits is unknown; however, it is not insignificant and it has historically been challenging to ensure the facility meets Japanese emissions requirements. Either of the options identified above, converting the incinerator to a WTE facility or sending all MSW to the offsite Sagamihara City incinerator, would result in reduced emissions for the site.

If the onsite incinerator was converted to a WTE facility and approximately 3,980 MWh/yr was produced onsite rather than purchased from the local utility, annual emissions for Camp Zama could be reduced by a minimum of 1,700 tons of $\mathrm{CO}_{2} /$ year. This assumes existing electricity purchased by Camp Zama has an associated emissions factor of $0.444 \mathrm{~kg} \mathrm{CO}_{2} / \mathrm{kWh}$ (FEPC 2009). Furthermore, because converting the onsite incinerator to a WTE facility would include upgrading the emissions control equipment, emissions could be further reduced from the amount currently emitted by the incinerator.

Alternatively, sending all MSW offsite and shutting down the incinerator would eliminate all emissions from the onsite incinerator. Further emissions reductions could be realized, depending on how the emissions factor for generating electricity from the Sagamihara City incinerator compares to the national average electricity generation emissions factor.

\section{Biomass and Waste-to-Energy: Next Steps}

Retrofitting the existing incinerator to generate electricity could be a feasible option for Camp Zama, and should be explored. The following steps must occur to implement a WTE retrofit project.

- Gain support from stakeholders at Camp Zama, U.S. Forces Japan (USFJ), GOJ, the Japan Engineering District (JED), and TEPCO, as appropriate. Meet with all interested parties, and assign roles and responsibilities.

- Quantify the amount of MSW that is actually available for use in a WTE facility on Camp Zama, and verify what tipping fee(s) will accompany the waste.

- Confirm actual capital and O\&M costs, and associated taxes for retrofitting the incinerator.

- Determine the source of financing for the project.

- Complete a legal and regulatory review to determine whether the upgrades can be made, given the contractual and political situation of the installations in Japan.

- Identify emissions limits and other environmental concerns; ensure a WTE plant can meet the requirements. 
To send MSW to the new offsite incinerator and claim renewable energy credit, a number of items will have to be addressed. These include:

- Determine whether Camp Zama's waste will be accepted at the new Sagamihara City incinerator, and if so, what standards must be met.

- Discuss the existing contract with TEPCO and determine whether a renewable energy clause could be added.

- Determine whether a direct transmission line from the Sagamihara City incinerator to Camp Zama is needed to claim renewable energy consumption.

- Establish additional MSW separation and recycling programs to ensure that the MSW sent offsite meets the standards of the Sagamihara incinerator.

- Identify supplementary costs that may be required for transportation to and disposal at the Sagamihara City incinerator, and evaluate economics.

The benefits and challenges of each of the above options should be considered carefully to identify which option is best for the Kanto installations. Both should be pursued until one is determined to be infeasible or disadvantageous, at which point it should be eliminated from consideration.

\section{Biomass and Waste-to-Energy Sources of Information}

Bain, RL, WA Amos, M Downing, RL Perlack. 2003. “Biopower Technical Assessment: State of the Industry and Technology.” National Renewable Energy Laboratory. NREL/TP-51033123. March 2003.

EvTEC - Environmental Technology Evaluation Center. 2002. "Environmental Technology Verification Report for the Plasma Enhanced Melter.” Civil Engineering Research Foundation. December 2002.

FEPC-The Federation of Electric Power Companies of Japan. 2009. Environmental Action Plan by the Japanese Electric Utility Industry. September 2009. Accessed May 2010 at http://www.fepc.or.jp/english/library/environmental_action_plan/index.html.

MOE - Japan Ministry of the Environment. 2009. Annual Report on the Environment and the Sound Material-Cycle Society in Japan 2009 (General Summary of "Sound Material-Society" Section). Accessed February 2010 at http://www.env.go.jp/en/recycle/smcs/arep/2009gs_full.pdf.

Solana, AE, WJ Gorrissen, JR Hand, JA Horner, AR Kora, AC Orrell, BJ Russo, MR Weimar, and JL Williamson. 2010. Renewable Energy Assessment Methodology for Japanese OCONUS Army Installations. Pacific Northwest National Laboratory, Richland, Washington. 
C-12 


\section{APPENDIX D}

Analys is of Geothermal Plant Opportunities 



\section{Appendix D: Analysis of Geothermal Power Plant Opportunities}

\section{Geothermal Power Technology}

Geothermal power plants use steam from hot water reservoirs found deep below the Earth's surface. The steam rotates a turbine that activates a generator, producing electricity. There are three commercial types of geothermal power plants used to generate electricity (dry steam, flash steam, and binary cycle), and several newer technologies are entering the marketplace (hot dry rock and engineered geothermal systems). The type of plant depends on the state of the fluid (whether it is steam, hot water, or mixed) and its temperature. This analysis focuses on binary cycle systems, which are commercial technologies that do not require extremely high temperatures.

Binary cycle power plants utilize a second fluid in a closed cycle to operate the turbine, instead of direct geothermal steam. These plants operate on water at temperatures of about $225-360^{\circ} \mathrm{F}$ $\left(107-182^{\circ} \mathrm{C}\right)$. The heat from the hot water is used to boil a working fluid, usually an organic compound with a low boiling point. The working fluid is vaporized in a heat exchanger and used to turn a turbine. The water is then injected back into the ground to be reheated. The water and the working fluid are kept separated during the whole process, so there is minimal or no contamination. The advantage of the binary cycle plant is that it can operate with lower temperature water by using working fluids that have an even lower boiling point than water. Binary power plants are available in smaller scales such as $200 \mathrm{~kW}$ to $1 \mathrm{MW}$.

Japan has nearly 200 volcanoes, which are associated with geothermal energy resources. Japan is currently operating 20 geothermal power plants in 18 locations nationwide. Total net output from the plants is approximately $535 \mathrm{MW}$, equating to about $0.2 \%$ of Japan's total power capacity (Kawazoe and Combs 2004).

One major obstacle to further development of geothermal resources for power production in Japan is that many of the most attractive areas in terms of resource potential are located in protected areas in national parks or quasi-national parks where such development is prohibited (Koshiba 2009). Compliance with the many Japanese requirements such as the Hot Springs Act, the Environmental Impact Assessment Act, the Electricity Utilities Industry Law, and others restrict access and increase the cost of both development and electricity generation.

In addition to regulatory obstacles, development is often opposed by tourism industries concerned with possible degradation of hot springs, which are visited by travelers and locals alike. However, a long history of geothermal power production has provided knowledge of how to develop geothermal power generation projects without impacting hot springs, although public opinion does not necessarily reflect that knowledge.

\section{Geothermal Power Analysis Approach}

The baseline analysis for a geothermal resource assumes a binary cycle power plant. Binary plants utilize lower temperature resources than some other technologies. Given the number of 
geothermal power plants already in operation in Japan, it is likely that the remaining available resources will be at lower temperatures. For preliminary analysis to generate economic data, a 5 MW plant was assumed. A geothermal plant could be sized to match installation load if the resource is found to be viable for power production.

Analysis of geothermal energy generation potential consists of the following steps.

- Identify geothermal potential-Use Japanese sources to determine temperature gradients and heat flow near installations.

- Determine utility perspective-Obtain electric rate tariff information, evaluate applicable regulations, and identify grants, incentives, and other support.

- Develop project economics-Determine project capital investment requirements and project operations and maintenance costs, and calculate the economic value of expected electric production based on selected solar technology and market prices.

\section{Geothermal Power Resource Characterization}

For commercial use, it is necessary to have a geothermal reservoir capable of providing hydrothermal (hot water and steam) resources with sufficiently high flow rates. Successful geothermal electrical power generation requires fluid flow rates equal to or greater than 1,000 gallons per minute (gpm) per MW. Heat flow values above $80 \mathrm{~mW} / \mathrm{m}^{2}$ are considered characteristic of a viable geothermal resource. Productive heat flows are generally greater than $150 \mathrm{~mW} / \mathrm{m}^{2}$ (Blackwell et al. 2003). In addition to sufficiently high flow rates, utility-grade geothermal energy requires temperatures in excess of $212^{\circ} \mathrm{F}\left(100^{\circ} \mathrm{C}\right)$ at depths less than $3 \mathrm{~km}$.

Figure D.1 shows the temperature gradient near the Kanto installations to be in the range of 15 to $30^{\circ} \mathrm{C} / \mathrm{km}$ and the resource temperature to be in the range of 65 to $90^{\circ} \mathrm{C}$ at a depth of $3 \mathrm{~km}$ (GSJ 2009, Tanaka et al. 2004). The wells located closest to the Kanto installations are listed in Figure D.1 with their respective geothermal resource data (Tanaka et al. 2004). 


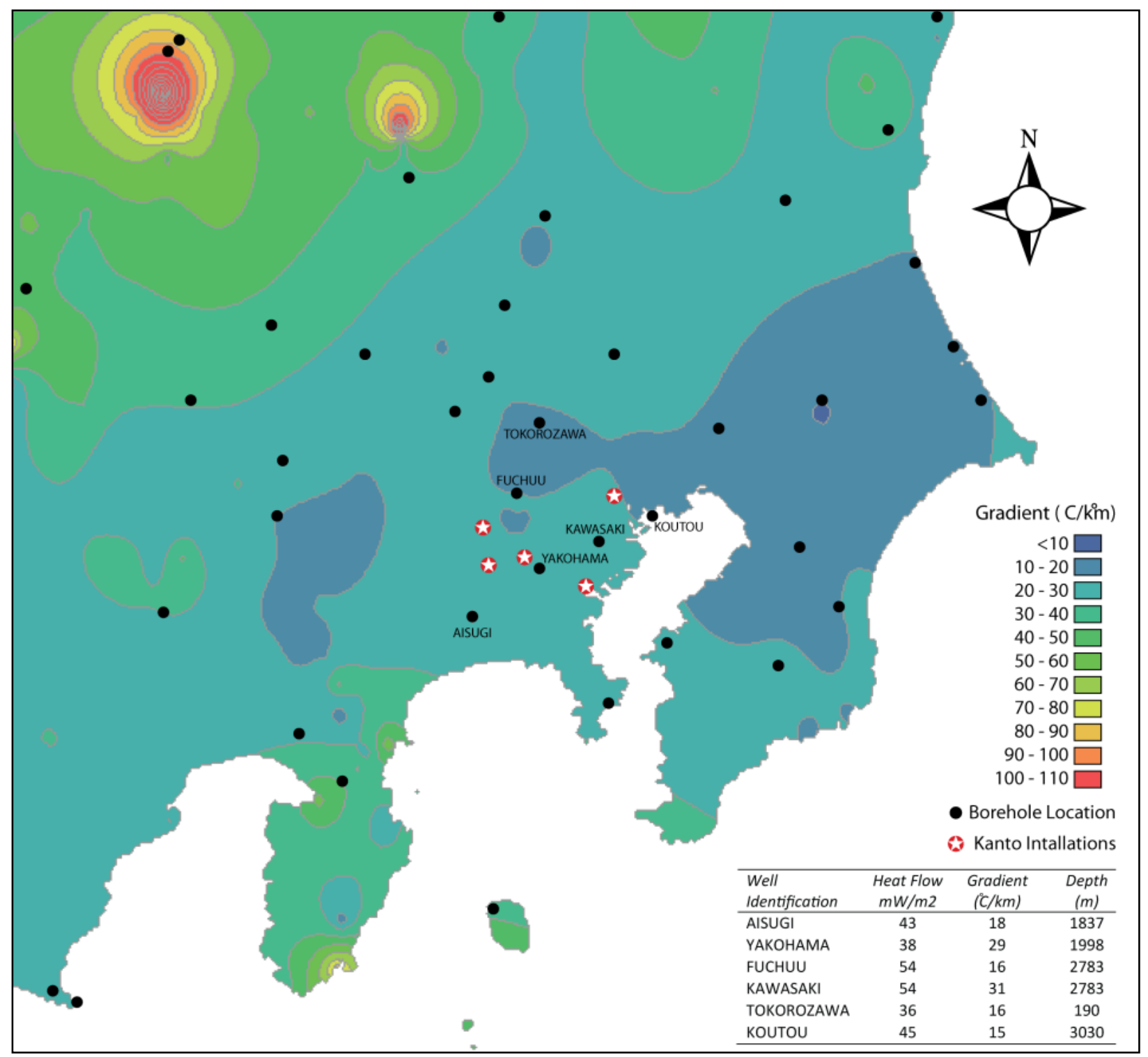

Figure D.1: Boreholes and Well Data near the Kanto Installations

\section{Geothermal Power: Economic and Other Analysis Parameters}

Geothermal power costs are influenced by capital costs for land, drilling, and the physical plant. Capital costs range from $¥ 150,000$ to $¥ 400,000$ per installed kW. Plant life spans are typically 30 to 45 years.

Capital costs include:

- Initial development work: land leasing, exploration, permitting, test well costs

- Infrastructure: roads, water supply, utilities

- Well field drilling: production wells in addition to already drilled confirmation wells

- Steam and brine gathering system: pipes and brine separation equipment 
- Power plant: physical equipment for energy conversion, including substation

- Interconnection: link of the power plant substation to the transmission corridor

- Soft costs: developers' fees, overhead, financing costs, legal fees, etc.

Geothermal wells are typically drilled to depths of 200 to 1,500 meters for low- and mediumtemperature systems, such as the binary systems analyzed here. For high-temperature systems, wells are drilled 700 to 3,000 meters deep. Each well costs $¥ 100$ million to $¥ 400$ million to drill and a geothermal field may consist of between 10 and 100 wells.

The project cost is also affected by the cost of operation and maintenance (O\&M), the amount of power generated, and the market value of the power. Operating costs range from $¥ 0.4$ to $¥ 2.6 / \mathrm{kWh}$ for conventional geothermal power plants (Shibaki 2003, Hance 2005). Larger plant size means lower per-kWh operating costs. Typically, newly constructed geothermal plants operate with a capacity factor between $95 \%$ and $98 \%$ (Hance 2005). Table D.1 lists the economic characteristics used in this analysis. The average cost of electricity that Kanto installations would pay for the renewable energy was assumed to be $¥ 13.57 / \mathrm{kWh}$.

Table D.1: Performance, Cost, and Economic Characteristics

\begin{tabular}{|l|l|}
\hline Location & Kanto installations, Tokyo, Japan \\
\hline Assumed Temperature at 3,000 $\mathbf{~}$ & 50 to $75^{\circ} \mathrm{C}$ \\
\hline Net Capacity Factor & $96 \%$ \\
\hline Technology Type & Binary Plant \\
\hline Project Size & $5 \mathrm{MW}$ \\
\hline Estimated Net Annual Energy Production & $42,077,000 \mathrm{kWh} / \mathrm{yr}$ \\
\hline $\mathbf{C O}_{2}$ Emissions Reduction & $18,682,188 \mathrm{~kg}-\mathrm{CO}_{2}$ \\
\hline Total Capital Cost & $¥ 1,870,200 / \mathrm{kW}$ \\
\hline Transmission Costs & Not Included \\
\hline
\end{tabular}

\section{Findings: Geothermal Power}

The geothermal plant scenario was evaluated for ECIP eligibility and IPP project potential. Although it is unlikely that an IPP will contractually be able to develop a renewable project for the U.S. Army in Japan, this scenario was analyzed to show an alternative to appropriated funding, which will be difficult to obtain for high-cost projects. Also, the IPP scenario may be representative of a project developed, owned, and operated by the Government of Japan (GOJ).

To qualify for ECIP funding, a project must achieve a savings-to-investment ratio (SIR) of 1.0, and its payback is also examined. For the IPP evaluation, the commercial cost of energy was calculated to obtain an internal rate of return (IRR) of $10 \%$. This was used as the minimum IRR required to attract the interest of a project developer. Table D.2 lists the results of this analysis, which does not show good potential. 
Table D.2: Economic Assessment of Geothermal Power

\begin{tabular}{|c|c|c|c||}
\hline $\begin{array}{c}\text { Financing } \\
\text { Scenario }\end{array}$ & \multicolumn{2}{|c|}{ ECIP } & IPP \\
\hline $\begin{array}{c}\text { Economic } \\
\text { Factor }\end{array}$ & SIR & $\begin{array}{c}\text { Simple } \\
\text { Payback } \\
\text { (years) }\end{array}$ & $\begin{array}{c}\text { Cost of Electricity } \\
\text { at 10\% IRR } \\
\text { (¥/kWh) }\end{array}$ \\
\hline Results & 0.51 & 25.4 & 38.34 \\
\hline
\end{tabular}

\section{Geothermal Power: Next Steps}

As a result of the installations' poor geothermal resource, unfavorable economics, and limited land space, as well as local opposition to development of high-temperature resources for energy generation, the Kanto installations should not pursue geothermal energy projects.

\section{Geothermal Power Sources of Information}

Blackwell, D, et al. 2003. Geothermal Resource Analysis and Structure of Basin and Range Systems, Especially Dixie Valley Geothermal Field, Nevada. Department of Geological Sciences Southern Methodist University. Accessed February 2010 at http://www.osti.gov/energycitations/servlets/purl/813485-smnwbs/native/813485.pdf.

Denki, Shimbun. August 7, 2009. "Fuji Electric Systems to pursue over 50\% global market share in geothermal facilities.” Accessed March 2010 at http://www.shimbum.denki.or.jp/english/article/2009080702.shtml.

GSJ_Geological Survey of Japan. 2009. Geothermal Potential Map in Japan. Digital Geoscience Map GT-4. CD purchased January 2010 at http://www.gsj.jp/Map/index_e.html.

Hance, Cedric Nathanael. "Factors Affecting Costs of Geothermal Power Development." Geothermal Energy Association. August 2005. Accessed June 2010 at http://geoenergy.org/reports.aspx.

Kawazoe, S and J Combs. March/April 2004. “Geothermal Japan History and Status of Geothermal Power Development and Production.” Geothermal Resources Council GRC Bulletin. Accessed February 2010 at http://www.geothermal.org/articles.html.

Koshiba, K. December 2009. “Current Status and Future Prospects of Geothermal Energy Use in Japan.” Japan for Sustainability, 88. Accessed February 2010 at http://www.japanfs.org/en/mailmagazine/newsletter/pages/029640.html.

Shibaki, Masashi. 2003. “Geothermal Energy for Electric Power.” A Renewable Energy Policy Project (REPP) Issue Brief. December 2003. Accessed May 2010 at www.repp.org/articles/static/1/binaries/Geothermal_Issue_Brief.pdf.

Tanaka, A, M Yamano, Y Yano, and M Sasada. 2004. Geothermal Gradient and Heat Flow Data in and Around Japan. Earth Planets Space, 56, 1191-1194. 
D-6 


\section{APPENDIX E}

Analys is of Ground Source Heat Pump Opportunities 



\section{Appendix E: Analys is of Ground Source Heat Pump Opportunities}

\section{Ground Source Heat Pump Technology}

Ground source heat pumps (GSHPs) use the stable temperatures of the earth and groundwater to improve the coefficient of performance of heating and cooling applications for buildings. Common GSHP configurations include open-loop, horizontal closed-loop, and vertical closedloop.

To install GSHPs at a building, the surrounding area will have certain prerequisites, depending on the type of GSHP. Open-loop GSHPs need a water source and sink. The source can be a well or open body of water. After the energy transfer has occurred, the water can be rejected to a secondary well, the open body of water used as the source, another body of water, or a storm drain. Water volume requirements depend on the size of GSHP installed, but typically between 1.5 and 3.0 gallons per minute are needed per cooling ton. This high water use greatly affects the feasibility of open-loop systems in some areas, as do local codes and regulations. Many locales do not want to risk groundwater depletion or contamination.

Horizontal closed-loop GSHPs have a different limiting factor: sufficient land area. The heat transfer for these systems occurs in pipes laid in trenches that are between 100 and 400 feet long per cooling ton, spaced between 6 and 12 feet apart and about 6 feet deep. The soil characteristics and number of pipes per trench determine the pipe length; more pipes (up to six) per trench save land space but require more piping per ton of cooling capacity. The trenching costs make horizontal ground loops more expensive to install than open loop systems, but if water availability is the only limiting factor, these systems tend to be the most economic.

Where significant land area and water volume is not available, vertical closed-loop GSHPs may be the only option. In these systems, the heat transfer pipes are placed vertically in the ground at depths of between 75 and 300 feet. Some land area is still required, because the pipe wells need to be spaced at least 15 to 20 feet apart, and 200 to 600 feet of piping are needed per cooling ton. Vertical ground loop systems tend to have the highest first cost of all the GSHP systems because of the cost of drilling multiple bore holes.

The tradeoff between land use, water use, and first cost generally determine which GSHP is appropriate for a particular building. All of these factors need to be taken into account when planning to deploy a GSHP system.

The heat transfer pipes for horizontal and vertical closed-loop systems are made out of highdensity polyethylene (HDPE), a high-strength plastic. Because HDPE is durable, ductile, and flexible, it is often recommended for various underground pipelines in areas prone to earthquakes. These properties should make HDPE suitable for horizontal GSHP applications in areas prone to earthquakes. HDPE's material properties also apply to vertical systems. Though there is less research on the use of HDPE in vertical wells in areas prone to earthquakes, there are many examples of successful vertical wells in Japan. While cases of earthquake-damaged GSHP tubes were not found, care should be taken when designing well depths and configurations in Japan. 


\section{Ground Source Heat Pump Analysis Approach}

Per the methodology described in Renewable Energy Assessment Methodology for Japanese OCONUS Installations (Solana et al. 2010), GSHPs were evaluated using the data from the 2009 Facility Energy Decision System (FEDS) assessment for the Kanto installations (Kora and Brown 2010). The FEDS building energy model was used to develop a representation of the Kanto installations based upon the 2009 PNNL data-gathering trip. Building data were entered for groups of similar buildings based on age, size, and use type. Table E.1 shows the general characteristics of buildings in each group and Table E.2 shows which buildings are in each group (groups in which no buildings were found to be economic candidates for GSHPs have been left out of Table E.2 for brevity). Open-loop, horizontal closed-loop, and vertical closed-loop configurations were analyzed for all buildings.

The 2009 FEDS model was updated with current fuel, equipment, and labor prices, and fuel use information to determine cost-effectiveness for GSHPs across the sites. Site-specific typical meteorological year (TMY) weather data for Tokyo-Hyakuri and the following soil/ground characteristics were used in the calculations. Though these characteristics are sufficient to generate preliminary project recommendations, detailed soil testing of a specific site is necessary before actual project costs can be determined.

- Soil thermal diffusivity: $0.02 \mathrm{ft}^{2} / \mathrm{hr}$

- Overburden depth: $100 \mathrm{ft}$

- Bedrock thermal conductivity: $1.4 \mathrm{Btu} /\left(\mathrm{hr} \cdot \mathrm{ft} \cdot{ }^{\circ} \mathrm{F}\right)$

The model does not consider site limitations like land area or water source availability (for closed and open loops, respectively). The assumption is that there are sufficient thermal sources/sinks in place. However, it should be noted that some of the Kanto installations have space restrictions that may prevent the installation of GSHPs. 
Table E.1: Building Groups Analyzed in FEDS for GSHPs

\begin{tabular}{|c|c|c|c|c|}
\hline \multirow[b]{2}{*}{$\begin{array}{c}\text { Group } \\
\text { ID }\end{array}$} & \multicolumn{4}{|c|}{ "Building Group Description } \\
\hline & Description & $\begin{array}{c}\text { Average Size } \\
\text { (sf) }\end{array}$ & $\begin{array}{l}\text { Average } \\
\text { Vintage }\end{array}$ & $\begin{array}{c}\text { Number of } \\
\text { Buildings } \\
\text { Represented }\end{array}$ \\
\hline \multicolumn{5}{|c|}{ Akasaka Press Center (PC) } \\
\hline $10 \mathrm{i}$ & Access Control Facilities & 116 & 2004 & 2 \\
\hline 30b-3 & Hardy Barracks & 57892 & 1964 & 1 \\
\hline $50 \mathrm{a}$ & Stars and Stripes Building & 97,383 & 1962 & 1 \\
\hline \multicolumn{5}{|c|}{ Camp Zama } \\
\hline $10 \mathrm{a}$ & 1960s Medium School/Admin & 23,581 & 1953 & 3 \\
\hline $10 \mathrm{~b}$ & 1990s Large School/Admin & 35,264 & 1991 & 8 \\
\hline $10 \mathrm{c}$ & 1950s Small School/Admin & 4,413 & 1952 & 7 \\
\hline $10 \mathrm{~d}$ & 1980s Small School/Admin & 5,683 & 1986 & 9 \\
\hline $10 \mathrm{~g}$ & Large Admin & 139,607 & 1953 & 1 \\
\hline $10 \mathrm{~h}$ & Very Large Admin & 248,831 & 1953 & 1 \\
\hline $10 \mathrm{i}$ & Access Control Facilities & 59 & 1990 & 8 \\
\hline $21 \mathrm{a}$ & Medical Facilities & 9,225 & 1981 & 6 \\
\hline $23 a$ & Electronics/Sim Bldgs & 12,256 & 1989 & 6 \\
\hline 30b-1 & 1950s Medium Lodging/Barracks & 16,817 & 1955 & 12 \\
\hline 30b-2 & 1980s Large Lodging/Barracks & 30,581 & 1989 & 6 \\
\hline 30sf-1 & 1950s Family Housing Single Units & 3,686 & 1955 & 9 \\
\hline $30 s f-2$ & 1990s Family Housing Single Units & 2,199 & 1991 & 14 \\
\hline $30 \mathrm{sf}-4$ & 1990s Family Housing Triple Units & 5,042 & 1997 & 2 \\
\hline 30sf-6 & 1980s Family Housing Quad Units & 7,056 & 1983 & 21 \\
\hline $30 \mathrm{sf}-7$ & 1990s Family Housing Quad Units & 6,953 & 1995 & 21 \\
\hline 30 sf-8 & 2000s Family Housing Quad Units & 6,556 & 2004 & 1 \\
\hline 30 sf-9 & 2000s Family Housing 6-Units & 10,251 & 2002 & 5 \\
\hline $\begin{array}{c}\text { 30sf- } \\
10\end{array}$ & 2000s Family Housing Towers & 145,825 & 1996 & 2 \\
\hline $40 \mathrm{a}$ & Small unconditioned storage & 176 & 1995 & 3 \\
\hline $40 \mathrm{f}$ & 1960s Large Storage & 22932 & 1973 & 4 \\
\hline $40 \mathrm{~g}$ & 1950s Small Storage & 6,067 & 1950 & 3 \\
\hline $40 n$ & 1980s Large Storage & 21,823 & 1985 & 2 \\
\hline $40 \mathrm{o}$ & CEPs (Lighting only) & 4,776 & 1975 & 6 \\
\hline $50 \mathrm{c}$ & Medium Utility/Maintenance Buildings & 10,293 & 1989 & 8 \\
\hline $50 \mathrm{e}$ & Large Maintenance Buildings & 36,731 & 1990 & 2 \\
\hline $50 \mathrm{f}$ & Small Maintenance Bldgs & 568 & 1973 & 36 \\
\hline $60 \mathrm{a}$ & Exchange Facilities & 6,263 & 1954 & 6 \\
\hline $60 \mathrm{~b}$ & Emergency Bldgs & 4,207 & 1987 & 5 \\
\hline $60 \mathrm{c}$ & Dining Facilities/Commissary & 14,459 & 1991 & 5 \\
\hline $60 \mathrm{~d}$ & Post Exchange & 60,091 & 1988 & $\frac{1}{1}$ \\
\hline $80 \mathrm{a}$ & Miscellaneous & 10,536 & 1952 & 5 \\
\hline $80 \mathrm{~b}$ & MWR Facilities & 7,263 & 1989 & 18 \\
\hline $80 \mathrm{~d}$ & Fitness Center & 71,536 & 2001 & 1 \\
\hline \multicolumn{5}{|c|}{ Sagami Depot } \\
\hline 10a & 1950s Large Admin & 26,483 & 1950 & 1 \\
\hline $10 \mathrm{~b}$ & 2000s Large Admin & 25659 & 2000 & 1 \\
\hline 10c & 1950s Small Admin & 4,624 & 1954 & 2 \\
\hline $10 \mathrm{~d}$ & 1980s School/Admin & 2,260 & 1975 & 4 \\
\hline $10 \mathrm{i}$ & Access Control Facilities & 98 & 1993 & 7 \\
\hline $21 \mathrm{a}$ & Medical Facilities & 1,766 & 1956 & 3 \\
\hline $23 a$ & Electronics/Sim Bldgs & 2,682 & 1995 & 2 \\
\hline
\end{tabular}


Table E.1: Building Groups Analyzed in FEDS for GSHPs

\begin{tabular}{|c|c|c|c|c|}
\hline \multirow[b]{2}{*}{$\begin{array}{c}\text { Group } \\
\text { ID }\end{array}$} & \multicolumn{4}{|c|}{ Building Group Description } \\
\hline & Description & $\begin{array}{c}\text { Average Size } \\
\text { (sf) }\end{array}$ & $\begin{array}{c}\text { Average } \\
\text { Vintage }\end{array}$ & $\begin{array}{c}\text { Number of } \\
\text { Buildings } \\
\text { Represented }\end{array}$ \\
\hline 30 sf-1 & 1950s Family Housing Single Units & 1,739 & 1955 & 3 \\
\hline 30 sf-3 & 1950s Family Housing Duplex Units & 2,441 & 1957 & 13 \\
\hline 30 sf-4 & 1950s Family Housing Triple Units & 6,511 & 1959 & 2 \\
\hline 30 sf-5 & 1950s Family Housing Quad Units & 5,928 & 1956 & 13 \\
\hline $40 \mathrm{a}$ & Unconditioned Storage & 5,536 & 1992 & 23 \\
\hline $40 c$ & 1950s Large Storage & 195,518 & 1954 & 2 \\
\hline 40d & 1950s Very Large Storage & 339,666 & 1950 & 1 \\
\hline $40 \mathrm{e}$ & 1990s Medium Conditioned Warehouse & 53,089 & 1996 & 4 \\
\hline $40 \mathrm{f}$ & 1950s Small Warehouse & 7,107 & 1950 & 4 \\
\hline $40 \mathrm{~g}$ & 1950s Small Conditioned Warehouse & 9,000 & 1950 & 19 \\
\hline $40 \mathrm{i}$ & 1950s Medium Warehouse & 78,689 & 1954 & 6 \\
\hline $40 \mathrm{k}$ & 1990s Large Conditioned Storage & 81,185 & 1992 & 3 \\
\hline 401 & 2000s Very Large Storage & 111,262 & 2000 & 1 \\
\hline $40 \mathrm{~m}$ & 1990s Small Storage & 2,740 & 1983 & 4 \\
\hline $50 \mathrm{~b}$ & 1950s Medium Utility/Maintenance & 16,666 & 1951 & 3 \\
\hline $50 \mathrm{c}$ & 1990s Medium Utility/Maintenance & 5,068 & 1997 & 7 \\
\hline $50 \mathrm{~d}$ & 1950s Large Utility/Maintenance & 68,528 & 1950 & 2 \\
\hline $50 \mathrm{e}$ & 2000s Large Utility/Maintenance & 73,679 & 2000 & 2 \\
\hline $50 f$ & Small Utility/Maintenance & 545 & 1983 & 14 \\
\hline $60 \mathrm{a}$ & Exchange/Emergency Facilities & 6,639 & 1956 & 5 \\
\hline $60 \mathrm{~b}$ & Laundry Facility & 31785 & 1994 & 1 \\
\hline $80 a$ & Fitness Center & 11,831 & 1950 & 1 \\
\hline 80b & Separate Toilet/Showers/Changing Rooms & 993 & 1958 & 6 \\
\hline \multicolumn{5}{|c|}{ Sagamihara Family Housing Area (SFHA) } \\
\hline $10 \mathrm{c}$ & 1950s Small School/Admin & 5,489 & 1952 & 2 \\
\hline $10 \mathrm{~d}$ & 1980s School/Admin & 8614 & 1984 & 2 \\
\hline $10 \mathrm{f}$ & Large, New school & 104,972 & 2003 & 1 \\
\hline $10 \mathrm{i}$ & Access Control Facilities & 67 & 1995 & 4 \\
\hline $23 a$ & Electronics/Sim Bldgs & 2,989 & 1951 & 1 \\
\hline 30sf-1 & 1950s Family Housing Single Units & 1,668 & 1953 & 68 \\
\hline 30 sf-3 & 1950s Family Housing Duplex Units & 2,830 & 1955 & 32 \\
\hline 30 sf-4 & 1950s Family Housing Triple Units & 4,251 & 1951 & 26 \\
\hline 30 sf-5 & 1950s Family Housing Quad Units & 4,981 & 1951 & 20 \\
\hline 30 sf-7 & 1990s Family Housing Quad Units & 7,332 & 1991 & 14 \\
\hline 30sf-8 & 2000s Family Housing 6-Units & 6,662 & 2004 & 19 \\
\hline $40 \mathrm{~g}$ & 1950s Small Storage & 6,092 & 1953 & 1 \\
\hline $40 \mathrm{~m}$ & 1990s Small Storage & 653 & 1992 & 9 \\
\hline $40 n$ & 1970s Large Storage & 34,570 & 1976 & 1 \\
\hline $50 \mathrm{~b}$ & 1950s Utility/Maintenance & 6,177 & 1953 & 1 \\
\hline 50d & CEPs (Lighting only) & 7,797 & 1975 & 4 \\
\hline $60 \mathrm{a}$ & Exchange Facilities & 4,491 & 1953 & 1 \\
\hline $60 \mathrm{~b}$ & Emergency Facilities & 2,551 & 1991 & 2 \\
\hline $60 c$ & Commissary & 15,320 & 1984 & 2 \\
\hline $80 a$ & Miscellaneous & 4,113 & 1953 & 5 \\
\hline $80 \mathrm{~b}$ & Pool & 2,505 & 1955 & 1 \\
\hline \multicolumn{5}{|c|}{ Yokohama North Dock (ND) } \\
\hline $10 \mathrm{c}$ & 1950s Small Admin & 8,221 & 1946 & 2 \\
\hline 10d & 1980s School/Admin & 3672 & 1979 & 3 \\
\hline
\end{tabular}


Table E.1: Building Groups Analyzed in FEDS for GSHPs

\begin{tabular}{||c|l|c|c|c||}
\hline \multirow{2}{*}{$\begin{array}{c}\text { Group } \\
\text { ID }\end{array}$} & \multicolumn{1}{|c|}{ Building Group Description } & $\begin{array}{c}\text { Number of } \\
\text { Description }\end{array}$ & $\begin{array}{c}\text { Average Size } \\
\text { (sf) }\end{array}$ & $\begin{array}{c}\text { Average } \\
\text { Buildings } \\
\text { Vepresented }\end{array}$ \\
\hline \hline 10e & Large Admin & 63,787 & 1955 & 1 \\
\hline 10i & Access Control Facilities & 92 & 1983 & 4 \\
\hline 23a & Electronics/Sim Bldgs & 3,642 & 2006 & 1 \\
\hline 40a & 1980s Small Storage & 1,293 & 1996 & 4 \\
\hline 40g & 1950s Medium Storage & 4,963 & 1955 & 5 \\
\hline 40h & 1940s Large Storage & 49,677 & 1945 & 1 \\
\hline 40n & 1970s Large Storage & 42,266 & 1974 & 1 \\
\hline 50b & 1950s Utility/Maintenance & 6,355 & 1970 & 6 \\
\hline 50c & 2000s Utility/Maintenance & 6,528 & 2005 & 2 \\
\hline 50d & Large Maintenance & 34,527 & 1945 & 1 \\
\hline 50f & 1970s Small Utility/Maintenance & 449 & 1979 & 11 \\
\hline 60a & Exchange/Emergency Facilities & 5,827 & 1952 & 3 \\
\hline 80c & Fitness/Changing Rooms & 3,112 & 1968 & 5 \\
\hline
\end{tabular}


Table E.2: Buildings Analyzed in FEDS for GSHPs*

\begin{tabular}{|c|c|c|c|}
\hline Installation & Description & $\begin{array}{l}\text { Group } \\
\text { ID }\end{array}$ & Building Numbers \\
\hline Akasaka PC & Hardy Barracks & $30 b-3$ & 1 \\
\hline Camp Zama & 1990s Large School/Admin & $10 \mathrm{~b}$ & 919, 906, 642, 278, 250, 123, 103, 913 \\
\hline Camp Zama & Medical Facilities & $21 \mathrm{a}$ & $1044,1042,721,704,681,110$ \\
\hline Camp Zama & Electronics/Sim Bldgs & $23 a$ & $1038,771,715,696,125,121$ \\
\hline Camp Zama & $\begin{array}{l}\text { 1950s Medium } \\
\text { Lodging/Barracks }\end{array}$ & 30b-1 & $\begin{array}{c}\text { 793, 782, 781, 780, 763, 762, 761, 760, } \\
\text { 581, 563, 551, 550 }\end{array}$ \\
\hline Camp Zama & 1980s Large Lodging/Barracks & $30 \mathrm{~b}-2$ & $795,742,585,552,341,332$ \\
\hline Camp Zama & $\begin{array}{l}\text { 1990s Family Housing Single } \\
\text { Units }\end{array}$ & 30 sf-2 & $\begin{array}{c}1036,1012,1011,1010,880,879,878 \\
877,876,875,874,873,872,871\end{array}$ \\
\hline Camp Zama & 2000s Family Housing Towers & 30 sf-10 & 743,1050 \\
\hline Camp Zama & 1960s Large Storage (offices) & $40 \mathrm{f}$ & $685,671,625,253$ \\
\hline Camp Zama & Emergency Buildings & $60 \mathrm{~b}$ & $1018,238,235,229,228$ \\
\hline Camp Zama & Dining Facilities/Commissary & $60 c$ & $851,690,457,450,333$ \\
\hline Camp Zama & Post Exchange & $60 d$ & 425 \\
\hline Camp Zama & MWR Facilities & $80 b$ & $\begin{array}{c}915,314,10423,10421,1045,1030, \\
1027,812,808,807,806,803,802,801, \\
719,389,381,267\end{array}$ \\
\hline Sagami Depot & 1980s School/Admin & $10 \mathrm{~d}$ & $14523,1053,1052,1049$ \\
\hline Sagami Depot & $\begin{array}{l}\text { 1990s Medium Conditioned } \\
\text { Warehouse }\end{array}$ & $40 \mathrm{e}$ & 1862, 1861, 1163, 1061 \\
\hline Sagami Depot & $\begin{array}{l}\text { 1950s Small Conditioned } \\
\text { Warehouse }\end{array}$ & $40 g$ & $\begin{array}{c}\text { 17210, 1742, 1736, 1735, 1732, 1729, } \\
\text { 1727, 1718, 1646, 1541, 1514, 1502, } \\
\text { 1431, 1351, 1342, 1341, 1323, 1312, } \\
1308\end{array}$ \\
\hline Sagami Depot & Exchange/Emergency Facilities & $60 a$ & $10317,1435,8011,1352,1303$ \\
\hline SFHA & 1980s School/Admin & $10 \mathrm{~d}$ & 337,107 \\
\hline SFHA & Large, New school & $10 \mathrm{f}$ & 12201 \\
\hline SFHA & Access Control Facilities & $10 \mathrm{i}$ & 12204, 11001, 254, 99 \\
\hline SFHA & $\begin{array}{l}\text { 1950s Family Housing Triple } \\
\text { Units }\end{array}$ & 30 sf-4 & $\begin{array}{c}\text { 624, 621, 620, 617, 600, 451, 434, 426, } \\
\text { 422, 362, 358, 350, 344, 247, 243, 241, } \\
\text { 237, 236, 230, 222, 218, 214, 201, 155, } \\
\text { 149, } 145\end{array}$ \\
\hline SFHA & $\begin{array}{l}\text { 1950s Family Housing Quad } \\
\text { Units }\end{array}$ & 30 sf-5 & $\begin{array}{c}\text { 627, 622, 619, 608, 565, 557, 547, 452, } \\
\text { 424, 414, 411, 360, 348, 251, 249, 245, } \\
216,209,156,147\end{array}$ \\
\hline $\begin{array}{l}\text { Yokohama } \\
\text { ND }\end{array}$ & Access Control Facilities & $10 \mathrm{i}$ & $620,349,345,231$ \\
\hline $\begin{array}{l}\text { Yokohama } \\
\text { ND }\end{array}$ & Exchange/Emergency Facilities & $60 a$ & 437, 331, 219 \\
\hline
\end{tabular}

* Building groups with no economically feasible projects are not included in this list

\section{Ground Source Heat Pump Resource Characterization}

GSHP assessments using FEDS have been completed at many sites in the past using the same analytic approach. The results developed here agree with previous findings. In general, conditions favoring replacement of existing heating and cooling systems with GSHPs include:

- Replacing old equipment. Equipment at the end of its useful life that will soon be replaced provides further economic incentive for GSHP installations, particularly if existing ductwork can be reused. 
- More extreme climates. Cold winters, hot summers, or large daily temperature swings allow GSHPs to operate more efficiently than other electric cooling and heating systems. The cost of heating operation is comparable to non-electric heating systems.

- High cost of non-electric fuels. If electricity is less than approximately 3.5 times as expensive per Btu than other fuels, GSHPs will generally be cost-effective. If no other fuel option is available and electric costs are high, GSHPs will be less expensive to operate than air-source heat pumps.

GSHPs are often not cost-effective in a building that:

- Does not have both cooling and heating. A building needs to be heated and cooled to take advantage of the GSHP efficiency in both modes. However, most of the savings are realized in the heating mode, so buildings with no cooling can still benefit from GSHPs.

- Does not currently have ductwork. Installing a new air distribution system in addition to the conditioning equipment generally adds too much cost for a GSHP retrofit, unless the building is modified to allow zone level heat pumps to be used in conjunction with a water loop connecting the terminal units to a shared ground loop.

- Is newer. Newer buildings (less than about 4 years old) generally have fairly efficient equipment (or at least the performance has not yet degraded significantly). As a result, premature replacement with a GSHP is generally uneconomic. In addition, the building envelope tends to be better, lengthening payback duration.

- Is located in a mild climate. An air-source heat pump has many of the benefits of a GSHP except in extreme temperature conditions. These extreme temperature conditions often are not sufficient to justify replacement.

- Uses an air-source heat pump. An air-source heat pump has many of the benefits of a GSHP except in extreme temperature conditions. These extreme temperature conditions often are not enough to justify replacement.

- Is connected to a central energy plant (unless the CEP will be abandoned). Although central energy systems are often consider to be large energy wasters, on a building-bybuilding basis (that does not account for distribution losses), it is difficult to justify replacement. Centralized chiller plants can use larger, more efficient water-cooled units and can stage several chillers to run closer to full load (which is the most efficient mode).

\section{Ground Source Heat Pumps: Economic and Other Analysis Parameters}

FEDS allows two primary financing options: appropriated funding (using Energy Conservation Investment Program, or ECIP, funds) and alternative financing (Utility Energy Services Contract (UESC) or Energy Saving Performance Contract (ESPC)). The parameters for alternative financing can be adjusted to match the options available to the site. For this assessment, a project life of 25 years and a third-party interest rate of $5 \%$ were used. For both appropriated 
funding and alternative financing scenarios, a global cost multiplier of 1.3 was used to account for differences between U.S. pricing (which the model is based on) and Japanese pricing.

FEDS uses the site electric rate schedule and energy costs to determine fuel costs and savings for GSHP retrofits. The rate schedule is entered into the modeling software so that consumption and demand can be calculated on a time-of-use basis. The electric costs for the Kanto installations are characterized according to the following rate schedule. While the actual rate schedule differs for each installation, they are relatively similar and can be sufficiently represented by Camp Zama’s schedule:

\section{$\underline{\text { Winter }}$}

$\checkmark$ Weekdays and Saturday

o 2200 to 0800 : $¥ 7.98 / \mathrm{kWh}$

o 0800 to 2200 : $¥ 11.08 / \mathrm{kWh}$

$\checkmark$ Sunday

o $¥ 7.98 / \mathrm{kWh}$

$\underline{\text { Summer }}$

$\checkmark$ Weekdays and Saturday

o 2200 to 800 : $¥ 7.98 / \mathrm{kWh}$

o 800 to 1300 : $¥ 12.13 / \mathrm{kWh}$

o 1300 to 1600 : $¥ 12.68 / \mathrm{kWh}$

o 1600 to 2200 : $¥ 12.13 / \mathrm{kWh}$

$\checkmark$ Sunday

o $¥ 7.98 / \mathrm{kWh}$

In addition, there is a demand charge of $¥ 1,395 / \mathrm{kW}$ at all times. A fuel oil cost of $¥ 209 /$ gallon (¥1,506/MMBtu) and a natural gas cost of $¥ 164$.3/therm (¥1,643/MMBtu) were used for this analysis, based on Army Energy and Water Reporting System (AEWRS) data.

The average GSHP system costs per square foot for the analysis seen in Table E.3 are as follows

- Open loop: $¥ 364 / \mathrm{ft}^{2}$

- Horizontal closed-loop: $¥ 641 / \mathrm{ft}^{2}$

- Vertical closed-loop: $¥ 678 / \mathrm{ft}^{2}$

Note that these costs should be used only as a rough reference for the buildings modeled in this analysis because heating and cooling loads (on a per square foot basis) can vary drastically between buildings.

\section{Findings: Ground Source Heat Pumps}

GSHPs were found to be economic in some situations for all five Kanto installations. Open-loop GSHPs tend to be the most cost-effective because of their low capital cost, but closed-loop GSHPs were also found to be economic for certain building types. 
These findings are driven predominantly by the high cost of fossil fuels. The Kanto installations do not have an ideal climate for GSHPs because of the dominant heating season, but the imbalance between heating and cooling loads could be mitigated by selecting large buildings with high internal heat gains.

GSHPs have a distinct advantage over other renewable energy sources at the Kanto installations. Because GSHPs are a retrofit technology, they would be funded through IMCOM, rather than through Japanese funding sources. This improves the chances of receiving funding, especially through appropriated sources like the Energy Conservation Investment Program (ECIP).

The simple payback values presented in Table E.3 are the average for all buildings with economic projects within that group. Some of the building groups in Table E. 3 contain buildings served by different fuels or with other noteworthy differences. To find the economic characteristics for buildings with specific heating and cooling technologies within a group, see appendix E-1, which contains the economic results for each building examined. 
Table E.3: Simple Payback Period for Building Groups Analyzed in FEDS for GSHPs ${ }^{1}$

\begin{tabular}{|c|c|c|c|c|c|c|c|c|}
\hline \multirow[b]{2}{*}{ Installation } & \multirow[b]{2}{*}{ Description } & \multirow{2}{*}{$\begin{array}{c}\text { Group } \\
\text { ID }\end{array}$} & \multicolumn{3}{|c|}{ Alternative Financing } & \multicolumn{3}{|c|}{ Appropriated Funding } \\
\hline & & & Open $^{2}$ & Horz $^{3}$ & Vert $^{4}$ & Open & Horz & Vert \\
\hline Akasaka PC & Hardy Barracks & 30b-3 & $\overline{5.8}$ & 12.9 & 11.6 & 4.6 & 9.4 & 9.1 \\
\hline Camp Zama & $\begin{array}{l}\text { 1990s Large } \\
\text { School/Admin }\end{array}$ & 10b & 25.8 & - & - & 16.6 & - & - \\
\hline Camp Zama & Medical Facilities & $21 \mathrm{a}$ & - & - & - & 7.1 & - & - \\
\hline Camp Zama & Electronics/Sim Bldgs & $23 a$ & 7.1 & - & - & 6.0 & - & - \\
\hline Camp Zama & \begin{tabular}{|l} 
1950s Medium \\
Lodging/Barracks
\end{tabular} & 30b-1 & - & - & - & 10.1 & - & - \\
\hline Camp Zama & $\begin{array}{l}\text { 1980s Large } \\
\text { Lodging/Barracks }\end{array}$ & 30b-2 & 6.1 & 15.5 & 15.6 & 5.4 & 13.4 & 13.6 \\
\hline Camp Zama & $\begin{array}{l}\text { 1990s Family Housing } \\
\text { Single Units }\end{array}$ & 30sf-2 & - & 15.8 & 17.2 & - & 14.0 & 14.9 \\
\hline Camp Zama & $\begin{array}{l}\text { 2000s Family Housing } \\
\text { Towers }\end{array}$ & 30sf-10 & 23.3 & - & - & 16.2 & - & - \\
\hline Camp Zama & \begin{tabular}{|l} 
1960s Large Storage \\
(offices)
\end{tabular} & $40 \mathrm{f}$ & - & - & - & - & 16.7 & 15.3 \\
\hline Camp Zama & Emergency Buildings & $60 \mathrm{~b}$ & - & - & - & 8.1 & 14.8 & - \\
\hline Camp Zama & \begin{tabular}{|l|} 
Dining \\
Facilities/Commissary
\end{tabular} & $60 c$ & 7.4 & - & - & 6.1 & - & - \\
\hline Camp Zama & Post Exchange & $60 \mathrm{~d}$ & - & - & - & 7.6 & - & - \\
\hline Camp Zama & MWR Facilities & $80 \mathrm{~b}$ & - & - & - & - & 13.9 & 14.5 \\
\hline Sagami Depot & 1980s School/Admin & $10 \mathrm{~d}$ & - & - & 8.2 & - & 7.6 & 7.5 \\
\hline Sagami Depot & $\begin{array}{l}\text { 1990s Medium } \\
\text { Conditioned Warehouse }\end{array}$ & $40 \mathrm{e}$ & 5.2 & 11.0 & 7.0 & 4.6 & 11.3 & 5.4 \\
\hline Sagami Depot & $\begin{array}{l}\text { 1950s Small Conditioned } \\
\text { Warehouse }\end{array}$ & $40 \mathrm{~g}$ & 6.7 & - & 5.1 & 6.4 & 5.6 & 4.8 \\
\hline Sagami Depot & \begin{tabular}{|l} 
Exchange/Emergency \\
Facilities
\end{tabular} & $60 \mathrm{a}$ & 7.7 & - & - & 6.8 & - & - \\
\hline SFHA & 1980s School/Admin & $10 \mathrm{~d}$ & - & - & - & 21.2 & - & - \\
\hline SFHA & Large, New school & $10 \mathrm{f}$ & - & - & - & 5.5 & - & - \\
\hline SFHA & Access Control Facilities & $10 \mathrm{i}$ & - & - & - & - & 8.4 & 9.7 \\
\hline SFHA & $\begin{array}{l}\text { 1950s Family Housing } \\
\text { Triple Units }\end{array}$ & 30sf-4 & - & - & - & 7.5 & - & - \\
\hline SFHA & $\begin{array}{l}\text { 1950s Family Housing } \\
\text { Quad Units }\end{array}$ & 30sf-5 & - & - & - & 6.9 & - & - \\
\hline Yokohama ND & Access Control Facilities & $10 \mathrm{i}$ & - & 7.0 & 9.1 & - & 6.4 & 8.4 \\
\hline Yokohama ND & $\begin{array}{l}\text { Exchange/Emergency } \\
\text { Facilities }\end{array}$ & $60 \mathrm{a}$ & 8.0 & - & 10.5 & 7.0 & 13.7 & 9.2 \\
\hline
\end{tabular}

In addition to energy and cost savings, GSHP systems generally reduce greenhouse gas emissions. The potential annual $\mathrm{CO}_{2}$ reductions from cost-effective GSHP projects are presented in Table E.4. The $\mathrm{CO}_{2}$ reductions are presented for open-loop, horizontal closed-loop, and vertical closed-loop systems because the energy and emissions savings vary depending on the type of system installed. The potential $\mathrm{CO}_{2}$ reduction for each project is based on the fossil fuel reduction, the change in electricity consumption, and the associated emissions factors. FEDS contains a feature that allows the user to override the assumed amount of greenhouse gases per unit of fuel, if a more exact value is known. In this case, the amount of $\mathrm{CO}_{2}$ generated by 
electricity production in Japan differs from that of electricity in the United States, so a more location-specific value of $0.444 \mathrm{~kg}-\mathrm{CO}_{2} / \mathrm{kWh}$ was used (FEPC 2009).

Table E.4: Total $\mathrm{CO}_{2}$ Reductions for GSHP Retrofits (tons $\mathrm{CO}_{2}$ per year)*

\begin{tabular}{|c|c|c|c|c|c|}
\hline Installation & Description & $\begin{array}{l}\text { Group } \\
\text { ID } \\
\end{array}$ & Open & Horz & Vert \\
\hline Akasaka PC & Hardy Barracks & $30 \mathrm{~b}-3$ & 55 & 54 & 59 \\
\hline Camp Zama & 1990s Large School/Admin & 10b & 166 & - & - \\
\hline Camp Zama & Medical Facilities & $21 \mathrm{a}$ & 52 & - & - \\
\hline Camp Zama & Electronics/Sim Bldgs & $23 a$ & 93 & - & - \\
\hline Camp Zama & 1950s Medium Lodging/Barracks & 30b-1 & 46 & - & - \\
\hline Camp Zama & 1980s Large Lodging/Barracks & $30 \mathrm{~b}-2$ & 947 & 935 & 948 \\
\hline Camp Zama & 1990s Family Housing Single Units & 30 sf-2 & - & 4 & 4 \\
\hline Camp Zama & 2000s Family Housing Towers & 30sf-10 & 604 & - & - \\
\hline Camp Zama & 1960s Large Storage (offices) & $40 \mathrm{f}$ & - & 3 & 3 \\
\hline Camp Zama & Emergency Buildings & $60 \mathrm{~b}$ & 37 & 32 & - \\
\hline Camp Zama & Dining Facilities/Commissary & $60 c$ & 110 & - & - \\
\hline Camp Zama & Post Exchange & $60 d$ & 24 & - & - \\
\hline Camp Zama & MWR Facilities & $80 \mathrm{~b}$ & - & 69 & 71 \\
\hline Sagami Depot & 1980s School/Admin & $10 \mathrm{~d}$ & - & 4 & 5 \\
\hline Sagami Depot & $\begin{array}{l}\text { 1990s Medium Conditioned } \\
\text { Warehouse }\end{array}$ & $40 \mathrm{e}$ & 123 & 96 & 105 \\
\hline Sagami Depot & $\begin{array}{l}\text { 1950s Small Conditioned } \\
\text { Warehouse }\end{array}$ & $40 \mathrm{~g}$ & 36 & 31 & 31 \\
\hline Sagami Depot & Exchange/Emergency Facilities & $60 \mathrm{a}$ & 58 & - & - \\
\hline SFHA & 1980s School/Admin & $10 \mathrm{~d}$ & 2 & - & - \\
\hline SFHA & Large, New school & $10 \mathrm{f}$ & -7 & - & - \\
\hline SFHA & Access Control Facilities & $10 \mathrm{i}$ & - & 0 & 0 \\
\hline SFHA & 1950s Family Housing Triple Units & 30 sf-4 & 7 & - & - \\
\hline SFHA & 1950s Family Housing Quad Units & 30 sf-5 & 17 & - & - \\
\hline Yokohama ND & Access Control Facilities & $10 \mathrm{i}$ & - & 6 & 7 \\
\hline Yokohama ND & Exchange/Emergency Facilities & $60 \mathrm{a}$ & 11 & 8 & 10 \\
\hline
\end{tabular}

* Building groups with no economically feasible projects are not included in this list

It is unlikely that GSHP projects at the Akasaka PC, Sagami General Depot, SFHA, and Yokohama ND will be implemented because of space limitations and/or mission conflicts. Camp Zama, on the other hand, is likely to find a number of promising options for GSHPs.

\section{Ground Source Heat Pumps: Next Steps}

The implementation of renewable energy sources at the Kanto installations is challenging because, among other issues, funding sources are difficult to obtain. GSHPs are unique in that they are a retrofit technology. As such, the Kanto installations can apply for funding through the ECIP program or other IMCOM appropriated funding sources. This analysis indicates that GSHP retrofits with appropriated funding would be cost-effective for various buildings, and should be pursued.

The next step will be to choose individual buildings appropriate for retrofit based on the results listed in Appendix E-1 and on land availability for heat exchange wells and/or piping. Once specific buildings have been identified, a project can be assembled and submitted for funding. 
When funding is obtained, experienced designers can be involved to gather further site-specific data and specify a project.

In addition to pursuing retrofit projects recommended here, the Kanto installations should analyze new construction projects, buildings with failed heating and/or cooling equipment, and major renovations to determine if additional opportunities for GSHPs exist. New incentives or changes in energy costs may result in additional cost-effective projects as well.

\section{Ground Source Heat Pump Sources of Information}

Federal Technology Alert. "Ground Source Heat Pumps Applied to Federal Facilities - Second Edition.” Federal Energy Management Program. DOE/EE-0245. March 2001. http://www1.eere.energy.gov/femp/pdfs/FTA_gshp.pdf.

FEPC-The Federation of Electric Power Companies of Japan. 2009. Environmental Action Plan by the Japanese Electric Utility Industry. September 2009. Accessed May 2010 at http://www.fepc.or.jp/english/library/environmental_action_plan/index.html.

Kora, AR and DR Brown. 2010. Facility Energy Decision System (FEDS) Assessment Report for U.S. Army Garrison, Japan - Honshu Installations. Pacific Northwest National Laboratory, Richland, Washington. PNNL-19232. March 2010.

Solana, AE, WJ Gorrissen, JR Hand, JA Horner, AR Kora, AC Orrell, BJ Russo, MR Weimar, and JL Williamson. 2010. Renewable Energy Assessment Methodology for Japanese OCONUS Army Installations. Pacific Northwest National Laboratory, Richland, Washington. 


\section{Appendix E.1: Detailed GSHP Economic Results}

Appendix E.1 presents the estimated simple payback period, savings to investment ratio, installed capital cost, and savings for each GSHP project that was found to be cost-effective. The economic results vary based on the type of building, current heating and cooling technologies, and the funding source.

\begin{tabular}{|c|c|c|c|c|c|c|c|c|c|c|}
\hline Installation & $\begin{array}{l}\text { Funding } \\
\text { Source }\end{array}$ & Description & $\begin{array}{l}\text { Group } \\
\text { ID }\end{array}$ & $\begin{array}{c}\text { Current } \\
\text { Heating/Cooling } \\
\text { Technology }\end{array}$ & $\begin{array}{c}\text { Retrofit } \\
\text { Technology }\end{array}$ & $\begin{array}{c}\text { Payback } \\
\text { Period } \\
\text { (years) }\end{array}$ & $\begin{array}{l}\text { Savings to } \\
\text { Investment } \\
\text { Ratio }\end{array}$ & $\begin{array}{c}\text { Installed } \\
\text { Capital Cost } \\
(¥)\end{array}$ & $\begin{array}{c}\text { Energy } \\
\text { Savings } \\
\text { (MMBtu/yr) }\end{array}$ & $\begin{array}{c}\text { Cost } \\
\text { Savings } \\
\text { (¥/yr) }\end{array}$ \\
\hline $\begin{array}{c}\text { Akasaka } \\
\text { Press Center }\end{array}$ & Alternative & Hardy Barracks & 30b-3 & $\begin{array}{c}\text { Distillate Oil } \\
\text { Conventional } \\
\text { Boiler/Electric } \\
\text { Package Unit } \\
\end{array}$ & $\begin{array}{c}\text { Horizontal } \\
\text { Closed-Loop } \\
\text { GSHP }\end{array}$ & 13.2 & 1.4 & $¥ 18,325,800$ & 744 & $¥ 1,388,300$ \\
\hline $\begin{array}{c}\text { Akasaka } \\
\text { Press Center }\end{array}$ & Appropriated & Hardy Barracks & $30 b-3$ & $\begin{array}{c}\text { Distillate Oil } \\
\text { Conventional } \\
\text { Boiler/Electric } \\
\text { Package Unit } \\
\end{array}$ & $\begin{array}{c}\text { Horizontal } \\
\text { Closed-Loop } \\
\text { GSHP }\end{array}$ & 9.6 & 2.1 & $¥ 18,325,800$ & 744 & $¥ 1,908,900$ \\
\hline $\begin{array}{c}\text { Akasaka } \\
\text { Press Center }\end{array}$ & Alternative & Hardy Barracks & $30 b-3$ & $\begin{array}{c}\text { Distillate Oil } \\
\text { Conventional } \\
\text { Boiler/Electric } \\
\text { Package Unit } \\
\end{array}$ & $\begin{array}{l}\text { Open-Loop } \\
\text { GSHP }\end{array}$ & 5.9 & 2.2 & $¥ 11,731,500$ & 749 & $¥ 1,988,400$ \\
\hline $\begin{array}{c}\text { Akasaka } \\
\text { Press Center }\end{array}$ & Appropriated & Hardy Barracks & $30 b-3$ & $\begin{array}{c}\text { Distillate Oil } \\
\text { Conventional } \\
\text { Boiler/Electric } \\
\text { Package Unit } \\
\end{array}$ & $\begin{array}{l}\text { Open-Loop } \\
\text { GSHP }\end{array}$ & 4.7 & 3.2 & $¥ 11,731,500$ & 749 & $¥ 2,496,100$ \\
\hline $\begin{array}{c}\text { Akasaka } \\
\text { Press Center }\end{array}$ & Alternative & Hardy Barracks & 30b-3 & $\begin{array}{c}\text { Distillate Oil } \\
\text { Conventional } \\
\text { Boiler/Electric } \\
\text { Package Unit } \\
\end{array}$ & $\begin{array}{c}\text { Vertical } \\
\text { Closed-Loop } \\
\text { GSHP }\end{array}$ & 11.8 & 1.4 & $¥ 22,680,200$ & 778 & $¥ 1,922,100$ \\
\hline $\begin{array}{c}\text { Akasaka } \\
\text { Press Center }\end{array}$ & Appropriated & Hardy Barracks & $30 b-3$ & $\begin{array}{c}\text { Distillate Oil } \\
\text { Conventional } \\
\text { Boiler/Electric } \\
\text { Package Unit } \\
\end{array}$ & $\begin{array}{c}\text { Vertical } \\
\text { Closed-Loop } \\
\text { GSHP }\end{array}$ & 9.3 & 2 & $¥ 22,680,200$ & 778 & $¥ 2,438,700$ \\
\hline Camp Zama & Alternative & $\begin{array}{c}\text { 1980s Large } \\
\text { Lodging/Barracks }\end{array}$ & $30 b-2$ & $\begin{array}{l}\text { Central Steam Air } \\
\text { Handling } \\
\text { Unit/Central Steam } \\
\text { Air-Cooled } \\
\text { Absorption Chiller }\end{array}$ & $\begin{array}{c}\text { Horizontal } \\
\text { Closed-Loop } \\
\text { GSHP }\end{array}$ & 15.5 & 2.1 & $¥ 30,582,000$ & 2,135 & $¥ 1,973,000$ \\
\hline
\end{tabular}




\begin{tabular}{|c|c|c|c|c|c|c|c|c|c|c|}
\hline Installation & $\begin{array}{l}\text { Funding } \\
\text { Source }\end{array}$ & Description & $\begin{array}{l}\text { Group } \\
\text { ID }\end{array}$ & $\begin{array}{c}\text { Current } \\
\text { Heating/Cooling } \\
\text { Technology }\end{array}$ & $\begin{array}{c}\text { Retrofit } \\
\text { Technology }\end{array}$ & $\begin{array}{c}\text { Payback } \\
\text { Period } \\
\text { (years) }\end{array}$ & $\begin{array}{c}\text { Savings to } \\
\text { Investment } \\
\text { Ratio }\end{array}$ & $\begin{array}{c}\text { Installed } \\
\text { Capital Cost } \\
\text { (¥) }\end{array}$ & $\begin{array}{c}\text { Energy } \\
\text { Savings } \\
\text { (MMBtu/yr) }\end{array}$ & $\begin{array}{l}\text { Cost } \\
\text { Savings } \\
\text { (¥/yr) }\end{array}$ \\
\hline Camp Zama & Alternative & $\begin{array}{c}\text { 1980s Large } \\
\text { Lodging/Barracks }\end{array}$ & $30 \mathrm{~b}-2$ & $\begin{array}{l}\text { Central Steam Air } \\
\text { Handling } \\
\text { Unit/Central Steam } \\
\text { Air-Cooled } \\
\text { Absorption Chiller }\end{array}$ & $\begin{array}{l}\text { Horizontal } \\
\text { Closed-Loop } \\
\text { GSHP }\end{array}$ & 15.4 & 2.1 & $¥ 43,520,500$ & 3,038 & $¥ 2,826,000$ \\
\hline Camp Zama & Appropriated & $\begin{array}{c}\text { 1980s Large } \\
\text { Lodging/Barracks }\end{array}$ & $30 \mathrm{~b}-2$ & $\begin{array}{l}\text { Central Steam Air } \\
\text { Handling } \\
\text { Unit/Central Steam } \\
\text { Air-Cooled } \\
\text { Absorption Chiller }\end{array}$ & $\begin{array}{l}\text { Horizontal } \\
\text { Closed-Loop } \\
\text { GSHP }\end{array}$ & 13.4 & 1.5 & $¥ 30,582,000$ & 2,135 & $¥ 2,282,200$ \\
\hline Camp Zama & Appropriated & $\begin{array}{l}\text { 1980s Large } \\
\text { Lodging/Barracks }\end{array}$ & $30 \mathrm{~b}-2$ & $\begin{array}{l}\text { Central Steam Air } \\
\text { Handling } \\
\text { Unit/Central Steam } \\
\text { Air-Cooled } \\
\text { Absorption Chiller }\end{array}$ & $\begin{array}{l}\text { Horizontal } \\
\text { Closed-Loop } \\
\text { GSHP }\end{array}$ & 13.4 & 1.5 & $¥ 43,520,500$ & 3,038 & $¥ 3,247,800$ \\
\hline Camp Zama & Alternative & $\begin{array}{l}\text { 1990s Family Housing } \\
\text { Single Units }\end{array}$ & $30 \mathrm{sf}-2$ & $\begin{array}{c}\text { Central Hot Water } \\
\text { Air Handling } \\
\text { Unit/Electric } \\
\text { Package Unit }\end{array}$ & $\begin{array}{l}\text { Horizontal } \\
\text { Closed-Loop } \\
\text { GSHP }\end{array}$ & 15.8 & 1.2 & $¥ 1,400,800$ & 31 & $¥ 88,700$ \\
\hline Camp Zama & Appropriated & $\begin{array}{c}\text { 1990s Family Housing } \\
\text { Single Units }\end{array}$ & 30sf-2 & $\begin{array}{c}\text { Central Hot Water } \\
\text { Air Handling } \\
\text { Unit/Electric } \\
\text { Package Unit } \\
\end{array}$ & $\begin{array}{l}\text { Horizontal } \\
\text { Closed-Loop } \\
\text { GSHP }\end{array}$ & 14 & 1.5 & $¥ 1,400,800$ & 31 & $¥ 100,100$ \\
\hline Camp Zama & Appropriated & Emergency Buildings & $60 \mathrm{~b}$ & $\begin{array}{l}\text { Central Steam Air } \\
\text { Handling } \\
\text { Unit/Electric Air- } \\
\text { Cooled Chiller }\end{array}$ & $\begin{array}{l}\text { Horizontal } \\
\text { Closed-Loop } \\
\text { GSHP }\end{array}$ & 14.8 & 1 & $¥ 31,293,300$ & 259 & $¥ 2,114,400$ \\
\hline Camp Zama & Appropriated & MWR Facilities & $80 \mathrm{~b}$ & $\begin{array}{c}\text { Central Steam Air } \\
\text { Handling } \\
\text { Unit/Electric Air- } \\
\text { Cooled Chiller } \\
\end{array}$ & $\begin{array}{l}\text { Horizontal } \\
\text { Closed-Loop } \\
\text { GSHP }\end{array}$ & 13.9 & 1.4 & $¥ 17,121,700$ & 240 & $¥ 1,231,800$ \\
\hline Camp Zama & Appropriated & MWR Facilities & $80 \mathrm{~b}$ & $\begin{array}{l}\text { Central Steam Air } \\
\text { Handling } \\
\text { Unit/Electric Air- } \\
\text { Cooled Chiller } \\
\end{array}$ & $\begin{array}{l}\text { Horizontal } \\
\text { Closed-Loop } \\
\text { GSHP }\end{array}$ & 13.9 & 1.4 & $¥ 26,752,700$ & 376 & $¥ 1,924,700$ \\
\hline Camp Zama & Appropriated & $\begin{array}{l}\text { 1960s Large Storage } \\
\text { (offices) }\end{array}$ & $40 f$ & $\begin{array}{c}\text { Central Steam Air } \\
\text { Handling } \\
\text { Unit/Electric } \\
\text { Package Unit }\end{array}$ & $\begin{array}{l}\text { Horizontal } \\
\text { Closed-Loop } \\
\text { GSHP }\end{array}$ & 16.7 & 1.3 & $¥ 2,391,500$ & 28 & $¥ 143,200$ \\
\hline
\end{tabular}




\begin{tabular}{|c|c|c|c|c|c|c|c|c|c|c|}
\hline Installation & $\begin{array}{l}\text { Funding } \\
\text { Source }\end{array}$ & Description & $\begin{array}{l}\text { Group } \\
\text { ID }\end{array}$ & $\begin{array}{c}\text { Current } \\
\text { Heating/Cooling } \\
\text { Technology }\end{array}$ & $\begin{array}{c}\text { Retrofit } \\
\text { Technology }\end{array}$ & $\begin{array}{c}\text { Payback } \\
\text { Period } \\
\text { (years) }\end{array}$ & $\begin{array}{c}\text { Savings to } \\
\text { Investment } \\
\text { Ratio }\end{array}$ & $\begin{array}{c}\text { Installed } \\
\text { Capital Cost } \\
\text { (¥) }\end{array}$ & $\begin{array}{c}\text { Energy } \\
\text { Savings } \\
\text { (MMBtu/yr) }\end{array}$ & $\begin{array}{l}\text { Cost } \\
\text { Savings } \\
\text { (¥/yr) }\end{array}$ \\
\hline Camp Zama & Appropriated & $\begin{array}{l}\text { 1950s Medium } \\
\text { Lodging/Barracks }\end{array}$ & 30b-1 & $\begin{array}{c}\text { Electric } \\
\text { Conventional } \\
\text { Furnace/Electric } \\
\text { Package Unit }\end{array}$ & $\begin{array}{l}\text { Open-Loop } \\
\text { GSHP }\end{array}$ & 10.1 & 1.1 & $¥ 12,375,000$ & 317 & $¥ 1,225,200$ \\
\hline Camp Zama & Alternative & $\begin{array}{c}\text { 1980s Large } \\
\text { Lodging/Barracks }\end{array}$ & $30 b-2$ & \begin{tabular}{|c|} 
Central Steam Air \\
Handling \\
Unit/Central Steam \\
Air-Cooled \\
Absorption Chiller \\
\end{tabular} & $\begin{array}{l}\text { Open-Loop } \\
\text { GSHP }\end{array}$ & 6.1 & 4 & $¥ 16,226,000$ & 2,158 & $¥ 2,660,000$ \\
\hline Camp Zama & Alternative & $\begin{array}{c}\text { 1980s Large } \\
\text { Lodging/Barracks }\end{array}$ & 30b-2 & \begin{tabular}{|c|} 
Central Steam Air \\
Handling \\
Unit/Central Steam \\
Air-Cooled \\
Absorption Chiller \\
\end{tabular} & $\begin{array}{l}\text { Open-Loop } \\
\text { GSHP }\end{array}$ & 6.1 & 4 & $¥ 23,090,900$ & 3,070 & $¥ 3,785,400$ \\
\hline Camp Zama & Appropriated & $\begin{array}{c}\text { 1980s Large } \\
\text { Lodging/Barracks }\end{array}$ & 30b-2 & \begin{tabular}{|c|} 
Central Steam Air \\
Handling \\
Unit/Central Steam \\
Air-Cooled \\
Absorption Chiller \\
\end{tabular} & $\begin{array}{l}\text { Open-Loop } \\
\text { GSHP }\end{array}$ & 5.4 & 3.1 & $¥ 16,226,000$ & 2,158 & $¥ 3,004,800$ \\
\hline Camp Zama & Appropriated & $\begin{array}{c}\text { 1980s Large } \\
\text { Lodging/Barracks }\end{array}$ & $30 \mathrm{~b}-2$ & \begin{tabular}{|c|} 
Central Steam Air \\
Handling \\
Unit/Central Steam \\
Air-Cooled \\
Absorption Chiller \\
\end{tabular} & $\begin{array}{l}\text { Open-Loop } \\
\text { GSHP }\end{array}$ & 5.4 & 3.1 & $¥ 23,090,900$ & 3,070 & $¥ 4,276,100$ \\
\hline Camp Zama & Alternative & 1990s Large School/Admin & $10 \mathrm{~b}$ & \begin{tabular}{|c|} 
Central Steam Air \\
Handling \\
Unit/Central Steam \\
Air-Cooled \\
Absorption Chiller \\
\end{tabular} & $\begin{array}{l}\text { Open-Loop } \\
\text { GSHP }\end{array}$ & 25.8 & 1.6 & $¥ 16,751,700$ & 1,436 & $¥ 649,300$ \\
\hline Camp Zama & Appropriated & 1990s Large School/Admin & $10 \mathrm{~b}$ & \begin{tabular}{|c|} 
Central Steam Air \\
Handling \\
Unit/Central Steam \\
Air-Cooled \\
Absorption Chiller \\
\end{tabular} & $\begin{array}{l}\text { Open-Loop } \\
\text { GSHP }\end{array}$ & 16.6 & 1.4 & $¥ 16,751,700$ & 1,436 & $¥ 1,009,100$ \\
\hline Camp Zama & Alternative & $\begin{array}{c}\text { 2000s Family Housing } \\
\text { Towers }\end{array}$ & 30 sf- 10 & \begin{tabular}{|c|} 
Central Steam Air \\
Handling \\
Unit/Central Steam \\
Water-Cooled \\
Absorption Chiller \\
\end{tabular} & $\begin{array}{l}\text { Open-Loop } \\
\text { GSHP }\end{array}$ & 23.3 & 1.9 & $¥ 30,947,600$ & 2,849 & $¥ 1,328,200$ \\
\hline
\end{tabular}




\begin{tabular}{|c|c|c|c|c|c|c|c|c|c|c|}
\hline Installation & $\begin{array}{l}\text { Funding } \\
\text { Source }\end{array}$ & Description & $\begin{array}{l}\text { Group } \\
\text { ID }\end{array}$ & $\begin{array}{c}\text { Current } \\
\text { Heating/Cooling } \\
\text { Technology }\end{array}$ & $\begin{array}{c}\text { Retrofit } \\
\text { Technology }\end{array}$ & $\begin{array}{c}\text { Payback } \\
\text { Period } \\
\text { (years) }\end{array}$ & $\begin{array}{c}\text { Savings to } \\
\text { Investment } \\
\text { Ratio }\end{array}$ & $\begin{array}{c}\text { Installed } \\
\text { Capital Cost } \\
\text { (¥) }\end{array}$ & $\begin{array}{c}\text { Energy } \\
\text { Savings } \\
\text { (MMBtu/yr) }\end{array}$ & $\begin{array}{l}\text { Cost } \\
\text { Savings } \\
\text { (¥/yr) }\end{array}$ \\
\hline Camp Zama & Alternative & $\begin{array}{c}\text { 2000s Family Housing } \\
\text { Towers }\end{array}$ & 30 sf-10 & $\begin{array}{l}\text { Central Steam Air } \\
\text { Handling } \\
\text { Unit/Central Steam } \\
\text { Water-Cooled } \\
\text { Absorption Chiller }\end{array}$ & $\begin{array}{l}\text { Open-Loop } \\
\text { GSHP }\end{array}$ & 23.3 & 1.9 & $¥ 29,734,000$ & 2,738 & $¥ 1,276,100$ \\
\hline Camp Zama & Appropriated & $\begin{array}{c}\text { 2000s Family Housing } \\
\text { Towers }\end{array}$ & 30 sf-10 & $\begin{array}{c}\text { Central Steam Air } \\
\text { Handling } \\
\text { Unit/Central Steam } \\
\text { Water-Cooled } \\
\text { Absorption Chiller }\end{array}$ & $\begin{array}{c}\text { Open-Loop } \\
\text { GSHP }\end{array}$ & 16.2 & 2.3 & $¥ 30,947,600$ & 2,849 & $¥ 1,910,300$ \\
\hline Camp Zama & Appropriated & $\begin{array}{c}\text { 2000s Family Housing } \\
\text { Towers }\end{array}$ & 30 sf-10 & $\begin{array}{l}\text { Central Steam Air } \\
\text { Handling } \\
\text { Unit/Central Steam } \\
\text { Water-Cooled } \\
\text { Absorption Chiller }\end{array}$ & $\begin{array}{l}\text { Open-Loop } \\
\text { GSHP }\end{array}$ & 16.2 & 2.3 & $¥ 29,734,000$ & 2,738 & $¥ 1,835,400$ \\
\hline Camp Zama & Alternative & $\begin{array}{c}\text { Dining } \\
\text { Facilities/Commissary }\end{array}$ & $60 c$ & $\begin{array}{l}\text { Central Steam Air } \\
\text { Handling } \\
\text { Unit/Electric Air- } \\
\text { Cooled Chiller }\end{array}$ & $\begin{array}{c}\text { Open-Loop } \\
\text { GSHP }\end{array}$ & 7.4 & 1.2 & $¥ 10,572,900$ & 153 & $¥ 1,428,800$ \\
\hline Camp Zama & Alternative & $\begin{array}{c}\text { Dining } \\
\text { Facilities/Commissary }\end{array}$ & 60c & $\begin{array}{l}\text { Central Steam Air } \\
\text { Handling } \\
\text { Unit/Electric Air- } \\
\text { Cooled Chiller } \\
\end{array}$ & $\begin{array}{l}\text { Open-Loop } \\
\text { GSHP }\end{array}$ & 7.5 & 1.2 & $¥ 37,005,200$ & 532 & $¥ 4,934,000$ \\
\hline Camp Zama & Alternative & $\begin{array}{c}\text { Dining } \\
\text { Facilities/Commissary }\end{array}$ & $60 c$ & $\begin{array}{l}\text { Central Steam Air } \\
\text { Handling } \\
\text { Unit/Electric Air- } \\
\text { Cooled Chiller }\end{array}$ & $\begin{array}{l}\text { Open-Loop } \\
\text { GSHP }\end{array}$ & 7.4 & 1.2 & $¥ 5,286,500$ & 77 & $¥ 714,400$ \\
\hline Camp Zama & Appropriated & $\begin{array}{c}\text { Dining } \\
\text { Facilities/Commissary }\end{array}$ & $60 c$ & $\begin{array}{c}\text { Central Steam Air } \\
\text { Handling } \\
\text { Unit/Electric Air- } \\
\text { Cooled Chiller } \\
\end{array}$ & $\begin{array}{l}\text { Open-Loop } \\
\text { GSHP }\end{array}$ & 6.3 & 1.8 & $¥ 10,572,900$ & 153 & $¥ 1,678,200$ \\
\hline Camp Zama & Appropriated & $\begin{array}{c}\text { Dining } \\
\text { Facilities/Commissary }\end{array}$ & $60 c$ & $\begin{array}{l}\text { Central Steam Air } \\
\text { Handling } \\
\text { Unit/Electric Air- } \\
\text { Cooled Chiller } \\
\end{array}$ & $\begin{array}{l}\text { Open-Loop } \\
\text { GSHP }\end{array}$ & 6 & 1.9 & $¥ 37,005,200$ & 532 & $¥ 6,167,500$ \\
\hline Camp Zama & Appropriated & $\begin{array}{c}\text { Dining } \\
\text { Facilities/Commissary }\end{array}$ & $60 c$ & $\begin{array}{l}\text { Central Steam Air } \\
\text { Handling } \\
\text { Unit/Electric Air- } \\
\text { Cooled Chiller }\end{array}$ & $\begin{array}{l}\text { Open-Loop } \\
\text { GSHP }\end{array}$ & 6.3 & 1.8 & $¥ 5,286,500$ & 77 & $¥ 839,100$ \\
\hline
\end{tabular}




\begin{tabular}{|c|c|c|c|c|c|c|c|c|c|c|}
\hline Installation & $\begin{array}{l}\text { Funding } \\
\text { Source }\end{array}$ & Description & $\begin{array}{l}\text { Group } \\
\text { ID }\end{array}$ & $\begin{array}{c}\text { Current } \\
\text { Heating/Cooling } \\
\text { Technology }\end{array}$ & $\begin{array}{c}\text { Retrofit } \\
\text { Technology }\end{array}$ & $\begin{array}{c}\text { Payback } \\
\text { Period } \\
\text { (years) }\end{array}$ & $\begin{array}{c}\text { Savings to } \\
\text { Investment } \\
\text { Ratio }\end{array}$ & $\begin{array}{c}\text { Installed } \\
\text { Capital Cost } \\
\text { (¥) }\end{array}$ & $\begin{array}{c}\text { Energy } \\
\text { Savings } \\
\text { (MMBtu/yr) }\end{array}$ & $\begin{array}{l}\text { Cost } \\
\text { Savings } \\
\text { (¥/yr) }\end{array}$ \\
\hline Camp Zama & Alternative & Electronics/Sim Bldgs & 23a & $\begin{array}{l}\text { Central Hot Water } \\
\text { Air Handling } \\
\text { Unit/Electric Air- } \\
\text { Cooled Chiller }\end{array}$ & $\begin{array}{l}\text { Open-Loop } \\
\text { GSHP }\end{array}$ & 7.1 & 1 & $¥ 6,594,500$ & 71 & $¥ 928,800$ \\
\hline Camp Zama & Alternative & Electronics/Sim Bldgs & $23 a$ & $\begin{array}{l}\text { Central Hot Water } \\
\text { Air Handling } \\
\text { Unit/Electric Air- } \\
\text { Cooled Chiller }\end{array}$ & $\begin{array}{l}\text { Open-Loop } \\
\text { GSHP }\end{array}$ & 7.1 & 1 & $¥ 14,987,600$ & 162 & $¥ 2,110,900$ \\
\hline Camp Zama & Appropriated & Electronics/Sim Bldgs & 23a & $\begin{array}{l}\text { Central Hot Water } \\
\text { Air Handling } \\
\text { Unit/Electric Air- } \\
\text { Cooled Chiller }\end{array}$ & $\begin{array}{c}\text { Open-Loop } \\
\text { GSHP }\end{array}$ & 6 & 1.8 & $¥ 6,594,500$ & 71 & $¥ 1,099,100$ \\
\hline Camp Zama & Appropriated & Electronics/Sim Bldgs & $23 a$ & $\begin{array}{l}\text { Central Hot Water } \\
\text { Air Handling } \\
\text { Unit/Electric Air- } \\
\text { Cooled Chiller }\end{array}$ & $\begin{array}{c}\text { Open-Loop } \\
\text { GSHP }\end{array}$ & 6 & 1.8 & $¥ 14,987,600$ & 162 & $¥ 2,497,900$ \\
\hline Camp Zama & Alternative & Electronics/Sim Bldgs & $23 a$ & $\begin{array}{l}\text { Central Steam Air } \\
\text { Handling } \\
\text { Unit/Electric Air- } \\
\text { Cooled Chiller }\end{array}$ & $\begin{array}{l}\text { Open-Loop } \\
\text { GSHP }\end{array}$ & 7.1 & 1 & $¥ 4,796,000$ & 52 & $¥ 675,500$ \\
\hline Camp Zama & Alternative & Electronics/Sim Bldgs & $23 a$ & $\begin{array}{l}\text { Central Steam Air } \\
\text { Handling } \\
\text { Unit/Electric Air- } \\
\text { Cooled Chiller }\end{array}$ & $\begin{array}{l}\text { Open-Loop } \\
\text { GSHP }\end{array}$ & 7.1 & 1 & $¥ 20,383,100$ & 220 & $¥ 2,870,900$ \\
\hline Camp Zama & Alternative & Electronics/Sim Bldgs & $23 a$ & $\begin{array}{l}\text { Central Steam Air } \\
\text { Handling } \\
\text { Unit/Electric Air- } \\
\text { Cooled Chiller }\end{array}$ & $\begin{array}{c}\text { Open-Loop } \\
\text { GSHP }\end{array}$ & 7.1 & 1 & $¥ 8,992,600$ & 97 & $¥ 1,266,600$ \\
\hline Camp Zama & Alternative & Electronics/Sim Bldgs & $23 a$ & $\begin{array}{l}\text { Central Steam Air } \\
\text { Handling } \\
\text { Unit/Electric Air- } \\
\text { Cooled Chiller }\end{array}$ & $\begin{array}{l}\text { Open-Loop } \\
\text { GSHP }\end{array}$ & 7.1 & 1 & $¥ 4,196,500$ & 45 & $¥ 591,100$ \\
\hline Camp Zama & Appropriated & Electronics/Sim Bldgs & $23 a$ & $\begin{array}{l}\text { Central Steam Air } \\
\text { Handling } \\
\text { Unit/Electric Air- } \\
\text { Cooled Chiller }\end{array}$ & $\begin{array}{c}\text { Open-Loop } \\
\text { GSHP }\end{array}$ & 6 & 1.8 & $¥ 4,796,000$ & 52 & $¥ 799,300$ \\
\hline Camp Zama & Appropriated & Electronics/Sim Bldgs & $23 a$ & $\begin{array}{l}\text { Central Steam Air } \\
\text { Handling } \\
\text { Unit/Electric Air- } \\
\text { Cooled Chiller } \\
\end{array}$ & $\begin{array}{c}\text { Open-Loop } \\
\text { GSHP }\end{array}$ & 6 & 1.8 & $¥ 20,383,100$ & 220 & $¥ 3,397,200$ \\
\hline
\end{tabular}




\begin{tabular}{|c|c|c|c|c|c|c|c|c|c|c|}
\hline Installation & $\begin{array}{l}\text { Funding } \\
\text { Source }\end{array}$ & Description & $\begin{array}{l}\text { Group } \\
\text { ID }\end{array}$ & $\begin{array}{c}\text { Current } \\
\text { Heating/Cooling } \\
\text { Technology }\end{array}$ & $\begin{array}{c}\text { Retrofit } \\
\text { Technology }\end{array}$ & $\begin{array}{c}\text { Payback } \\
\text { Period } \\
\text { (years) }\end{array}$ & $\begin{array}{c}\text { Savings to } \\
\text { Investment } \\
\text { Ratio }\end{array}$ & $\begin{array}{c}\text { Installed } \\
\text { Capital Cost } \\
\text { (¥) }\end{array}$ & $\begin{array}{c}\text { Energy } \\
\text { Savings } \\
\text { (MMBtu/yr) }\end{array}$ & $\begin{array}{c}\text { Cost } \\
\text { Savings } \\
\text { (¥/yr) }\end{array}$ \\
\hline Camp Zama & Appropriated & Electronics/Sim Bldgs & 23a & $\begin{array}{l}\text { Central Steam Air } \\
\text { Handling } \\
\text { Unit/Electric Air- } \\
\text { Cooled Chiller }\end{array}$ & $\begin{array}{c}\text { Open-Loop } \\
\text { GSHP }\end{array}$ & 6 & 1.8 & $¥ 8,992,600$ & 97 & $¥ 1,498,800$ \\
\hline Camp Zama & Appropriated & Electronics/Sim Bldgs & 23a & \begin{tabular}{|c|} 
Central Steam Air \\
Handling \\
Unit/Electric Air- \\
Cooled Chiller
\end{tabular} & $\begin{array}{l}\text { Open-Loop } \\
\text { GSHP }\end{array}$ & 6 & 1.8 & $¥ 4,196,500$ & 45 & $¥ 699,400$ \\
\hline Camp Zama & Appropriated & Emergency Buildings & $60 \mathrm{~b}$ & \begin{tabular}{|c} 
Central Steam Air \\
Handling \\
Unit/Electric Air- \\
Cooled Chiller
\end{tabular} & $\begin{array}{l}\text { Open-Loop } \\
\text { GSHP }\end{array}$ & 8.1 & 1.6 & $¥ 22,221,700$ & 293 & $¥ 2,743,400$ \\
\hline Camp Zama & Appropriated & Medical Facilities & $21 \mathrm{a}$ & \begin{tabular}{|c|} 
Central Hot Water \\
Air Handling \\
Unit/Electric Air- \\
Cooled Chiller \\
\end{tabular} & $\begin{array}{c}\text { Open-Loop } \\
\text { GSHP }\end{array}$ & 7.4 & 1.5 & $¥ 2,655,400$ & 21 & $¥ 358,800$ \\
\hline Camp Zama & Appropriated & Medical Facilities & $21 \mathrm{a}$ & \begin{tabular}{|c} 
Central Steam Air \\
Handling \\
Unit/Electric Air- \\
Cooled Chiller
\end{tabular} & $\begin{array}{l}\text { Open-Loop } \\
\text { GSHP }\end{array}$ & 7 & 1.6 & $¥ 36,644,600$ & 290 & $¥ 5,234,900$ \\
\hline Camp Zama & Appropriated & Medical Facilities & $21 \mathrm{a}$ & \begin{tabular}{|c|} 
Central Steam Air \\
Handling \\
Unit/Electric Air- \\
Cooled Chiller
\end{tabular} & $\begin{array}{l}\text { Open-Loop } \\
\text { GSHP }\end{array}$ & 7.4 & 1.5 & $¥ 3,717,600$ & 29 & $¥ 502,400$ \\
\hline Camp Zama & Appropriated & Medical Facilities & $21 \mathrm{a}$ & \begin{tabular}{|c|} 
Central Steam Air \\
Handling \\
Unit/Electric Air- \\
Cooled Chiller
\end{tabular} & $\begin{array}{c}\text { Open-Loop } \\
\text { GSHP }\end{array}$ & 7.4 & 1.5 & $¥ 4,779,700$ & 38 & $¥ 645,900$ \\
\hline Camp Zama & Appropriated & Post Exchange & $60 d$ & $\begin{array}{c}\text { Central Steam Air } \\
\text { Handling } \\
\text { Unit/Electric } \\
\text { Water-Cooled } \\
\text { Reciprocating } \\
\text { Chiller }\end{array}$ & $\begin{array}{l}\text { Open-Loop } \\
\text { GSHP }\end{array}$ & 7.6 & 1.7 & $¥ 14,285,800$ & 210 & $¥ 1,879,700$ \\
\hline Camp Zama & Alternative & $\begin{array}{c}\text { 1980s Large } \\
\text { Lodging/Barracks }\end{array}$ & 30b-2 & \begin{tabular}{|c|} 
Central Steam Air \\
Handling \\
Unit/Central Steam \\
Air-Cooled \\
Absorption Chiller \\
\end{tabular} & $\begin{array}{c}\text { Vertical } \\
\text { Closed-Loop } \\
\text { GSHP }\end{array}$ & 15.6 & 1.8 & $¥ 35,551,800$ & 2,158 & $¥ 2,279,000$ \\
\hline
\end{tabular}




\begin{tabular}{|c|c|c|c|c|c|c|c|c|c|c|}
\hline Installation & $\begin{array}{l}\text { Funding } \\
\text { Source }\end{array}$ & Description & $\begin{array}{l}\text { Group } \\
\text { ID }\end{array}$ & $\begin{array}{c}\text { Current } \\
\text { Heating/Cooling } \\
\text { Technology }\end{array}$ & $\begin{array}{c}\text { Retrofit } \\
\text { Technology }\end{array}$ & $\begin{array}{c}\text { Payback } \\
\text { Period } \\
\text { (years) }\end{array}$ & $\begin{array}{c}\text { Savings to } \\
\text { Investment } \\
\text { Ratio }\end{array}$ & $\begin{array}{c}\text { Installed } \\
\text { Capital Cost } \\
\text { (¥) }\end{array}$ & $\begin{array}{c}\text { Energy } \\
\text { Savings } \\
\text { (MMBtu/yr) }\end{array}$ & $\begin{array}{c}\text { Cost } \\
\text { Savings } \\
\text { (¥/yr) }\end{array}$ \\
\hline Camp Zama & Alternative & $\begin{array}{c}\text { 1980s Large } \\
\text { Lodging/Barracks }\end{array}$ & $30 b-2$ & \begin{tabular}{|c|} 
Central Steam Air \\
Handling \\
Unit/Central Steam \\
Air-Cooled \\
Absorption Chiller \\
\end{tabular} & $\begin{array}{c}\text { Vertical } \\
\text { Closed-Loop } \\
\text { GSHP }\end{array}$ & 15.6 & 1.8 & $¥ 50,593,000$ & 3,071 & $¥ 3,243,100$ \\
\hline Camp Zama & Appropriated & $\begin{array}{c}\text { 1980s Large } \\
\text { Lodging/Barracks }\end{array}$ & $30 b-2$ & \begin{tabular}{|c|} 
Central Steam Air \\
Handling \\
Unit/Central Steam \\
Air-Cooled \\
Absorption Chiller \\
\end{tabular} & $\begin{array}{c}\text { Vertical } \\
\text { Closed-Loop } \\
\text { GSHP }\end{array}$ & 13.6 & 1.4 & $¥ 35,551,800$ & 2,158 & $¥ 2,614,100$ \\
\hline Camp Zama & Appropriated & $\begin{array}{c}\text { 1980s Large } \\
\text { Lodging/Barracks }\end{array}$ & $30 b-2$ & \begin{tabular}{|c|} 
Central Steam Air \\
Handling \\
Unit/Central Steam \\
Air-Cooled \\
Absorption Chiller \\
\end{tabular} & $\begin{array}{c}\text { Vertical } \\
\text { Closed-Loop } \\
\text { GSHP }\end{array}$ & 13.6 & 1.4 & $¥ 50,593,000$ & 3,071 & $¥ 3,720,100$ \\
\hline Camp Zama & Alternative & $\begin{array}{l}\text { 1990s Family Housing } \\
\text { Single Units }\end{array}$ & 30sf-2 & \begin{tabular}{|c|} 
Central Hot Water \\
Air Handling \\
Unit/Electric \\
Package Unit \\
\end{tabular} & \begin{tabular}{|c} 
Vertical \\
Closed-Loop \\
GSHP \\
\end{tabular} & 17.1 & 1 & $¥ 1,669,100$ & 33 & $¥ 97,600$ \\
\hline Camp Zama & Appropriated & $\begin{array}{l}\text { 1990s Family Housing } \\
\text { Single Units }\end{array}$ & 30sf-2 & \begin{tabular}{|c|} 
Central Hot Water \\
Air Handling \\
Unit/Electric \\
Package Unit \\
\end{tabular} & $\begin{array}{c}\text { Vertical } \\
\text { Closed-Loop } \\
\text { GSHP }\end{array}$ & 14.9 & 1.3 & $¥ 1,669,100$ & 33 & $¥ 112,000$ \\
\hline Camp Zama & Appropriated & MWR Facilities & $80 \mathrm{~b}$ & $\begin{array}{l}\text { Central Steam Air } \\
\text { Handling } \\
\text { Unit/Electric Air- } \\
\text { Cooled Chiller } \\
\end{array}$ & $\begin{array}{c}\text { Vertical } \\
\text { Closed-Loop } \\
\text { GSHP }\end{array}$ & 14.8 & 1.2 & $¥ 22,038,200$ & 247 & $¥ 1,489,100$ \\
\hline Camp Zama & Appropriated & MWR Facilities & $80 \mathrm{~b}$ & $\begin{array}{l}\text { Central Steam Air } \\
\text { Handling } \\
\text { Unit/Electric Air- } \\
\text { Cooled Chiller } \\
\end{array}$ & $\begin{array}{c}\text { Vertical } \\
\text { Closed-Loop } \\
\text { GSHP }\end{array}$ & 14.4 & 1.2 & $¥ 34,434,600$ & 385 & $¥ 2,391,300$ \\
\hline Camp Zama & Appropriated & $\begin{array}{l}\text { 1960s Large Storage } \\
\text { (offices) }\end{array}$ & $40 \mathrm{f}$ & \begin{tabular}{|c|} 
Central Steam Air \\
Handling \\
Unit/Electric \\
Package Unit \\
\end{tabular} & $\begin{array}{c}\text { Vertical } \\
\text { Closed-Loop } \\
\text { GSHP }\end{array}$ & 15.3 & 1.3 & $¥ 2,568,300$ & 30 & $¥ 167,900$ \\
\hline $\begin{array}{c}\text { Sagami } \\
\text { General } \\
\text { Depot }\end{array}$ & Appropriated & $\begin{array}{c}\text { 1950s Small Conditioned } \\
\text { Warehouse }\end{array}$ & $40 \mathrm{~g}$ & $\begin{array}{c}\text { Electric } \\
\text { Conventional } \\
\text { Furnace/Electric } \\
\text { Package Unit } \\
\end{array}$ & $\begin{array}{c}\text { Horizontal } \\
\text { Closed-Loop } \\
\text { GSHP }\end{array}$ & 5.6 & 2.4 & $¥ 19,413,900$ & 214 & $¥ 3,466,800$ \\
\hline
\end{tabular}




\begin{tabular}{|c|c|c|c|c|c|c|c|c|c|c|}
\hline Installation & $\begin{array}{l}\text { Funding } \\
\text { Source }\end{array}$ & Description & $\begin{array}{l}\text { Group } \\
\text { ID }\end{array}$ & $\begin{array}{c}\text { Current } \\
\text { Heating/Cooling } \\
\text { Technology }\end{array}$ & $\begin{array}{c}\text { Retrofit } \\
\text { Technology }\end{array}$ & $\begin{array}{c}\text { Payback } \\
\text { Period } \\
\text { (years) }\end{array}$ & $\begin{array}{c}\text { Savings to } \\
\text { Investment } \\
\text { Ratio }\end{array}$ & $\begin{array}{c}\text { Installed } \\
\text { Capital Cost } \\
\text { (¥) }\end{array}$ & $\begin{array}{c}\text { Energy } \\
\text { Savings } \\
\text { (MMBtu/yr) }\end{array}$ & $\begin{array}{c}\text { Cost } \\
\text { Savings } \\
\text { (¥/yr) }\end{array}$ \\
\hline $\begin{array}{c}\text { Sagami } \\
\text { General } \\
\text { Depot }\end{array}$ & Appropriated & 1980s School/Admin & $10 \mathrm{~d}$ & $\begin{array}{c}\text { Electric } \\
\text { Conventional } \\
\text { Furnace/Electric } \\
\text { Package Unit }\end{array}$ & $\begin{array}{l}\text { Horizontal } \\
\text { Closed-Loop } \\
\text { GSHP }\end{array}$ & 7.6 & 1.9 & $¥ 10,809,500$ & 27 & $¥ 1,422,300$ \\
\hline $\begin{array}{c}\text { Sagami } \\
\text { General } \\
\text { Depot }\end{array}$ & Alternative & $\begin{array}{l}\text { 1990s Medium Conditioned } \\
\text { Warehouse }\end{array}$ & $40 \mathrm{e}$ & $\begin{array}{l}\text { Central Steam Air } \\
\text { Handling } \\
\text { Unit/Electric Air- } \\
\text { Cooled Chiller }\end{array}$ & $\begin{array}{l}\text { Horizontal } \\
\text { Closed-Loop } \\
\text { GSHP }\end{array}$ & 11 & 1.1 & $¥ 83,033,900$ & 761 & $¥ 7,548,500$ \\
\hline $\begin{array}{c}\text { Sagami } \\
\text { General } \\
\text { Depot }\end{array}$ & Appropriated & $\begin{array}{c}\text { 1990s Medium Conditioned } \\
\text { Warehouse }\end{array}$ & $40 \mathrm{e}$ & $\begin{array}{l}\text { Central Steam Air } \\
\text { Handling } \\
\text { Unit/Electric Air- } \\
\text { Cooled Chiller }\end{array}$ & $\begin{array}{l}\text { Horizontal } \\
\text { Closed-Loop } \\
\text { GSHP }\end{array}$ & 11.2 & 1.4 & $¥ 83,033,900$ & 761 & $¥ 7,413,700$ \\
\hline $\begin{array}{c}\text { Sagami } \\
\text { General } \\
\text { Depot }\end{array}$ & Appropriated & $\begin{array}{c}\text { 1990s Medium Conditioned } \\
\text { Warehouse }\end{array}$ & $40 \mathrm{e}$ & $\begin{array}{l}\text { Central Steam Air } \\
\text { Handling } \\
\text { Unit/Electric Air- } \\
\text { Cooled Chiller }\end{array}$ & $\begin{array}{l}\text { Horizontal } \\
\text { Closed-Loop } \\
\text { GSHP }\end{array}$ & 11.5 & 1.4 & $¥ 33,915,300$ & 311 & $¥ 2,949,200$ \\
\hline $\begin{array}{c}\text { Sagami } \\
\text { General } \\
\text { Depot }\end{array}$ & Alternative & $\begin{array}{l}\text { 1950s Small Conditioned } \\
\text { Warehouse }\end{array}$ & $40 \mathrm{~g}$ & $\begin{array}{c}\text { Electric } \\
\text { Conventional } \\
\text { Furnace/Electric } \\
\text { Package Unit } \\
\end{array}$ & $\begin{array}{l}\text { Open-Loop } \\
\text { GSHP }\end{array}$ & 6.7 & 1.3 & $¥ 31,931,700$ & 253 & $¥ 4,765,900$ \\
\hline $\begin{array}{c}\text { Sagami } \\
\text { General } \\
\text { Depot }\end{array}$ & Appropriated & $\begin{array}{l}\text { 1950s Small Conditioned } \\
\text { Warehouse }\end{array}$ & $40 \mathrm{~g}$ & $\begin{array}{c}\text { Electric } \\
\text { Conventional } \\
\text { Furnace/Electric } \\
\text { Package Unit } \\
\end{array}$ & $\begin{array}{l}\text { Open-Loop } \\
\text { GSHP }\end{array}$ & 6.4 & 1.9 & $¥ 31,931,700$ & 253 & $¥ 4,989,300$ \\
\hline $\begin{array}{c}\text { Sagami } \\
\text { General } \\
\text { Depot }\end{array}$ & Alternative & $\begin{array}{c}\text { 1990s Medium Conditioned } \\
\text { Warehouse }\end{array}$ & $40 \mathrm{e}$ & $\begin{array}{c}\text { Central Steam Air } \\
\text { Handling } \\
\text { Unit/Electric Air- } \\
\text { Cooled Chiller } \\
\end{array}$ & $\begin{array}{l}\text { Open-Loop } \\
\text { GSHP }\end{array}$ & 5.2 & 2.1 & $¥ 58,332,500$ & 893 & $¥ 11,217,800$ \\
\hline $\begin{array}{c}\text { Sagami } \\
\text { General } \\
\text { Depot }\end{array}$ & Alternative & $\begin{array}{c}\text { 1990s Medium Conditioned } \\
\text { Warehouse }\end{array}$ & $40 \mathrm{e}$ & $\begin{array}{l}\text { Central Steam Air } \\
\text { Handling } \\
\text { Unit/Electric Air- } \\
\text { Cooled Chiller }\end{array}$ & $\begin{array}{l}\text { Open-Loop } \\
\text { GSHP }\end{array}$ & 5.2 & 2.1 & $¥ 23,825,900$ & 365 & $¥ 4,581,900$ \\
\hline $\begin{array}{c}\text { Sagami } \\
\text { General } \\
\text { Depot }\end{array}$ & Appropriated & $\begin{array}{c}\text { 1990s Medium Conditioned } \\
\text { Warehouse }\end{array}$ & $40 \mathrm{e}$ & $\begin{array}{c}\text { Central Steam Air } \\
\text { Handling } \\
\text { Unit/Electric Air- } \\
\text { Cooled Chiller }\end{array}$ & $\begin{array}{l}\text { Open-Loop } \\
\text { GSHP }\end{array}$ & 4.6 & 3 & $¥ 58,332,500$ & 893 & $¥ 12,681,000$ \\
\hline $\begin{array}{c}\text { Sagami } \\
\text { General } \\
\text { Depot }\end{array}$ & Appropriated & $\begin{array}{l}\text { 1990s Medium Conditioned } \\
\text { Warehouse }\end{array}$ & $40 \mathrm{e}$ & $\begin{array}{l}\text { Central Steam Air } \\
\text { Handling } \\
\text { Unit/Electric Air- } \\
\text { Cooled Chiller }\end{array}$ & $\begin{array}{l}\text { Open-Loop } \\
\text { GSHP }\end{array}$ & 4.6 & 3 & $¥ 23,825,900$ & 365 & $¥ 5,179,500$ \\
\hline
\end{tabular}




\begin{tabular}{|c|c|c|c|c|c|c|c|c|c|c|}
\hline Installation & $\begin{array}{l}\text { Funding } \\
\text { Source }\end{array}$ & Description & $\begin{array}{l}\text { Group } \\
\text { ID }\end{array}$ & $\begin{array}{c}\text { Current } \\
\text { Heating/Cooling } \\
\text { Technology }\end{array}$ & $\begin{array}{c}\text { Retrofit } \\
\text { Technology }\end{array}$ & $\begin{array}{c}\text { Payback } \\
\text { Period } \\
\text { (years) }\end{array}$ & $\begin{array}{c}\text { Savings to } \\
\text { Investment } \\
\text { Ratio }\end{array}$ & $\begin{array}{c}\text { Installed } \\
\text { Capital Cost } \\
\text { (¥) }\end{array}$ & $\begin{array}{c}\text { Energy } \\
\text { Savings } \\
\text { (MMBtu/yr) }\end{array}$ & $\begin{array}{c}\text { Cost } \\
\text { Savings } \\
(¥ / \mathbf{y r})\end{array}$ \\
\hline $\begin{array}{c}\text { Sagami } \\
\text { General } \\
\text { Depot }\end{array}$ & Alternative & $\begin{array}{c}\text { 2000s Large } \\
\text { Utility/Maintenance }\end{array}$ & $60 a$ & $\begin{array}{c}\text { Central Steam Air } \\
\text { Handling } \\
\text { Unit/Electric } \\
\text { Package Unit }\end{array}$ & $\begin{array}{l}\text { Open-Loop } \\
\text { GSHP }\end{array}$ & 8.4 & 1.4 & $¥ 9,925,700$ & 236 & $¥ 1,181,600$ \\
\hline $\begin{array}{c}\text { Sagami } \\
\text { General } \\
\text { Depot }\end{array}$ & Alternative & $\begin{array}{l}\text { 2000s Large } \\
\text { Utility/Maintenance }\end{array}$ & $60 a$ & $\begin{array}{c}\text { Central Steam Air } \\
\text { Handling } \\
\text { Unit/Electric } \\
\text { Package Unit }\end{array}$ & $\begin{array}{l}\text { Open-Loop } \\
\text { GSHP }\end{array}$ & 7 & 1.7 & $¥ 6,422,500$ & 158 & $¥ 917,500$ \\
\hline $\begin{array}{c}\text { Sagami } \\
\text { General } \\
\text { Depot }\end{array}$ & Alternative & $\begin{array}{l}\text { 2000s Large } \\
\text { Utility/Maintenance }\end{array}$ & $60 \mathrm{a}$ & $\begin{array}{c}\text { Central Steam Air } \\
\text { Handling } \\
\text { Unit/Electric } \\
\text { Package Unit }\end{array}$ & $\begin{array}{l}\text { Open-Loop } \\
\text { GSHP }\end{array}$ & 7.4 & 1.6 & $¥ 7,006,400$ & 172 & $¥ 946,800$ \\
\hline $\begin{array}{c}\text { Sagami } \\
\text { General } \\
\text { Depot }\end{array}$ & Appropriated & $\begin{array}{l}\text { 2000s Large } \\
\text { Utility/Maintenance }\end{array}$ & $60 a$ & $\begin{array}{c}\text { Central Steam Air } \\
\text { Handling } \\
\text { Unit/Electric } \\
\text { Package Unit }\end{array}$ & $\begin{array}{l}\text { Open-Loop } \\
\text { GSHP }\end{array}$ & 7.5 & 2 & $¥ 9,925,700$ & 236 & $¥ 1,323,400$ \\
\hline $\begin{array}{c}\text { Sagami } \\
\text { General } \\
\text { Depot }\end{array}$ & Appropriated & $\begin{array}{l}\text { 2000s Large } \\
\text { Utility/Maintenance }\end{array}$ & $60 a$ & $\begin{array}{c}\text { Central Steam Air } \\
\text { Handling } \\
\text { Unit/Electric } \\
\text { Package Unit } \\
\end{array}$ & $\begin{array}{l}\text { Open-Loop } \\
\text { GSHP }\end{array}$ & 6.3 & 2.4 & $¥ 6,422,500$ & 158 & $¥ 1,019,400$ \\
\hline $\begin{array}{c}\text { Sagami } \\
\text { General } \\
\text { Depot }\end{array}$ & Appropriated & $\begin{array}{l}\text { 2000s Large } \\
\text { Utility/Maintenance }\end{array}$ & $60 a$ & $\begin{array}{c}\text { Central Steam Air } \\
\text { Handling } \\
\text { Unit/Electric } \\
\text { Package Unit } \\
\end{array}$ & $\begin{array}{l}\text { Open-Loop } \\
\text { GSHP }\end{array}$ & 6.5 & 2.2 & $¥ 7,006,400$ & 172 & $¥ 1,077,900$ \\
\hline $\begin{array}{c}\text { Sagami } \\
\text { General } \\
\text { Depot }\end{array}$ & Alternative & $\begin{array}{c}\text { 1950s Small Conditioned } \\
\text { Warehouse }\end{array}$ & $40 \mathrm{~g}$ & $\begin{array}{c}\text { Electric } \\
\text { Conventional } \\
\text { Furnace/Electric } \\
\text { Package Unit } \\
\end{array}$ & $\begin{array}{l}\text { Vertical } \\
\text { Closed-Loop } \\
\text { GSHP }\end{array}$ & 5.1 & 1.9 & $¥ 16,913,400$ & 218 & $¥ 3,316,400$ \\
\hline $\begin{array}{c}\text { Sagami } \\
\text { General } \\
\text { Depot }\end{array}$ & Appropriated & $\begin{array}{c}\text { 1950s Small Conditioned } \\
\text { Warehouse }\end{array}$ & $40 \mathrm{~g}$ & $\begin{array}{c}\text { Electric } \\
\text { Conventional } \\
\text { Furnace/Electric } \\
\text { Package Unit }\end{array}$ & $\begin{array}{c}\text { Vertical } \\
\text { Closed-Loop } \\
\text { GSHP }\end{array}$ & 4.8 & 2.7 & $¥ 16,913,400$ & 218 & $¥ 3,523,600$ \\
\hline $\begin{array}{c}\text { Sagami } \\
\text { General } \\
\text { Depot }\end{array}$ & Alternative & 1980s School/Admin & $10 \mathrm{~d}$ & $\begin{array}{c}\text { Electric } \\
\text { Conventional } \\
\text { Furnace/Electric } \\
\text { Package Unit }\end{array}$ & $\begin{array}{l}\text { Vertical } \\
\text { Closed-Loop } \\
\text { GSHP }\end{array}$ & 8.2 & 1.3 & $¥ 11,214,100$ & 35 & $¥ 1,367,600$ \\
\hline $\begin{array}{c}\text { Sagami } \\
\text { General } \\
\text { Depot }\end{array}$ & Appropriated & 1980s School/Admin & $10 \mathrm{~d}$ & $\begin{array}{c}\text { Electric } \\
\text { Conventional } \\
\text { Furnace/Electric } \\
\text { Package Unit }\end{array}$ & $\begin{array}{c}\text { Vertical } \\
\text { Closed-Loop } \\
\text { GSHP }\end{array}$ & 7.5 & 1.9 & $¥ 11,214,100$ & 35 & $¥ 1,495,200$ \\
\hline
\end{tabular}




\begin{tabular}{|c|c|c|c|c|c|c|c|c|c|c|}
\hline Installation & $\begin{array}{l}\text { Funding } \\
\text { Source }\end{array}$ & Description & $\begin{array}{l}\text { Group } \\
\text { ID }\end{array}$ & $\begin{array}{c}\text { Current } \\
\text { Heating/Cooling } \\
\text { Technology }\end{array}$ & $\begin{array}{c}\text { Retrofit } \\
\text { Technology }\end{array}$ & $\begin{array}{c}\text { Payback } \\
\text { Period } \\
\text { (years) }\end{array}$ & $\begin{array}{c}\text { Savings to } \\
\text { Investment } \\
\text { Ratio }\end{array}$ & $\begin{array}{c}\text { Installed } \\
\text { Capital Cost } \\
(¥)\end{array}$ & $\begin{array}{c}\text { Energy } \\
\text { Savings } \\
\text { (MMBtu/yr) }\end{array}$ & $\begin{array}{c}\text { Cost } \\
\text { Savings } \\
\text { (¥/yr) }\end{array}$ \\
\hline $\begin{array}{c}\text { Sagami } \\
\text { General } \\
\text { Depot }\end{array}$ & Alternative & $\begin{array}{l}\text { 1990s Medium Conditioned } \\
\text { Warehouse }\end{array}$ & $40 \mathrm{e}$ & $\begin{array}{l}\text { Central Steam Air } \\
\text { Handling } \\
\text { Unit/Electric Air- } \\
\text { Cooled Chiller } \\
\end{array}$ & $\begin{array}{c}\text { Vertical } \\
\text { Closed-Loop } \\
\text { GSHP }\end{array}$ & 6.5 & 1.9 & $¥ 61,811,300$ & 803 & $¥ 9,509,400$ \\
\hline $\begin{array}{l}\text { Sagami } \\
\text { General } \\
\text { Depot }\end{array}$ & Alternative & $\begin{array}{l}\text { 1990s Medium Conditioned } \\
\text { Warehouse }\end{array}$ & $40 \mathrm{e}$ & $\begin{array}{l}\text { Central Steam Air } \\
\text { Handling } \\
\text { Unit/Electric Air- } \\
\text { Cooled Chiller } \\
\end{array}$ & $\begin{array}{c}\text { Vertical } \\
\text { Closed-Loop } \\
\text { GSHP }\end{array}$ & 9 & 1.4 & $¥ 25,246,900$ & 328 & $¥ 2,805,200$ \\
\hline $\begin{array}{l}\text { Sagami } \\
\text { General } \\
\text { Depot }\end{array}$ & Appropriated & $\begin{array}{l}\text { 1990s Medium Conditioned } \\
\text { Warehouse }\end{array}$ & $40 \mathrm{e}$ & $\begin{array}{l}\text { Central Steam Air } \\
\text { Handling } \\
\text { Unit/Electric Air- } \\
\text { Cooled Chiller } \\
\end{array}$ & $\begin{array}{c}\text { Vertical } \\
\text { Closed-Loop } \\
\text { GSHP }\end{array}$ & 5.3 & 2.9 & $¥ 61,811,300$ & 803 & $¥ 11,662,500$ \\
\hline $\begin{array}{l}\text { Sagami } \\
\text { General } \\
\text { Depot }\end{array}$ & Appropriated & $\begin{array}{l}\text { 1990s Medium Conditioned } \\
\text { Warehouse }\end{array}$ & $40 \mathrm{e}$ & $\begin{array}{l}\text { Central Steam Air } \\
\text { Handling } \\
\text { Unit/Electric Air- } \\
\text { Cooled Chiller } \\
\end{array}$ & $\begin{array}{c}\text { Vertical } \\
\text { Closed-Loop } \\
\text { GSHP }\end{array}$ & 5.8 & 2.6 & $¥ 25,246,900$ & 328 & $¥ 4,352,900$ \\
\hline $\begin{array}{c}\text { Sagamihara } \\
\text { Family } \\
\text { Housing } \\
\text { Area } \\
\end{array}$ & Appropriated & Access Control Facilities & $10 \mathrm{i}$ & \begin{tabular}{|c|} 
Electric Air Source \\
Heat Pump/Electric \\
Air Source Heat \\
Pump \\
\end{tabular} & $\begin{array}{l}\text { Horizontal } \\
\text { Closed-Loop } \\
\text { GSHP }\end{array}$ & 8.4 & 1.4 & $¥ 835,900$ & 0 & $¥ 99,500$ \\
\hline $\begin{array}{c}\text { Sagamihara } \\
\text { Family } \\
\text { Housing } \\
\text { Area } \\
\end{array}$ & Appropriated & $\begin{array}{l}\text { 1950s Family Housing } \\
\text { Quad Units }\end{array}$ & 30sf-5 & \begin{tabular}{|c|} 
Electric Air Source \\
Heat Pump/Electric \\
Air Source Heat \\
Pump \\
\end{tabular} & $\begin{array}{l}\text { Open-Loop } \\
\text { GSHP }\end{array}$ & 6.9 & 1.8 & $¥ 109,936,100$ & 121 & $¥ 15,932,800$ \\
\hline $\begin{array}{c}\text { Sagamihara } \\
\text { Family } \\
\text { Housing } \\
\text { Area } \\
\end{array}$ & Appropriated & $\begin{array}{l}\text { 1950s Family Housing } \\
\text { Triple Units }\end{array}$ & 30sf-4 & \begin{tabular}{|c|} 
Electric Air Source \\
Heat Pump/Electric \\
Air Source Heat \\
Pump \\
\end{tabular} & $\begin{array}{l}\text { Open-Loop } \\
\text { GSHP }\end{array}$ & 7.5 & 1.7 & $¥ 141,688,700$ & 52 & $¥ 18,891,800$ \\
\hline $\begin{array}{c}\text { Sagamihara } \\
\text { Family } \\
\text { Housing } \\
\text { Area } \\
\end{array}$ & Appropriated & 1980s School/Admin & $10 f$ & \begin{tabular}{|c|} 
Electric Air Source \\
Heat Pump/Electric \\
Air Source Heat \\
Pump \\
\end{tabular} & $\begin{array}{l}\text { Open-Loop } \\
\text { GSHP }\end{array}$ & 5.5 & 4 & $¥ 15,853,300$ & -49 & $¥ 2,882,400$ \\
\hline \begin{tabular}{c|} 
Sagamihara \\
Family \\
Housing \\
Area \\
\end{tabular} & Appropriated & $\begin{array}{c}\text { Exchange/Emergency } \\
\text { Facilities }\end{array}$ & $10 d$ & \begin{tabular}{|c|} 
Electric Air Source \\
Heat Pump/Electric \\
Air Source Heat \\
Pump \\
\end{tabular} & $\begin{array}{l}\text { Open-Loop } \\
\text { GSHP }\end{array}$ & 21.2 & 2.1 & $¥ 8,317,300$ & 13 & $¥ 392,300$ \\
\hline $\begin{array}{c}\text { Sagamihara } \\
\text { Family } \\
\text { Housing } \\
\text { Area } \\
\end{array}$ & Appropriated & Access Control Facilities & $10 \mathrm{i}$ & \begin{tabular}{|c|} 
Electric Air Source \\
Heat Pump/Electric \\
Air Source Heat \\
Pump \\
\end{tabular} & $\begin{array}{c}\text { Vertical } \\
\text { Closed-Loop } \\
\text { GSHP }\end{array}$ & 9.7 & 1.3 & $¥ 1,349,200$ & 1 & $¥ 139,100$ \\
\hline
\end{tabular}




\begin{tabular}{|c|c|c|c|c|c|c|c|c|c|c|}
\hline Installation & $\begin{array}{l}\text { Funding } \\
\text { Source }\end{array}$ & Description & $\begin{array}{l}\text { Group } \\
\text { ID }\end{array}$ & $\begin{array}{c}\text { Current } \\
\text { Heating/Cooling } \\
\text { Technology }\end{array}$ & $\begin{array}{c}\text { Retrofit } \\
\text { Technology }\end{array}$ & $\begin{array}{c}\text { Payback } \\
\text { Period } \\
\text { (years) }\end{array}$ & $\begin{array}{c}\text { Savings to } \\
\text { Investment } \\
\text { Ratio }\end{array}$ & $\begin{array}{c}\text { Installed } \\
\text { Capital Cost } \\
(¥)\end{array}$ & $\begin{array}{c}\text { Energy } \\
\text { Savings } \\
\text { (MMBtu/yr) }\end{array}$ & $\begin{array}{c}\text { Cost } \\
\text { Savings } \\
\text { (¥/yr) }\end{array}$ \\
\hline $\begin{array}{l}\text { Yokohama } \\
\text { North Dock }\end{array}$ & Alternative & Access Control Facilities & $10 \mathrm{i}$ & $\begin{array}{c}\text { Electric } \\
\text { Conventional } \\
\text { Furnace/Electric } \\
\text { Package Unit } \\
\end{array}$ & $\begin{array}{l}\text { Horizontal } \\
\text { Closed-Loop } \\
\text { GSHP }\end{array}$ & 7 & 1.4 & $¥ 1,320,000$ & 45 & $¥ 188,600$ \\
\hline $\begin{array}{l}\text { Yokohama } \\
\text { North Dock }\end{array}$ & Appropriated & Access Control Facilities & $10 \mathrm{i}$ & $\begin{array}{c}\text { Electric } \\
\text { Conventional } \\
\text { Furnace/Electric } \\
\text { Package Unit } \\
\end{array}$ & $\begin{array}{l}\text { Horizontal } \\
\text { Closed-Loop } \\
\text { GSHP }\end{array}$ & 6.4 & 2.2 & $¥ 1,320,000$ & 45 & $¥ 206,300$ \\
\hline $\begin{array}{l}\text { Yokohama } \\
\text { North Dock }\end{array}$ & Appropriated & $\begin{array}{c}\text { Exchange/Emergency } \\
\text { Facilities }\end{array}$ & $60 \mathrm{a}$ & $\begin{array}{c}\text { Central Steam } \\
\text { Radiator/Electric } \\
\text { Package Unit } \\
\end{array}$ & $\begin{array}{c}\text { Horizontal } \\
\text { Closed-Loop } \\
\text { GSHP } \\
\end{array}$ & 13.7 & 1 & $¥ 14,120,400$ & 157 & $¥ 1,030,700$ \\
\hline $\begin{array}{l}\text { Yokohama } \\
\text { North Dock }\end{array}$ & Alternative & $\begin{array}{c}\text { Exchange/Emergency } \\
\text { Facilities }\end{array}$ & $60 \mathrm{a}$ & $\begin{array}{c}\text { Central Steam } \\
\text { Radiator/Electric } \\
\text { Package Unit } \\
\end{array}$ & $\begin{array}{l}\text { Open-Loop } \\
\text { GSHP }\end{array}$ & 8 & 1.2 & $¥ 10,849,000$ & 174 & $¥ 1,356,100$ \\
\hline $\begin{array}{l}\text { Yokohama } \\
\text { North Dock }\end{array}$ & Appropriated & $\begin{array}{c}\text { Exchange/Emergency } \\
\text { Facilities }\end{array}$ & 60a & $\begin{array}{c}\text { Central Steam } \\
\text { Radiator/Electric } \\
\text { Package Unit } \\
\end{array}$ & $\begin{array}{l}\text { Open-Loop } \\
\text { GSHP }\end{array}$ & 7 & 1.8 & $¥ 10,849,000$ & 174 & $¥ 1,549,900$ \\
\hline $\begin{array}{l}\text { Yokohama } \\
\text { North Dock }\end{array}$ & Alternative & Access Control Facilities & $10 \mathrm{i}$ & $\begin{array}{c}\text { Electric } \\
\text { Conventional } \\
\text { Furnace/Electric } \\
\text { Package Unit }\end{array}$ & $\begin{array}{c}\text { Vertical } \\
\text { Closed-Loop } \\
\text { GSHP }\end{array}$ & 9.1 & 1.1 & $¥ 1,995,900$ & 47 & $¥ 219,300$ \\
\hline $\begin{array}{l}\text { Yokohama } \\
\text { North Dock }\end{array}$ & Appropriated & Access Control Facilities & $10 \mathrm{i}$ & $\begin{array}{c}\text { Electric } \\
\text { Conventional } \\
\text { Furnace/Electric } \\
\text { Package Unit } \\
\end{array}$ & $\begin{array}{c}\text { Vertical } \\
\text { Closed-Loop } \\
\text { GSHP }\end{array}$ & 8.4 & 1.6 & $¥ 1,995,900$ & 47 & $¥ 237,600$ \\
\hline $\begin{array}{l}\text { Yokohama } \\
\text { North Dock }\end{array}$ & Alternative & $\begin{array}{c}\text { Exchange/Emergency } \\
\text { Facilities }\end{array}$ & $60 \mathrm{a}$ & $\begin{array}{c}\text { Central Steam } \\
\text { Radiator/Electric } \\
\text { Package Unit }\end{array}$ & $\begin{array}{c}\text { Vertical } \\
\text { Closed-Loop } \\
\text { GSHP } \\
\end{array}$ & 10.5 & 1 & $¥ 13,155,200$ & 168 & $¥ 1,252,900$ \\
\hline $\begin{array}{l}\text { Yokohama } \\
\text { North Dock }\end{array}$ & Appropriated & $\begin{array}{c}\text { Exchange/Emergency } \\
\text { Facilities }\end{array}$ & $60 \mathrm{a}$ & $\begin{array}{c}\text { Central Steam } \\
\text { Radiator/Electric } \\
\text { Package Unit } \\
\end{array}$ & \begin{tabular}{|c|} 
Vertical \\
Closed-Loop \\
GSHP \\
\end{tabular} & 9.2 & 1.6 & $¥ 13,155,200$ & 168 & $¥ 1,429,900$ \\
\hline
\end{tabular}





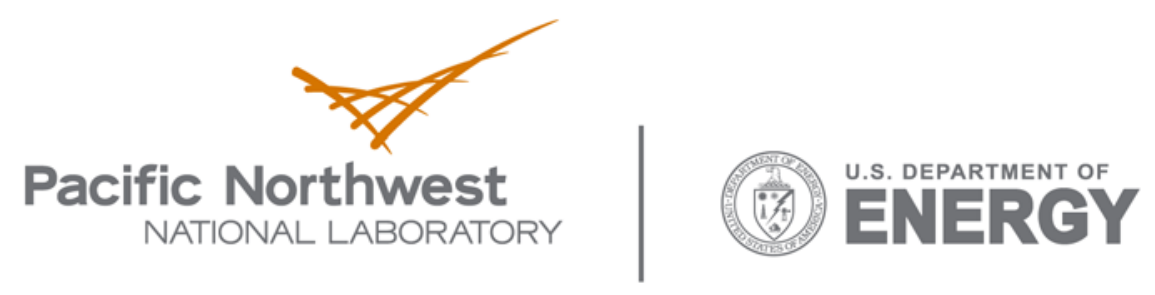

902 Battelle Boulevard

P.O. Box 999

Richland, WA 99352

1-888-375-PNNL (7665)

www.pnl.gov 